\title{
Impacts of acid deposition, ozone exposure and weather conditions on forest ecosystems in Europe: an overview
}

\author{
W. de Vries • M. H. Dobbertin • S. Solberg • \\ H. F. van Dobben $\cdot$ M. Schaub
}

Received: 19 July 2013 / Accepted: 6 February 2014 / Published online: 1 March 2014

(C) Springer International Publishing Switzerland 2014

\begin{abstract}
Background In 1994, a "Pan-European Programme for Intensive and Continuous Monitoring of Forest Ecosystems" started to contribute to a better understanding of the impact of air pollution, climate change and natural stress factors on forest ecosystems. The programme today counts approximately 760 permanent observation plots including near 500 plots with data on both air quality and forest ecosystem impacts.

Scope This paper first presents impacts of air pollution and climate on forests ecosystems as reported in the literature on the basis of laboratory and field
\end{abstract}

Matthias Dobbertin in precious memory

Responsible Editor: Philippe Hinsinger.

W. de Vries $(\bowtie) \cdot$ H. F. van Dobben

Alterra, Wageningen University and Research Centre,

P.O. Box 47, Droevendaalse Steeg 4, 6700 AA Wageningen,

The Netherlands

e-mail: wim.devries@wur.nl

\section{W. de Vries}

Environmental Systems Analysis Group, Wageningen University, PO Box 47, 6700 AA Wageningen, The

Netherlands

M. H. Dobbertin · M. Schaub

Swiss Federal Institute for Forest, Snow and Landscape

Research WSL, Zürcherstrasse 111, 8903 Birmensdorf,

Switzerland

S. Solberg

Norwegian Forest and Landscape Institute, P.O. Box 115,

1431 Ås, Norway research. Next, results from monitoring studies, both at a European wide scale and related national studies, are presented in terms of trends and geographic variations in nitrogen and sulphur deposition and ozone concentrations and the impacts of those changes in interaction with weather conditions on (i) water and element budgets and nutrient-acidity status, (ii) forest crown condition, (iii) forest growth and carbon sequestration and (iv) species diversity of the ground vegetation. The empirical, field based forest responses to the various drivers are evaluated in view of available knowledge.

Conclusions Analyses of large scale monitoring data sets show significant effects of atmospheric deposition on nutrient-acidity status in terms of elevated nitrogen and sulphur or sulphate concentrations in forest foliage and soil solution and related soil acidification in terms of elevated aluminium and/or base cation leaching from the forest ecosystem. Relationships of air pollution with crown condition, however, appear to be weak and limited in time and space, while climatic factors appear to be more important drivers. Regarding forest growth, monitoring results indicate a clear fertilization effect of $\mathrm{N}$ deposition on European forests but the field evidence for impacts of ambient ozone exposure on tree growth is less clear.

Keywords Nitrogen deposition - Climate change . Ozone exposure $\cdot$ Monitoring $\cdot$ Element budgets . Forest condition · Forest growth · Ground vegetation 


\section{Introduction}

Trends in environmental conditions in Europe

Environmental conditions are rapidly changing on a global scale since the beginning of the industrial times (Schöpp et al. 2003; IPCC 2007). The human development has not only altered the chemical composition of the atmosphere, but also of water bodies, soils, flora and fauna. Since the late 19th century until its peak in the mid-1980s, sulphur (S) emissions in Europe increased by a factor of seven, while nitrogen $(\mathrm{N})$ emissions increased by a factor near five, correlated with a similar increase in acid deposition (Schöpp et al. 2003). The initial concern for negative effects of acid deposition started in Scandinavia in the seventies, in particular in south Norway, where slow weathering bedrocks and shallow soils made the ecosystems sensitive, and widespread death of trout and salmon was attributed to the enhanced leaking of aluminium (Al) which damaged gills (Baker and Schofield 1982). Low $\mathrm{pH}$ and increased Al levels cause chronic stress can also lead to lower body weight and smaller size and makes fish less able to compete for food and habitat (Lien et al. 1996). Shortly afterwards, in the beginning of the eighties, the health and vitality of forest ecosystems became a subject of wide public and political concern due to the extensive forest damage observed in rural areas in Central Europe, which was connected to air pollution and acid deposition (e.g Schütt et al. 1983; Lammel 1984). The extensive forest damage observed in rural areas in Central Europe in the beginning of the 1980's (e.g. Schütt et al. 1983; Lammel 1984) was in particular the case for the Ore Mountains on the border between Germany, Poland and the Czech Republic, which were heavily exposed to sulphur dioxide $\left(\mathrm{SO}_{2}\right)$.

Of more recent concern are the increasing concentrations of tropospheric ozone $\left(\mathrm{O}_{3}\right)$, which is not only a greenhouse gas with the third strongest radiative forcing on climate (Forster et al. 2007), but is also the air pollutant considered to be causing the most damage to plants in Europe and the US today (Ashmore 2005; Karnosky et al. 2007a; Matyssek et al. 2007b). Tropospheric $\mathrm{O}_{3}$ pollution has shifted from a regional to a global issue because of its intercontinental transport (Derwent et al. 2004; Vingarzan 2004). In fact, tropospheric $\mathrm{O}_{3}$ has been recognized as an important factor within "global change" (IPCC 2001; Ashmore 2005), that has the capacity of reducing carbon sink strength of forest ecosystems (e.g. Karnosky et al. 2003; Sitch et al. 2007; Pretzsch et al. 2010) and modify metabolic responses under elevated atmospheric $\mathrm{CO}_{2}$ (Karnosky et al. 2007b; Matyssek et al. 2010a). Emissions associated with fossil fuel and biomass burning have acted to approximately double the global mean tropospheric $\mathrm{O}_{3}$ concentration (Gauss et al. 2006), and further increases are expected over the twenty-first century (Gauss et al. 2003; IPCC 2007). However, major uncertainties in modelled $\mathrm{O}_{3}$ response exist, mainly due to changes in methane (Wild et al. 2012). Trend analyses of $\mathrm{O}_{3}$ measurements are mainly restricted to northern and western parts of Europe. Overviews of reported trends are given in several publications, such as Monks et al. (2003) and Mol et al. (2010). The temporal trends in tropospheric $\mathrm{O}_{3}$ do not show a uniform picture, apart from sites at the western coast of Europe which are measuring background values. Most sites show a substantial downward trend in peak $\mathrm{O}_{3}$ concentrations (98 and 95 percentiles) over the past 10 to 15 years, which is due to European abatement on nitrogen oxides and volatile organic compound emissions. However, despite this downward trend in peak $\mathrm{O}_{3}$ concentrations, there has been a slight increase in the accumulated dose over a threshold of 40 ppb (AOT40; Fuhrer et al. 1997) in rural stations (Fiala et al. 2003).

Another more recent concern is the rise in $\mathrm{CO}_{2}$ concentrations by $15 \%$ since the late $19^{\text {th }}$ century. Over the 20th century, this has been accompanied by an increase in global average surface temperature by 0.6 $\pm 0.2^{\circ} \mathrm{C}$ (IPCC 2007) and it is expected to increase by 1.4 to $5.8{ }^{\circ} \mathrm{C}$ until 2100 (IPCC 2007). While past temperature change was most pronounced in winter months, current temperature increases in Europe also include spring and summer temperatures (Rebetez and Reinhard 2008). In the European Alps, temperature has increased by more than twice the global average in the 20th century (Christensen and Christensen 2003). Most of this increase has occurred during the last 20 years (Rebetez and Reinhard 2008). For future precipitation, an increase in extreme events is predicted (Christensen and Christensen 2003; Frei et al. 2006), while more hot spells are expected in summer due to increasing variability in temperature (Schär et al. 2004).

A comparison of estimated trends in $\mathrm{S}$ and $\mathrm{N}$ emission, $\mathrm{CO}_{2}$ concentration and temperature for Europe between 1880 and 2005 is shown in Fig. 1. It illustrates why $\mathrm{S}$ emission was of highest concern in the early 1980s. By that time, S emission had increased by 


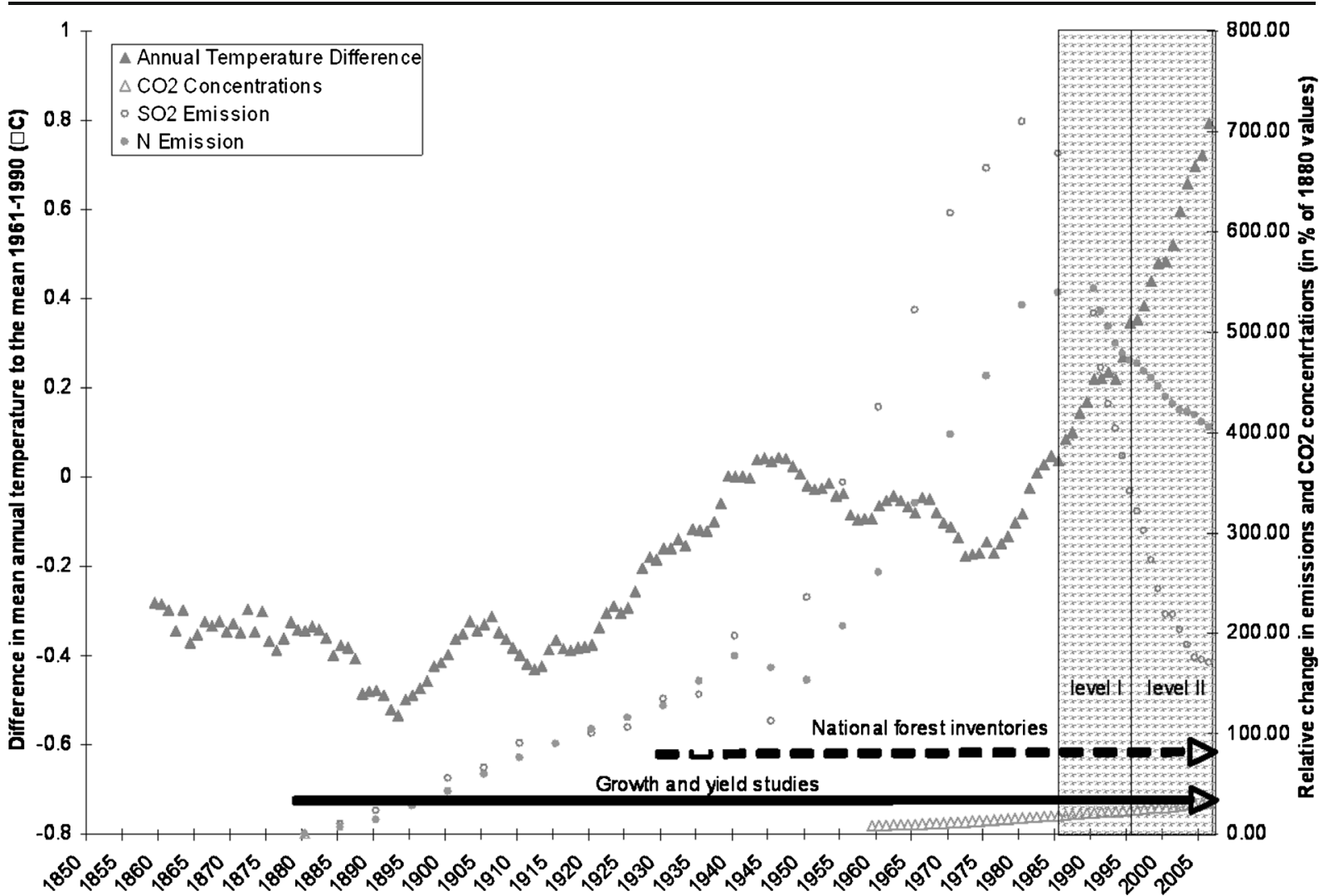

Fig. 1 Relative changes in: (i) $\mathrm{SO}_{2}$ and $\mathrm{N}$ emissions in Europe between 1880 and 2007 (data until 1990 based on (Schöpp et al. 2003) and EEA data from 1990-2007), (ii) $\mathrm{CO}_{2}$ concentrations since 1960 (station Mauna Loa) in comparison to estimated values from 18801880 base $292 \mathrm{ppm}$ and (iii) mean annual temperature

$700 \%$ of the pre-industrial time and total $\mathrm{N}$ emission by roughly $540 \% . \mathrm{CO}_{2}$ concentrations had risen by $18 \%$ and temperature by $0.4{ }^{\circ} \mathrm{C}$. Since then, $\mathrm{S}$ and $\mathrm{N}$ emissions have declined whereas $\mathrm{CO}_{2}$ and temperature is constantly rising, causing an increasing interest in climate change impacts on forest ecosystems.

Impacts of air quality and acid deposition on forest ecosystems

Forest condition is influenced by a multitude of stress factors, including air pollution and climatic factors. The hypotheses on air pollution, which have been subject to considerable controversy over the years (Skelly and Innes 1994), include direct, aboveground impacts of sulphur dioxide $\left(\mathrm{SO}_{2}\right)$ and ozone $\left(\mathrm{O}_{3}\right)$ on foliage and indirect, soil-mediated impacts of $\mathrm{N}$ and $\mathrm{S}$ deposition on roots that may cause nutrient deficiencies and aggravate natural stress, such as deviation with respect to the 1961-1990 reference period for the Northern hemisphere (University of East Anglia data set) averaged using a 10-year moving window. The figure also shows the ICP Level and Level II forest monitoring networks in Europe (big grey bars), that started in 1986 and 1994

physiological drought and the occurrence of pests and diseases (e.g. Landmann and Bonneau 1995). The relative contribution of a given factor may vary on its spatial and temporal distribution, i.e. between regions in Europe and from year to year.

Especially in the eighties and nineties of the previous century, there has been a large research effort to gain insight in the mechanisms behind air-pollution impacts on forest condition by a combination of experiments, monitoring and modelling. Based on this research, the following air-pollution related impacts on forest condition and forest growth have been hypothesized (see e.g. De Vries et al. 2000b):

- Elevated concentrations of the gases $\mathrm{SO}_{2}$ and $\mathrm{O}_{3}$, causing (i) leaf stomata disturbances and premature senescence, leading to water regulation stress and physiological drought, (ii) reduction or shift of carbon allocation leading to a weakened root system 
and (iii) accelerated foliar leaching affecting the nutrient status.

- Eutrophication by elevated $\mathrm{N}\left(\mathrm{NO}_{3}, \mathrm{NH}_{4}\right)$ deposition inputs, causing (i) a shift in deficiency from $\mathrm{N}$ to base cation nutrients $(\mathrm{Bc})$, where $\mathrm{Bc}$ stands for the sum of calcium $(\mathrm{Ca})$, magnesium $(\mathrm{Mg})$ and potassium $(\mathrm{K})$, due to elevated demands induced by an initial growth increase, (ii) enhanced drought stress since an elevated $\mathrm{N}$ input favours growth of canopy biomass, whereas root growth is relatively unaffected and (iii) an increased sensitivity to natural stresses, such as frost and fungal diseases.

- Soil acidification by $\mathrm{S}\left(\mathrm{SO}_{4}\right)$ and $\mathrm{N}$ deposition, including (i) the loss of $\mathrm{Bc}$ from the soil causing deficiency of these nutrients (notably $\mathrm{Mg}$ ), (ii) the release of toxic $\mathrm{Al}$ affecting fine root growth and inhibiting $\mathrm{Bc}$ uptake and (iii) a decrease in $\mathrm{pH}$ that may increase the mobility of heavy metals.

Elevated atmospheric $\mathrm{N}$ deposition can also cause changes in plant species composition and the following main mechanisms for effects are considered (Bobbink et al. 2010):

- Direct toxicity of nitrogen gases and aerosols may result in changes in physiology and reduce growth at high concentrations,

- Increased availability of nitrogen may result in an increase in plant productivity, litter production and $\mathrm{N}$ mineralisation, and thus cause competitive exclusion of characteristic species by fast-growing nitrophilic species,

- High concentrations of ammonium and ammonia in the soil solution may be toxic to sensitive plant species, especially in habitats with moderately acidic conditions

- $\mathrm{N}$ deposition may result in soil acidification causing acid-resistant plant species to become dominant and species typical of intermediate $\mathrm{pH}$ to disappear.

- High availability of nitrogen may increase susceptibility to secondary stress and disturbance factors, such as plant pathogens and insect pests.

At present, the concern is related to the (long-term) resilience of forest ecosystems to cope with the interacting impacts of air pollution and climate change, and the possibility to counteract these impacts by forest management. Below, we discuss effects of $\mathrm{N}$ and acid deposition, $\mathrm{O}_{3}$ exposure, and the impacts of climatic factors.

Aims of the large-scale forest monitoring networks in Europe

As a consequence of the concern of acid deposition effects, a large-scale monitoring of forest condition began under the umbrella of the United Nations Economic Commission for Europe (UN-ECE) and EU resulting in the International Co-operative Programme on Assessment and Monitoring of Air Pollution Effects on Forests (ICP Forests) network in the mid-1980s (Lorenz 1995) and a related EU Scheme on the Protection of Forests against Atmospheric Pollution. ICP-Forests is part of the UN-ECE Long-Range Transboundary Air Pollution (LRTAP) convention. From 1986 onwards, data on tree crown condition, i.e. defoliation and discoloration, were gathered annually at forested plots that were placed in a systematic fashion (in most countries on a $16 \times 16 \mathrm{~km}$ grid), following harmonized methods and centrally stored (e.g. Fischer et al. (2010; e.g. EC-UN/ECE 2007). The major aim of this so-called Level I Monitoring Programme was to gain insight in the geographic and temporal variations in forest condition and its possible relationship with stress factors, including air pollution. As it became more and more clear that large-scale monitoring was not able to answer questions regarding the cause-effect relationships, a "Pan- European Programme for Intensive and Continuous Monitoring of Forest Ecosystems" (the socalled Level II Monitoring Programme) started in 1994 under the umbrella of the UN-ECE/ICP Forests and EU, with currently approximately 760 permanent observation plots, located in 30 participating countries, including 500 plots with data on both atmospheric deposition and forests ecosystem impacts (De Vries et al. 2003c; Lorenz and Becher 2012). In the sequel both networks are referred to as the ICP Forests Level I and Level II networks. An overview of the measurements carried out and the methods used in both monitoring networks is given in Ferretti and Fischer (2013).

The ICP Forest monitoring programmes initially focused on air pollution impacts on forest nutrition and forest health, since the results should be useful for the validation and further development of protocols on air pollution control strategies. However, over time, natural stress factors and climate change gained increasing attention, including impacts on forest growth and plant 
species diversity of the forest ground vegetation. This change in focus follows from the changes in environmental conditions shown in Fig. 1. In 1985, when the time that the first large-scale forest health monitoring began at so-called Level I plots, $\mathrm{S}$ and $\mathrm{N}$ emissions and related acidification effects were top priority in forest impact research. However, since then, $\mathrm{S}$ emissions have declined by $75 \%$ to only $160 \%$ of pre-industrial times, while total $\mathrm{N}$ emissions have only declined by $25 \%$ and are still roughly four times as high as in the 19th century. $\mathrm{CO}_{2}$ rise had slightly increased from between $0.5 \mathrm{ppm}$ per year until 1985 to 1.7 ppm per year between 1980 and 2007. Temperature has risen more dramatically with an increase of almost $0.8{ }^{\circ} \mathrm{C}$ since 1980 (double the value of the previous 100 years). Thus, during the short period of large-scale forest monitoring in Europe, environmental conditions have drastically changed, illustrating the increasing interest in the combined interacting impacts of $\mathrm{N}$ deposition, $\mathrm{NO}_{\mathrm{x}}$ induced $\mathrm{O}_{3}$ exposure and climate change.

Whereas the ICP Forests Level I network predominantly aims to gain insight in the geographic and temporal variations in forest condition, the aim of the ICP Forests Level II network is to clarify cause-effect relationships. The ICP Forests Level II network includes 15 different surveys, with an assessment of crown condition and damages, tree stem increment and the chemical composition of foliage and soil on all plots, whereas atmospheric deposition, meteorological parameters, soil solution chemistry, ground vegetation composition litterfall, $\mathrm{O}_{3}$ injury, ambient air quality, ground vegetation biomass, leaf area index and soil water are conducted on a number of selected permanent observation plots spread over Europe (Ferretti et al. 2013). The Level II network is now following trends in stresses and responses for approximately 760 sites spread over 40 European countries, with 15 -year time series. These data allow an evaluation of the impacts due to changes in weather conditions, including extremes, $\mathrm{O}_{3}$ exposures and deposition of atmospheric $\mathrm{S}$ and $\mathrm{N}$ compounds.

Aim and contents of this paper

In this paper, field evidence is presented of various impacts of air pollution and climate change on forest ecosystems based on monitoring data from the ICP Forests Level I and Level II networks, with a focus on the ICP Forests Intensive Monitoring Level II network. First, a summary is given of impacts of air pollution and climate on forests ecosystems as reported in the literature on the basis of laboratory and field research, including hypotheses on the overall interacting impacts of air pollution and climate change. Next, results from monitoring studies, both at a European wide scale and related national studies, are presented in terms of measured trends and geographic variation in $\mathrm{N}$ and $\mathrm{S}$ deposition and $\mathrm{O}_{3}$ concentrations/exposure, followed by results on effects of elevated $\mathrm{N}$ and $\mathrm{S}$ inputs and/or $\mathrm{O}_{3}$ exposure and/or climate on:

- Nutrient status: element budgets, soil solution chemistry and foliar chemistry

- Forest health in terms of crown condition and crown transparency

- Forest growth and related tree carbon sequestration

- Species diversity of the ground vegetation

We conclude with an evaluation of the monitoring results in view of the knowledge based on results of laboratory and field studies. Rather than giving an indepth review of the interactions between air quality and climate on forest ecosystems, we present a broad overview of empirical, field data based, forest responses to many drivers.

\section{Impacts as derived from laboratory and field studies}

An overview of the potential impacts of air quality and climate on forest ecosystems in terms of the soil and solution quality, nutrition, condition and growth of forests (trees) and the species composition of forest ground vegetation is given in Table 1 . The various impacts are discussed further in view of results of laboratory and field studies reported in literature. Experimental studies under controlled conditions are valuable contributions for the mechanistic understanding of effects of drivers on forests, but it is often difficult to upscale their findings to adult trees, grown under real field conditions. In addition, field studies do give insight at field scale, but results are often influenced with other confounding factors and results are only valid for the site where the investigation took place. However, both sources of information give insight in, and allow hypotheses of, the interacting impacts of air quality and climate on forests ecosystems. 
Table 1 Tentative overview of key stress factors for different effects in various ecosystem compartments. A ' + ' signifies that an impact is expected, whereas a '-“ implies no impact. A '+/-' signifies that the impact is likely to be small (after De Vries et al. 2003d)

\begin{tabular}{|c|c|c|c|c|c|c|c|c|}
\hline \multirow[t]{3}{*}{ Compartment } & \multirow[t]{3}{*}{ Effect } & \multicolumn{7}{|c|}{ Key stress factors } \\
\hline & & \multicolumn{2}{|l|}{ Weather } & \multicolumn{3}{|c|}{ Air pollution } & \multicolumn{2}{|c|}{ Ecological conditions and forest management } \\
\hline & & Drought & Temperature & $\mathrm{N}$ & Acidity & Ozone & Biotic factors & Site \& stand characteristics \\
\hline Soil and soil solution & Quality & + & - & + & + & - & - & + \\
\hline \multirow[t]{3}{*}{ Tree } & Nutrition & + & + & + & + & $+/-$ & - & + \\
\hline & Condition & + & + & + & + & + & + & + \\
\hline & Growth & + & + & + & + & + & $+/-$ & + \\
\hline Ground vegetation & Species composition & + & + & + & + & + & + & + \\
\hline
\end{tabular}

Nitrogen and sulphur deposition impacts

\section{Overall impacts at increasing nitrogen saturation}

Atmospheric deposition has an impact on forest ecosystems through "eutrophication by nitrogen" and soil acidification. Nitrogen is an essential plant nutrient and many terrestrial ecosystems are adapted to conditions of low $\mathrm{N}$ availability, a situation that often leads to plant communities with high species diversity (Bobbink et al. 1998). Aber et al. (1989) launched the theory on ecosystem nitrogen saturation and the different stages that can be identified in view of: (i) impacts on soil chemical processes such as mineralization, immobilization, nitrification, affecting $\mathrm{N}$ leaching, (ii) plant nutrition and forest growth and (iii) plant species diversity. Until a certain physiological optimum is reached, forests will react to additional $\mathrm{N}$ inputs by an increased biomass production. Below the threshold level for growth, however, changes in the ecosystem are already observed. Especially the forest vegetation may gradually change towards more nitrophilic species. Changes in the plant species diversity of the forest undergrowth towards more nitrophilic species have been observed at levels where the growth of forest may still respond to additional N (Ellenberg 1985; Bobbink et al. 1998; Bobbink and Hettelingh 2011). In forested plots with a continuous elevated $\mathrm{N}$ input, the ecosystem may approach " $\mathrm{N}$ saturation" (Aber et al. 1989). In this stage, the leaching of $\mathrm{N}$, mostly as nitrate $\left(\mathrm{NO}_{3}\right)$ will increase. At very high $\mathrm{NH}_{4}$ deposition levels, elevated $\mathrm{NH}_{4}$ accumulation may occur in the topsoil (e.g. Roelofs et al. 1985). Elevated leaching of $\mathrm{NO}_{3}$, in combination with sulphate $\left(\mathrm{SO}_{4}\right)$, is associated with elevated leaching of $\mathrm{Al}$ and/or base cations (BC). This cation release, either by weathering or by exchange of protons against $\mathrm{Al}$ and $\mathrm{BC}$, implies a decrease in the acid neutralizing capacity of the soil, which is defined as soil acidification (Van Breemen et al. 1984). Soil acidification is associated with a decrease in $\mathrm{pH}$ and base cation saturation and an increase of the concentration of $\mathrm{Al}^{3+}$ in the soil solution, (Cronan and Grigal 1995; Marschner 1990; Mengel 1991), which in turn causes a decrease in the ratio of nutrient base cations $(\mathrm{Bc})$, i.e. calcium $(\mathrm{Ca})$, magnesium $(\mathrm{Mg})$ and potassium (K) to $\mathrm{Al}$ (e.g. Sverdrup and Warfvinge 1993; Cronan and Grigal 1995). In this stage, a decrease in forest condition and even forest growth is assumed to occur (Aber et al. 1989, 1998).

\section{Forest condition}

Enhanced dissolution of Al by deposition of acidifying $\mathrm{N}$ and $\mathrm{S}$ compounds has been considered a probable threat to forest vitality (Ulrich 1984; Ulrich et al. 1980). Hypothesized mechanisms of Al toxicity are hampered root growth and inhibition of uptake of nutrient base cations (Bc) (Matzner and Murach 1995; Schulze 1989), which may be aggravated by a loss of mycorrhiza or root damage (e.g. Roelofs et al. 1985) or increased levels of dissolved $\mathrm{NH}_{4}$ (Boxman et al. 1988).

An excess input of $\mathrm{N}$ may furthermore increase the $\mathrm{N}$ content in foliage, which in turn may cause a nutritional imbalance, i.e. causing a shift in deficiency from $\mathrm{N}$ to the macro nutrients $\mathrm{K}, \mathrm{P}, \mathrm{Mg}$ and $\mathrm{Ca}$. The chemical composition of the foliage of forest trees is an important indicator for tree nutrition. It provides information on deficiency or excess of nutrients, either in absolute values or relative to the content of other elements. 
Increased growth rate and elevated $\mathrm{N}$ concentrations in foliage may dilute the pool of other nutrients in absolute or relative terms. Furthermore, strong accumulation of $\mathrm{N}$ in foliage (e.g. as amino acids) may cause an increased sensitivity to climatic factors, such as frost and drought (Aronsson 1980; De Visser 1994) and diseases and plagues, such as attacks by fungi on (Roelofs et al. 1985; Van Dijk et al. 1992; Flückiger and Braun 1998). It may also cause water stress as a result of increased canopy size, increased shoot/root ratio, and loss of mycorrhizal infection. In this context, a critical $\mathrm{N}$ content of $1.8 \%$ in needles has often been mentioned in the literature (Aronsson 1980). Apart from laboratory experiments, the hypothesis of acid deposition induced forest condition decline was based on field observations and foliage analyses, showing e.g. relations between acid deposition, deficiencies of $\mathrm{Mg}$ and $\mathrm{K}$ based on foliar analysis and yellowing of needles (Zöttl and Mies 1983). In the eighties, several authors considered soil acidification, as the main cause for forest decline (for example Ulrich and Pankrath 1983; Hutchinson et al. 1986)

\section{Forest growth}

As summarized by Kozlowski and Pallardy (1996), the requirements for tree growth are carbon dioxide, water and minerals for raw materials, light as energy resource, oxygen, and favourable temperature for growth processes. The capacity for photosynthetic processes (i.e. foliar biomass) and the competition for resources are constraining tree growth. The impact of the deposition of acid $\mathrm{N}$ and $\mathrm{S}$ compounds on forest growth can thus be positive, due to a fertilizing effect of $\mathrm{N}$ deposition, and negative due to a weakening of the forest condition by mechanisms discussed above. Since the productivity of many temperate ecosystems is $\mathrm{N}$ limited, adding $\mathrm{N}$ via deposition has the potential to increase growth, and therefore to sequester $\mathrm{CO}_{2}$ from the atmosphere. A range of studies has shown positive forest growth and $\mathrm{C}$ accumulation responses under low to moderate $\mathrm{N}$ additions (Vitousek and Howarth 1991; Aber et al. 1995; Bergh et al. 1999; Franklin et al. 2003). Observations of increased tree growth of European forests (Spiecker et al. 1996) are thus associated with the effect of increased $\mathrm{N}$ inputs. Results of ${ }^{15} \mathrm{~N}$ experimental studies on the fate of $\mathrm{N}$, combined with $\mathrm{C} / \mathrm{N}$ ratios in forest ecosystem compartments (e.g. Nadelhoffer et al. 1999) and results of long-term (8-30 year) low dose N fertilizer experiments on the $\mathrm{C}$ pool in biomass and soil (e.g. Högberg et al. 2006; Pregitzer et al. 2008; Hyvönen et al. 2008) showed a clear $\mathrm{N}$ fertilization effect varying between approximately $20-40 \mathrm{~kg} \mathrm{C}$ per $\mathrm{kg} \mathrm{N}$. Several meta-analysis of impacts of $\mathrm{N}$ addition experiments on carbon responses, such net primary production (NPP) and net ecosystem $\mathrm{CO} 2$ exchange, indicated similar positive responses (e.g. LeBauer and Treseder 2008; Wamelink et al. 2009; Liu and Greaver 2009).

The nitrogen saturation hypothesis (Aber et al. 1989, 1998) predicts that the final stages of $\mathrm{N}$ saturation lead to tree decline and even death. Some studies indeed report decreased growth in response to high N-loads (e.g. Magill et al. 1997, 2004). Furthermore, Boxman et al. (1998) observed a growth improvement in a highly N-saturated Scots pine (Pinus sylvestris L.) stand in which the $\mathrm{N}$ input to the forest floor was reduced from $\approx 60 \mathrm{~kg} \mathrm{~N}^{-1} \mathrm{yr}^{-1}$ to $<5 \mathrm{~kg} \mathrm{~N} \mathrm{ha}^{-1} \mathrm{yr}^{-1}$ by means of a transparent roof and application of clean, artificial throughfall water. The mechanism for a decline in growth includes the loss of the nutrient base cations $\mathrm{Ca}, \mathrm{Mg}$ and $\mathrm{K}$ from the soil in response to acid deposition, since their (lowered) availability may limit tree growth. Field studies have shown for example that low foliar $\mathrm{Ca}$ concentrations, associated with low soil $\mathrm{Ca}$ concentrations, were related to elevated rates of dark respiration, and lower rates of net photosynthesis (McLaughlin and Wimmer 1999). Roberts et al. (1989) showed that chlorosis of older needles, associated with reduced photosynthesis and carbohydrate translocation, of Norway spruce (Picea abies) and silver fir (Abies $a l b a$ ) in mountainous areas of central Europe resulted directly from foliar $\mathrm{Mg}$ deficiency. These changes can result in lower rates of root growth and wood development. They indicated that foliar Mg deficiency resulted primarily from low rates of $\mathrm{Mg}$ uptake due to the low availability of $\mathrm{Mg}$ in some acidified soils in central Europe.

\section{Species diversity of ground vegetation}

An important aspect of forest biodiversity is the species composition of the ground vegetation (Fischer et al. 2009). In many countries a shift in species composition has been reported, usually from a cryptogam-dominated to a grass-dominated undergrowth, and an increase in species indicative for nitrogen-rich circumstances (Van Dobben et al. 1999). These changes are now mostly ascribed to deposition of nitrogen compounds 
originating from combustion processes and agriculture (e.g. Tyler 1987; Bobbink et al. 1998; Thimonier et al. 1992; Gilliam 2006). In response, many experimental nitrogen addition studies have been carried out to establish empirical 'critical loads' for nitrogen, i.e. the maximum deposition tolerated by a given ecosystem without a change in species composition (e.g. Achermann and Bobbink 2003) and models have been developed to assess critical loads by simulation (Van Dobben et al. 2006; De Vries et al. 2010). Generalisation of the impacts of $\mathrm{N}$ deposition on the plant species diversity of forest ecosystems across Europe is, however, difficult because the effects of air-borne $\mathrm{N}$ deposition depends on (i) the duration and total amount of the inputs, (ii) the form of the $\mathrm{N}$ input, (iii) the intrinsic sensitivity of the present (plant) species and (iv) the abiotic conditions in the ecosystem (Achermann and Bobbink 2003). A way to gain insight into $\mathrm{N}$ deposition impacts is to relate monitoring data of the ground vegetation with environmental factors, including $\mathrm{N}$ deposition, as described further.

\section{Ozone effects}

As a strong oxidant, $\mathrm{O}_{3}$ causes several types of visible symptoms including chlorosis and necrosis. Compounds resulting from oxidation by $\mathrm{O}_{3}$ interfere with the cell's energy production, decrease the photosynthesis, resulting in slower plant growth and they impair water use efficiency and other functions. Plants weakened by $\mathrm{O}_{3}$ may also be more susceptible to pests, disease, and drought. Ambient $\mathrm{O}_{3}$ concentrations in rural and forested areas have been shown to reach concentrations high enough to produce phytotoxic effects in native vegetation (e.g. Bussotti and Ferretti 1998; Sanz and Millán 1998; Skelly et al. 1999; Sanz et al. 2000; Innes et al. 2001; Ashmore 2005; Ferretti et al. 2007a). For example, from 2000 to 2002, a total of 65 species representing 52 genuses were observed to manifest $\mathrm{O}_{3}$ symptoms in Spain, Italy and Switzerland. Symptomatic species were found at $47 \%$ of the common monitoring plots in 2001 and $38 \%$ in 2002 (Ferretti et al. 2007a).

\section{Forest condition}

Several authors have hypothesized that ambient $\mathrm{O}_{3}$ is one of the key factors resulting in spatial and temporal changes of tree crown defoliation, interacting with acid deposition (Reich 1987; Guderian 1985; Sandermann
1996; Takemoto et al. 2001). It is assumed that their combined effects differ significantly from the sum of individual effects due to their complex synergistic or antagonistic interactions (Bytnerowicz et al. 2007). Relatively few studies have, however, investigated $\mathrm{O}_{3}$ effects on crown condition. Datasets describing $\mathrm{O}_{3}$ effects on adult trees from long-term studies are scarce, given the fact that most of the available knowledge about $\mathrm{O}_{3}$ effects on trees has been gained from juvenile trees (e.g. Baumgarten et al. 2000; Bortier et al. 2000; Kolb and Matyssek 2003; Matyssek and Sandermann 2003; Nunn et al. 2005; Schaub et al. 2005; Gerosa et al. 2009; Vapaavuori et al. 2009) or from intensive studies which focused on a better mechanistic understanding of the physiological and bio-chemical processes within the canopy of several trees (e.g. Matyssek et al. 2007a; Wieser et al. 2013).

The complex interactions between environmental conditions as they occur inside the canopy of adult trees and $\mathrm{O}_{3}$ are thus not fully clarified and the relationship between forest tree crown condition (to describe the condition of entire forest ecosystems) and $\mathrm{O}_{3}$ effects are still not well established (Manning 2005; Ollinger et al. 1997; Percy and Ferretti 2004; Paoletti 2006). Response validation under actual forest conditions with adult trees has become feasible upon recent developments of free-air $\mathrm{O}_{3}$ fumigation systems (Musselman and Hale 1997; Karnosky et al. 2007b; Werner and Fabian 2002). Also, due to the expected increase in future ambient $\mathrm{O}_{3}$ concentrations (Fowler et al. 1999; Percy et al. 2003) it is necessary to determine if exposure to ambient $\mathrm{O}_{3}$ levels actually affects crown condition in natural forests (Manning 2005).

Until approximately 2000, most $\mathrm{O}_{3}$ research focused impacts of the external $\mathrm{O}_{3}$ exposure on forest ecosystems, using either an average or peak $\mathrm{O}_{3}$ concentrations or an accumulated dose over a threshold $\mathrm{O}_{3}$ concentration of $40 \mathrm{ppb}$ (AOT40). The AOT40 index was developed within the context of the UN-ECE as a metric to derive a 'critical level', defined as 'the concentration in the atmosphere above which direct adverse effects on receptors such as plants and ecosystems may occur, according to present knowledge' (Ashmore and Fuhrer 2000). The currently set AOT 40 threshold of 5 ppmh to protect forests from ozone (De Santis 1999) is frequently exceeded in many parts of Europe (Karlsson et al. 2004b). From 2000 to 2002, this critical level was exceeded at $77-100 \%$ of the 81 monitored forest sites across France, Italy, Spain and Switzerland (Gerosa 
et al. 2007). However, already for more than a decade, the uncertainties associated with the metric and the currently applied critical level of $5 \mathrm{ppm} \mathrm{h}$ are clearly articulated under the LRTAP Convention and individual countries are encouraged to modify the approach for application to their local conditions (Ashmore and Fuhrer 2000). Today, there is consensus that the socalled Phytotoxic Ozone Dose (i.e. the accumulated stomatal flux of ozone above a flux threshold of $\mathrm{Y}$, $\mathrm{POD}_{\mathrm{Y}}$ ) exposure index provides much stronger relationships with $\mathrm{O}_{3}$ effects compared to external concentration based exposure indices (Emberson et al. 2000; Simpson et al. 2003; Karlsson et al. 2003; Ashmore et al. 2004; Matyssek et al. 2007a; Mills et al. 2010; Grünhage et al. 2012). Karlsson et al. (2007), for example, has demonstrated that the $\mathrm{O}_{3}$ impact on biomass, as well as on visible injury could be better explained by the accumulated stomatal $\mathrm{O}_{3}$ uptake flux as compared to the concentration based AOT40 index, for young trees. For both, young and adult beech (Fagus sylvatica L.) trees, Baumgarten et al. (2000) showed an improved association between injury and cumulative $\mathrm{O}_{3}$ uptake, as compared to the exposure-based approach. Within the UN$\mathrm{ECE}$, the $\mathrm{POD}_{\mathrm{Y}}$ is therefore now suggested for regional ozone risk assessment instead of AOT40 (Mills et al. 2010).

The Phytotoxic Ozone Dose is calculated as the sum over time of the differences between hourly mean values of the stomatal flux of $\mathrm{O}_{3}$ based on the projected leaf area (PLA), $\mathrm{F}_{\text {st }}$ (in nmol m${ }^{-2}$ PLA s ${ }^{-1}$ ) and a stomatal flux threshold of $\mathrm{Y} \mathrm{nmol} \mathrm{m} \mathrm{m}^{-2} \mathrm{~s}^{-1}$, for an appropriate time-window for the periods when Fst exceeds The value of POD $_{Y}$ is formally named AFstY; Accumulated stomatal Flux over thresholds of $\mathrm{Y}$ nmol $\mathrm{m}^{-2} \mathrm{~s}^{-1}$ ). The POD approach takes into account the varying influences of air temperature, water vapour pressure deficit (VPD) of the surrounding leaves, light (irradiance), soil water potential (SWP) or plant available water (PAW), $\mathrm{O}_{3}$ concentration and plant development (phenology) on the stomatal flux of $\mathrm{O}_{3}$. It therefore provides an estimate of the critical amount of $\mathrm{O}_{3}$ entering through the stomata and reaching the sites of action inside the plant and is species-specific. The stomatal flux-based critical level of $\mathrm{O}_{3}, \mathrm{CLe}_{\mathrm{f}}$ mmol m${ }^{-2}$ PLA, is then the cumulative stomatal flux of ozone, $\operatorname{POD}_{\mathrm{Y}}$, above which direct adverse effects may occur according to present knowledge (Mills et al. 2010). Simpson et al. (2007) applied the EMEP chemical transport model to map both indicators of $\mathrm{O}_{3}$ damage across Europe metrics, the AOT40 and the AFstY for two vegetation types, wheat (Triticum spp.) and beech forests. The results show that exceedances of critical levels for either type of indicator are widespread, but that the indicators give very different spatial patterns of hot spots across Europe (Fig. 2).

The decoupling between external $\mathrm{O}_{3}$ exposure and internal $\mathrm{O}_{3}$ flux becomes particular apparent under limited light conditions or drought (Matyssek et al. 2004; Nunn et al. 2006). Schaub et al. (2007) found a divergence between AOT40 and $\mathrm{O}_{3}$ flux indices under conditions where water vapour deficit (VPD) and soil moisture deficit may limit physiological activity, stomatal conductance and hence $\mathrm{O}_{3}$ uptake into the leaves. The advantage of $\mathrm{O}_{3}$ risk assessment by means of PODy can be demonstrated for Fennoscandia, where the potentially most important effect of a future climate change on stomatal $\mathrm{O}_{3}$ uptake would be mediated through the earlier onset of the start of the growing season, therefore leading to a substantial and increasing risk for negative impacts on vegetation in Northern Sweden (Karlsson et al. 2007). Currently, the flux-based $\mathrm{O}_{3}$ uptake approach has been applied for adult trees of beech (Matyssek et al. 2004; Baumgarten et al. 2009; Schaub et al. 2007; Braun et al. 2010; Gerosa et al. 2008), conifer species such as spruce, larch (Larix) and stone pine (Pinus pinea) (Wieser et al. 2013; Wieser et al. 2002; Nunn et al. 2006; Zapletal et al. 2012) and Mediterranean species such as quercus species (Calatayud et al. 2011; Gerosa et al. 2008; Manes et al. 2007).

\section{Forest growth}

Increasing $\mathrm{O}_{3}$ levels have the potential of limiting carbon sink strength of forest ecosystems (IPCC 2007; Pretzsch et al. 2010; Sitch et al. 2007; Wittig et al. 2009), due to reduced net photosynthesis, accelerated leaf senescence and increased dark respiration (Matyssek et al. 2010b).

The negative impacts of $\mathrm{O}_{3}$ on physiological functions and biomass production have been investigated in a number of experiments. Most has focused on physiological or biochemical effects of $\mathrm{O}_{3}$ exposure, in attempts to determine mechanisms of toxicity, dose response work for risk assessment, or development of diagnostic tests for $\mathrm{O}_{3}$ injury. Many of these demonstrated relationships between $\mathrm{O}_{3}$ exposure and reductions in both growth and leaf gas exchange (Matyssek 


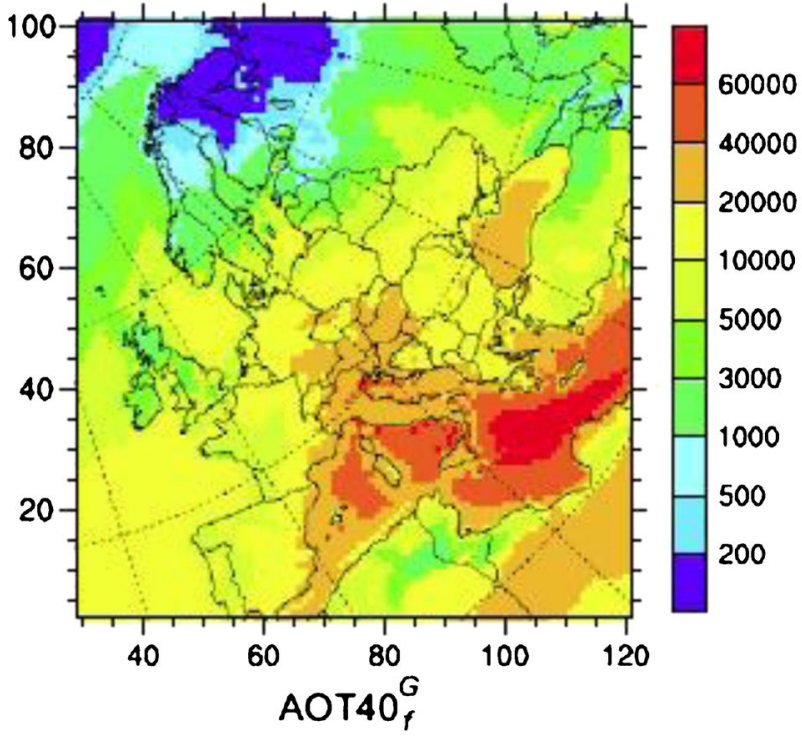

Fig. 2 Calculated geographic variation over Europe of the ozone exposure index AOT40f [ppb h], calculated as the accumulated exposure over a threshold of $40 \mathrm{ppb}$, (left), and the ozone exposure

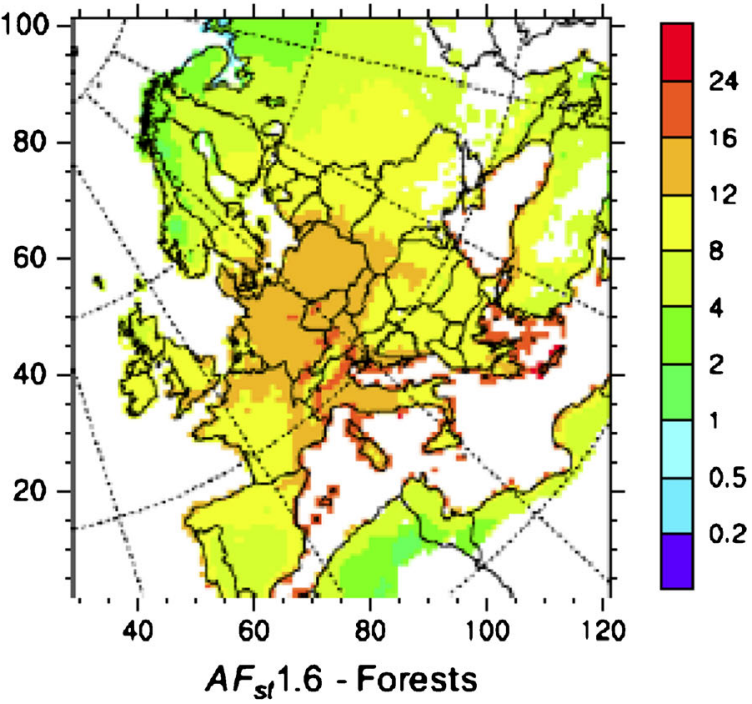

index AFstY $\left[\mathrm{mmol} \mathrm{m}^{-2}\right]$, calculated as the stomatal flux Fst over a threshold Y of $1.6 \mathrm{nmol} \mathrm{m}^{-2} \mathrm{~s}^{-1}$ (right). Source: Simpson et al. 2007

shows a clear decline in growth in response to elevated $\mathrm{O}_{3}$ exposures. With a meta-analysis, including 313 articles covering the period 1970 through 2006, Wittig et al. (2009) addressed the question as how current ambient $\mathrm{O}_{3}$ concentrations decrease productivity relative to preindustrial $\mathrm{O}_{3}$ concentrations. They found that current ambient $\mathrm{O}_{3}$ concentrations of $40 \mathrm{ppb}$ on average significantly reduced total biomass (and therefore carbon storage) of young trees by $7 \%$ compared to trees grown under preindustrial $\mathrm{O}_{3}$ levels. Elevated $\mathrm{O}_{3}$ concentrations of $64 \mathrm{ppb}$ reduced total biomass by $11 \%$ relative to trees grown under ambient $\mathrm{O}_{3}$ concentrations.

While results of experimental studies under controlled conditions, as described above, are valuable contributions for the mechanistic understanding of $\mathrm{O}_{3}$ effects on forest trees, it is difficult to upscale their findings to adult trees, grown under real field conditions (Kolb et al. 1997; Baumgarten et al. 2000; Schaub et al. 2005). For example Nunn et al. (2005) applied a correlative $\mathrm{O}_{3}$ uptake model (Emberson et al. 2000) to relate $\mathrm{O}_{3}$ flux to radial growth and showed that despite similar $\mathrm{O}_{3}$ regimes, young beech seedling grown in phytotrons were more sensitive to $\mathrm{O}_{3}$ relative to adult beech trees due to higher $\mathrm{O}_{3}$ uptake. On the other hand, Kitao et al. (2012) found that $\mathrm{O}_{3}$-induced changes in leaf-level photosynthetic parameters had the capacity of limiting the seasonal photosynthetic carbon gain in the same adult 
beech trees, but the reduction in leaf photosynthesis could not immediately be related to the extent of growth reduction in stems.

Much has been written about the presumed or probable effects of $\mathrm{O}_{3}$ on growth of trees in the forest (Manning 2005). In Europe, estimates of average forest yield losses around $10 \%$ were suggested (Broadmeadow 1998), while values as high as $42 \%$ were suggested for beech (Pretzsch et al. 2010). At the same time, in the eastern USA, growth losses of $0-10 \%$ were predicted (Chappelka and Samuelson 1998). Growth reductions in eastern hardwood trees, ranging from 4 to $12 \%$, were predicted for north-eastern forests (Ollinger et al. 1997). Verifying these loss predictions is difficult, as the bases for most of them are laboratory experiments that may not be relevant for actual field conditions. In fact, much of the available information about $\mathrm{O}_{3}$ effects on trees does not apply well to actual forest conditions and large trees (Matyssek and Sandermann 2003). Due to the complex interrelationships among the parameters affecting tree growth over the life span of a tree, establishing a cause and effect relationship for ambient $\mathrm{O}_{3}$ exposure and tree growth in forests has proven to be a difficult task. Manning (2005) suggests, that smaller, better-defined studies in the forest should lead to a better understanding of factor interaction with $\mathrm{O}_{3}$ in affecting tree growth. While it is difficult to work in natural ambient conditions, studies under these conditions are essential to develop a better understanding of how $\mathrm{O}_{3}$ and environmental factors interact to affect radial growth in trees. In this context, Matyssek et al. (2010b) promotes free-air fumigation studies, which allow whole-plant assessment of adult trees to gain a better understanding of the modifying impact of biotic agents in the presence of natural mycorrhization.

\section{Species diversity of ground vegetation}

Novak et al. (2008) demonstrated that plant competition is an important factor affecting plant responses to $\mathrm{O}_{3}$ stress, but the direction and severity of these effects depend on the interacting species and micro site conditions. Therefore, competition in combination with elevated $\mathrm{O}_{3}$ exposures may alter species composition and diversity over the long run, but quantitative information on this potential impact is yet lacking.
Climate impacts

\section{Crown condition}

Crown transparency, a measure of reduced foliage mass has been shown to be highly influenced by summer drought (Dobbertin and Rigling 2006; Seidling 2007; Carnicer et al. 2011). Drought may affect crown condition and mortality in many ways, i.e. by increasing needle or leaf loss during or after the drought (Christiansen 1992; Gruber 1990; Bussotti et al. 2005; Heiniger and Schmid 1986, 1989; Livsey and Barklund 1993), dying of buds and branches (Aronsson et al. 1978), root mortality and predisposition to attack by Armillaria spp. or other root pathogens (Whitney and Timmer 1983) and reduced foliar nutrient contents (Wehrmann 1961). Experimentally introduced drought stress to stands of spruce and pine have shown a considerable defoliation, measured as a reduction in foliage mass (Christiansen and Nilsen 1990), and yellowing caused by reduced foliar nutrient concentrations (Dambrine et al. 1993). In addition, a dry or hot summer reduces growth (Spiecker 1986), increases attacks by bark beetles and other insects (Worrell 1983), and induces heavy flowering (Owens and Blake 1985), partly at the expense of vegetative shoot formation (Lüscher 1989).

Spring or early summer drought have the potential to reduce current year leaf or needle size (Dobbertin et al. 2010). Extreme drought may either lead to premature leaf or needle shedding causing high crown transparency during the summer, or for conifers it may cause needle loss during autumn which will up show as reduced foliage mass in the following year (Solberg 2004). Most commonly for temperate trees with only one annual flush, however, is that late summer drought causes a decrease in primordial, which subsequently results in reduced foliage mass and shorter shoots in the following season. Water stress is therefore very important with respect to the monitored forest condition. Innes (1993) mentioned that the most alarming and frequent observations of a decrease in forest condition in Central Europe coincided with the dry years 1982 and 1983. Landmann (1995) mentioned that defoliation appears to be highest in soils poorly supplied with water and/or in stands in which trees, at some stage of development, have suffered from competition for water.

Mortality of forest and woodland plants has also been increasingly observed as a response to extreme drought 
and heat events (Allen and Breshears 1998; Allen et al. 2010; Hanson and Weltzin 2000; Breshears et al. 2005; Shaw et al. 2005; Berg et al. 2006; Gitlin et al. 2006; Carnicer et al. 2011). Drought and heat events, such as in 2003 in Europe, reduced net primary productivity (Ciais et al. 2005; Bréda et al. 2006) and increased mortality (Martínez-Vilalta and Piñol 2002; Lloret et al. 2005; Bigler et al. 2006; Dobbertin and Rigling 2006). A widespread increase in tree mortality in the Western United States has also recently been observed and attributed mainly to warming and consequent increases in water stress (Van Mantgem et al. 2009).

\section{Forest growth}

Change in water supply can severely alter above- and below-ground tree growth, as well as affect the vitality of trees (Dobbertin 2005; Waring 1987). Increasing temperature under equal or reduced precipitation will increase the evaporative pressure on plants (Rebetez and Dobbertin 2004). Plants react to drought stress with stomata closure to reduce water loss or leaf wilting (Zweifel et al. 2007). While the reduction of stomatal conductance is an adaptation to drought stress, closed stomata reduces the uptake of atmospheric carbon dioxide, and in turn limits the carbon dioxide fertilization of photosynthesis and therefore reduces carbon uptake (Körner 2003). Reduced photosynthesis may not only result in reduced tree growth and related carbon allocation (Zweifel et al. 2006; Adams et al. 2009; McDowell et al. 2008; Zweifel et al. 2009), but it may also reduce the resistance of trees against insects and pathogens (Kolb et al. 1998). As different species are differently adapted to drought, the inter-tree competition will also be altered.

It is well known that reduced water availability results in decreased tree growth and reduced foliage mass, either by premature leaf shedding or reduced foliage production in the following year (Pallardy 2008). The extreme drought of 2003, for example, led to a reduction of forest growth in low-land forests in central Europe of up to $60 \%$ (Dobbertin 2005; Jolly et al. 2005; Leuzinger et al. 2005). Although respiration loss was also reduced, many forests released more carbon in 2003 than they sequestrated via tree stem growth (Ciais et al. 2005) resulting in a net loss of carbon. Many tree-ring studies have successfully linked ring width reduction to reduced precipitation or increased temperature of various months during or before the current the tree growing season (Schweingruber 1996).

\section{Impacts as derived from monitoring studies}

Geographic variation and trends in acidic atmospheric deposition and ozone exposure at ICP Forests Level II plots

\section{Atmospheric deposition of nitrogen and sulphur}

In the framework of the activities carried out on the ICP Forests Level II plots, atmospheric deposition is measured on the basis of a combination of (i) bulk deposition in the open field in the vicinity (within 1 kilometre) of the Intensive Monitoring plot and (ii) throughfall below the forest canopy within the plot. For monitoring of throughfall data, use was mostly made of funnels whereas gutters were used at a minority of the plots. The sampling frequencies for bulk deposition, throughfall and stemflow measurements were mostly weekly or fortnightly and the number of bulk deposition and throughfall samplers used mostly ranged from $2-6$ and $10-15$, respectively (De Vries et al. 2003c).

The geographic variation in acidic components over Europe is illustrated by maps of the average annual S and N deposition in the period 2005-2007, as presented in Fig. 3. The results show that high $\mathrm{S}$ deposition, and to a lesser extent $\mathrm{NO}_{3}-\mathrm{N}$ deposition, mainly occur in central Europe (Poland, Germany, Czech Republic, Slovak Republic, Slovenia and Romania). High nitrate $\left(\mathrm{N}-\mathrm{NO}_{3}\right)$ and ammonium $(\mathrm{N}-$ $\mathrm{NH}_{4}$ ) deposition also occurs in the Netherlands, Belgium, parts of France, and north of Italy and Spain. The lowest nitrogen deposition was observed on plots in Scandinavia with values mostly below $2 \mathrm{~kg} \mathrm{~N} \mathrm{ha}{ }^{-1} \mathrm{yr}^{-1}$ for both $\mathrm{N}-\mathrm{NO}_{3}$ and $\mathrm{N}-\mathrm{NH}_{4}$.

Trends in $\mathrm{S}$ and $\mathrm{N}$ deposition at Intensive Monitoring plots, assessed over the last 10-15 years, show a clear decline for $\mathrm{S}$ and a less significant decline for $\mathrm{N}$. This follows from recent studies by, Fischer et al. (2010) and Lorenz and Becher (2012), who presented results of trends in S and N deposition between 1998-2007 and 2001-2010, respectively, based on 87 plots with throughfall measurements and 55 plots with bulk deposition measurements. Their results showed an overall 


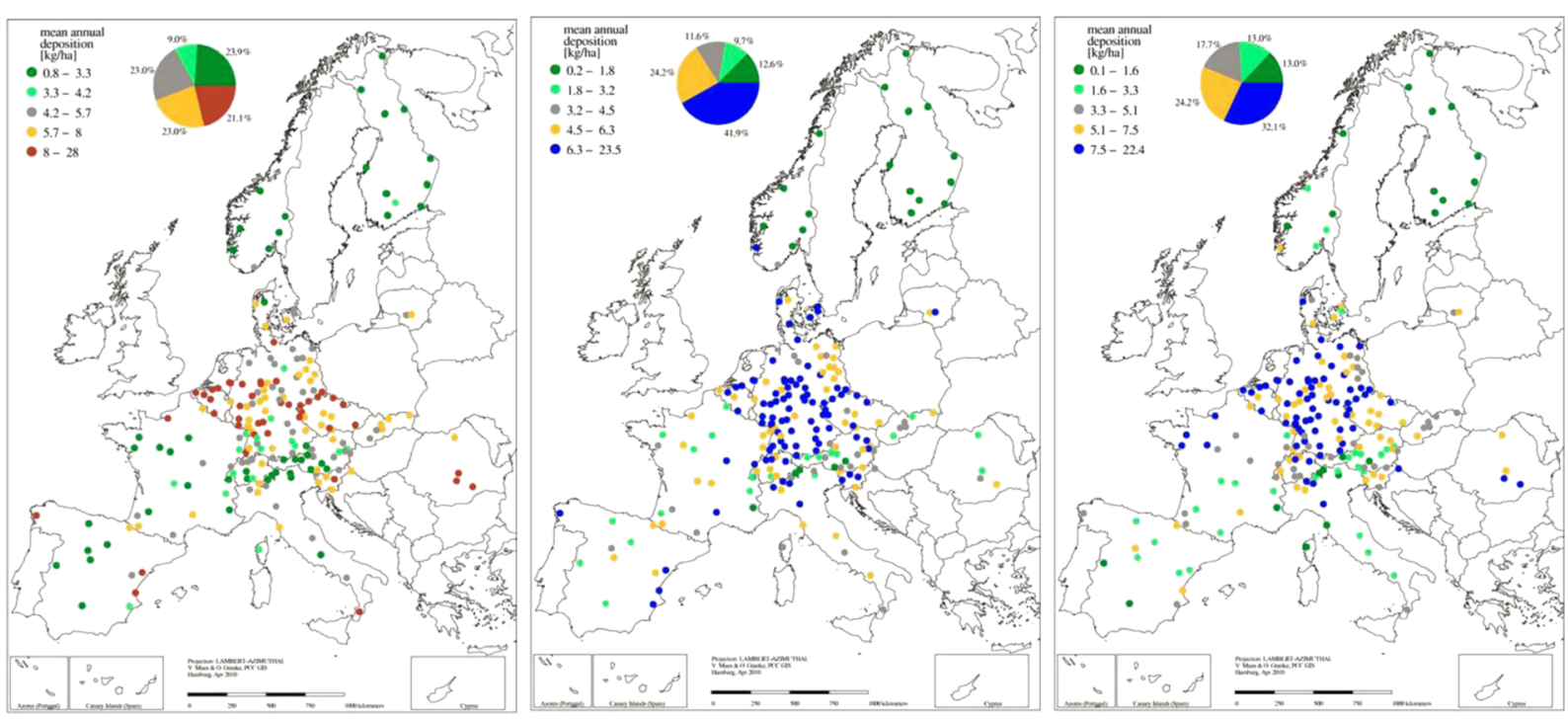

Fig. 3 Mean annual average sulphur $\left(\mathrm{SO}_{4}-\mathrm{S}\right.$; left), nitrate-nitrogen $\left(\mathrm{NO}_{3}-\mathrm{N}\right.$; middle) and ammonium-nitrogen in $\left(\mathrm{NH}_{4}-\mathrm{N}\right.$; right $)$ throughfall deposition in 2005 to 2007. Source: Fischer et al. (2010)

strong decrease of annual S deposition both in bulk deposition and throughfall. For example, mean $\mathrm{S}$ throughfall deposition decreased from $10 \mathrm{~kg} \mathrm{~S} h a^{-1} \mathrm{yr}^{-1}$ in 1998 to $5 \mathrm{~kg} \mathrm{~S} \mathrm{ha}^{-1} \mathrm{yr}^{-1}$ in 2010, implying an average

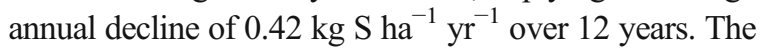
mean $\mathrm{S}$ bulk deposition decreased from about $7 \mathrm{~kg} \mathrm{~S} \mathrm{ha}^{-1} \mathrm{yr}^{-1}$ in 1998 to $4 \mathrm{~kg} \mathrm{~S}^{-1} \mathrm{yr}^{-1}$ in 2010 , implying an average annual decline of $0.25 \mathrm{~kg} \mathrm{~S} \mathrm{ha}^{-1} \mathrm{yr}^{-1}$. The mean throughfall deposition of inorganic $\mathrm{N}$ on plots with continuous measurements from 1998 to 2010 decreased from approximately 11 to $9 \mathrm{~kg} \mathrm{~N}$ ha ${ }^{-1} \mathrm{yr}^{-1}$, i.e. circa $0.16 \mathrm{~kg} \mathrm{~N}^{-1} \mathrm{yr}^{-1}$. Trends were clearer for $\mathrm{NO}_{3}$ than for $\mathrm{NH}_{4}$. At $83 \%$ of the intensive monitoring plots, no significant decrease in atmospheric throughfall deposition was detected (Fischer et al. 2010), illustrating the limited reduction in ammonia $\left(\mathrm{NH}_{3}\right)$ emissions since 1998 .

Maps of trends in $\mathrm{S}$ and $\mathrm{N}$ deposition for the period 1998-2007 (Fig. 4) show that decreases in S deposition, and to a lesser extent $\mathrm{NO}_{3}-\mathrm{N}$ deposition, mainly occur in central Europe, although there is no consistent pattern in the results due to many local factors affecting the deposition. The deposition of $\mathrm{NH}_{4}-\mathrm{N}$, being mainly due to agricultural activities, mostly decrease in high deposition areas with intensive agriculture in the Netherlands, Belgium and Germany in response to emission reduction measures taken in those countries.

\section{Tropospheric ozone concentrations}

In National Air Quality Networks, $\mathrm{O}_{3}$ concentrations are measured with continuous monitors that are costly and mostly concentrated in urban or suburban areas, making it very difficult to infer the $\mathrm{O}_{3}$ spatial patterns, especially in complex mountainous areas or along the sea shore (Bacci et al. 1990; Millán et al. 2000). Passive samplers are considered an alternative, or a complement to continuous monitors, e.g. when a higher density in the measuring network is required. Their use in assessing the ecological effects of tropospheric $\mathrm{O}_{3}$ has significantly increased in recent years (e.g. Manning et al. 1996; Blum et al. 1997; Krupa and Legge 2000; Sanz et al. 2001). In the framework of the activities carried out on the ICP Forests Level II plots, mainly $\mathrm{O}_{3}$ passive sampler measurements were thus carried out since 2000 to (i) gain knowledge into the spatial and temporal exposure trends of $\mathrm{O}_{3}$ concentrations and (ii) to evaluate the potential risk to forest ecosystems (Sanz and Krause 2001).

Biweekly $\mathrm{O}_{3}$ measurements at the ICP Forests Level II network in 2002 showed concentrations ranging between 30 and $45 \mathrm{ppb}$ at most of the stations. Patterns in Germany and France show increasing concentrations going from North to South and towards high-elevation areas, with the seasonal average concentrations rarely 


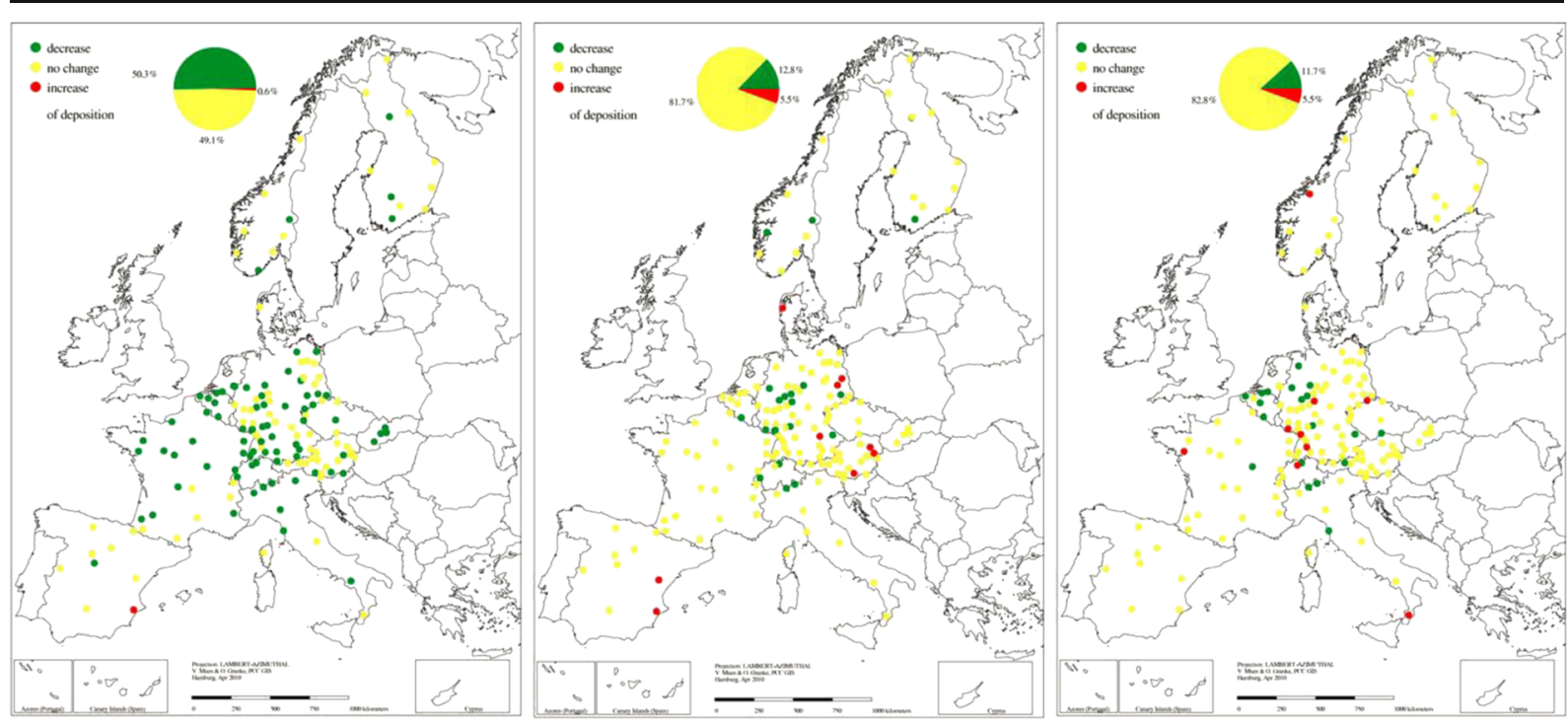

Fig. 4 Trends in sulphate-sulphur $\left(\mathrm{SO}_{4}-\mathrm{S}\right.$; left), nitrate-nitrogen $\left(\mathrm{NO}_{3}-\mathrm{N}\right.$; middle) and ammonium-nitrogen in $\left(\mathrm{NH}_{4}-\mathrm{N}\right.$; right $)$ throughfall deposition from 1998 to 2007. Source: Fischer et al. (2010)

exceeding $45 \mathrm{ppb}$, but there was no distinct geographical pattern in the UK. In Switzerland and Italy, about $30 \%$ of the plots ranged between 45 and $60 \mathrm{ppb}$ in 2002 (Lorenz et al. 2005). Passive sampler measurements for the period 2000-2004 show that the highest $\mathrm{O}_{3}$ concentrations in forest areas across Europe occur in the south (Fig. 5), in particular Italy, Switzerland and Spain (Sanz et al. 2007). Highest measured values occurred in central and northern Italy and in southern Switzerland. These results are consistent with the output from continuous monitors (De Leeuw and Bogman 2001; Fiala et al. 2002, 2003). The hot-spots in Italy and Switzerland are under the influence of the industry and traffic emissions originating from the Po Valley, including the city of Milan (e.g. Novak et al. 2003; Staffelbach et al. 1997b; Staffelbach et al. 1997a). Spring and summer $\mathrm{O}_{3}$ concentrations are high enough to be of potential risk to sensitive plants in nearly all regions of Europe. The currently recognized AOT40 thresholds for damage to forest trees are frequently exceeded in many areas of Europe.

The annual changes in $\mathrm{O}_{3}$ concentrations in the 2000-2004 period observed at the monitoring plots (Fig. 6) were mainly related to different climatic conditions (Sanz et al. 2007), since $\mathrm{O}_{3}$ concentrations increase with higher air temperature and solar radiation and decrease in cloudy and rainy periods (e.g. Amoriello et al. 2003). Warm and sunny weather enhances the $\mathrm{O}_{3}$ concentration because of the emission of volatile hydrocarbons (including vegetation emissions) increases with temperature, higher solar radiation increases photochemical processes, and high temperature results in more rapid chemical $\mathrm{O}_{3}$ formation (Fiala et al. 2003). Over the 2000-2004 period, highest concentrations were measured in 2003, a year with one of the hottest summers on record for Europe, producing the highest $\mathrm{O}_{3}$ values for Central Europe since the 80s. The high air temperatures measured during the summer of 2001 are also reflected in the higher $\mathrm{O}_{3}$ levels during that year. In the five-year study period, concentrations were lowest in 2004, due to the relatively low solar radiation recorded during April-September 2004 (Fig. 6).

Water and element budgets and nutrient-acidity status

\section{Water budgets}

Water influences the availability of nutrients by affecting bio/geochemical processes and the loss of nutrients from the rooting zone by leaching. To understand the element cycles in a forest ecosystem, a quantification of the hydrological situation is indispensable. The hydrological budget is mainly determined by the input of water by rainfall and the loss of water from the forest by interception evaporation, soil evaporation, transpiration and leaching. The first and only water flux study at a European wide scale has been carried out by Van der 
Fig. 5 Mean ozone

concentrations for April-

September in 2000-2004 at 91

Intensive Monitoring plots. Due

to the higher solar radiation,

concentrations typically increase

from North to South Europe.

Source: EC-UN/ECE 2007

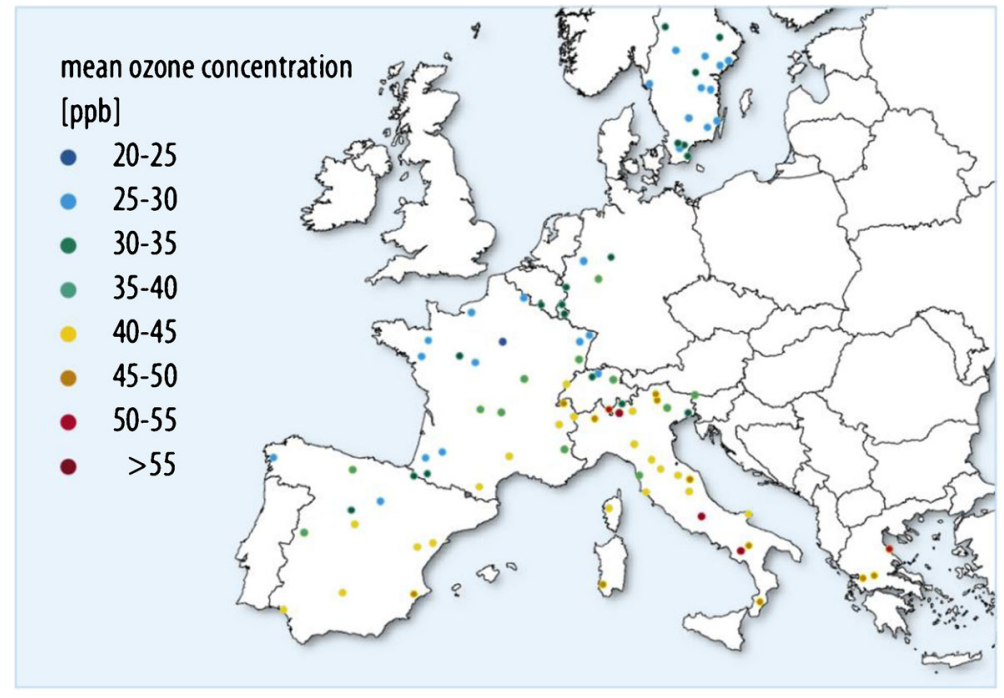

Salm et al. (2007b), using data from hundreds of intensive forest monitoring plots for the period 1996-1998. They calculated interception evaporation on the basis of measured bulk deposition and throughfall, while soil evaporation, transpiration and leaching were calculated with a hydrological simulation model called SWATRE. Van der Salm et al. (2007b) concluded that yearly but also monthly and two weekly measured throughfall data were quite well simulated for 245 plots passing a calibration procedure and various quality checks.

Evapotranspiration and leaching fluxes varied considerably for the investigated plots (Fig. 7). Transpiration fluxes are generally highest $(>450 \mathrm{~mm})$ in central Europe where both rainfall and radiation are relatively high (Fig. 7 left). At most plots in southern Europe, transpiration is somewhat lower due to the limited rainfall, except for plots in mountainous areas. In northern Europe transpiration fluxes are lower than in central Europe due to the decrease in radiation with increasing latitude and the relatively low precipitation in part of Sweden and Finland. The leaching fluxes (Fig. 7 right) closely resemble the precipitation and throughfall maps. High leaching fluxes are found in North-western Scandinavia, Britain and Ireland and on some plots in mountainous areas in central and southern Europe.
Fig. 6 Shares of plots belonging to 8 classes of ozone concentrations based on the mean ozone values (April-September) for the period 2000-2004. Only plots with at least $70 \%$ data cover during the observation period were considered. Source: (ECUN/ECE 2007)

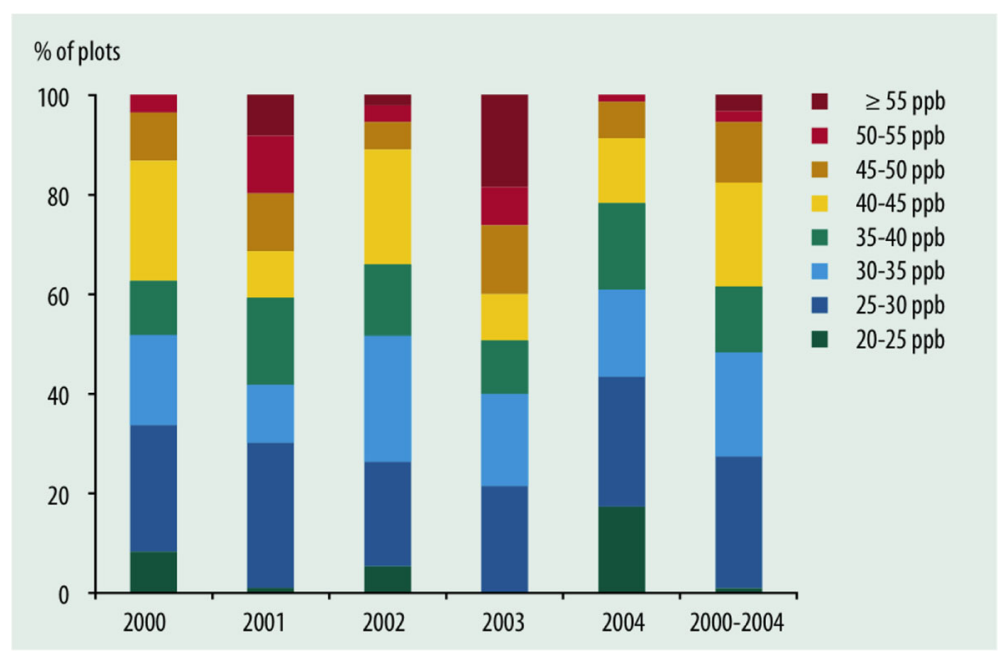



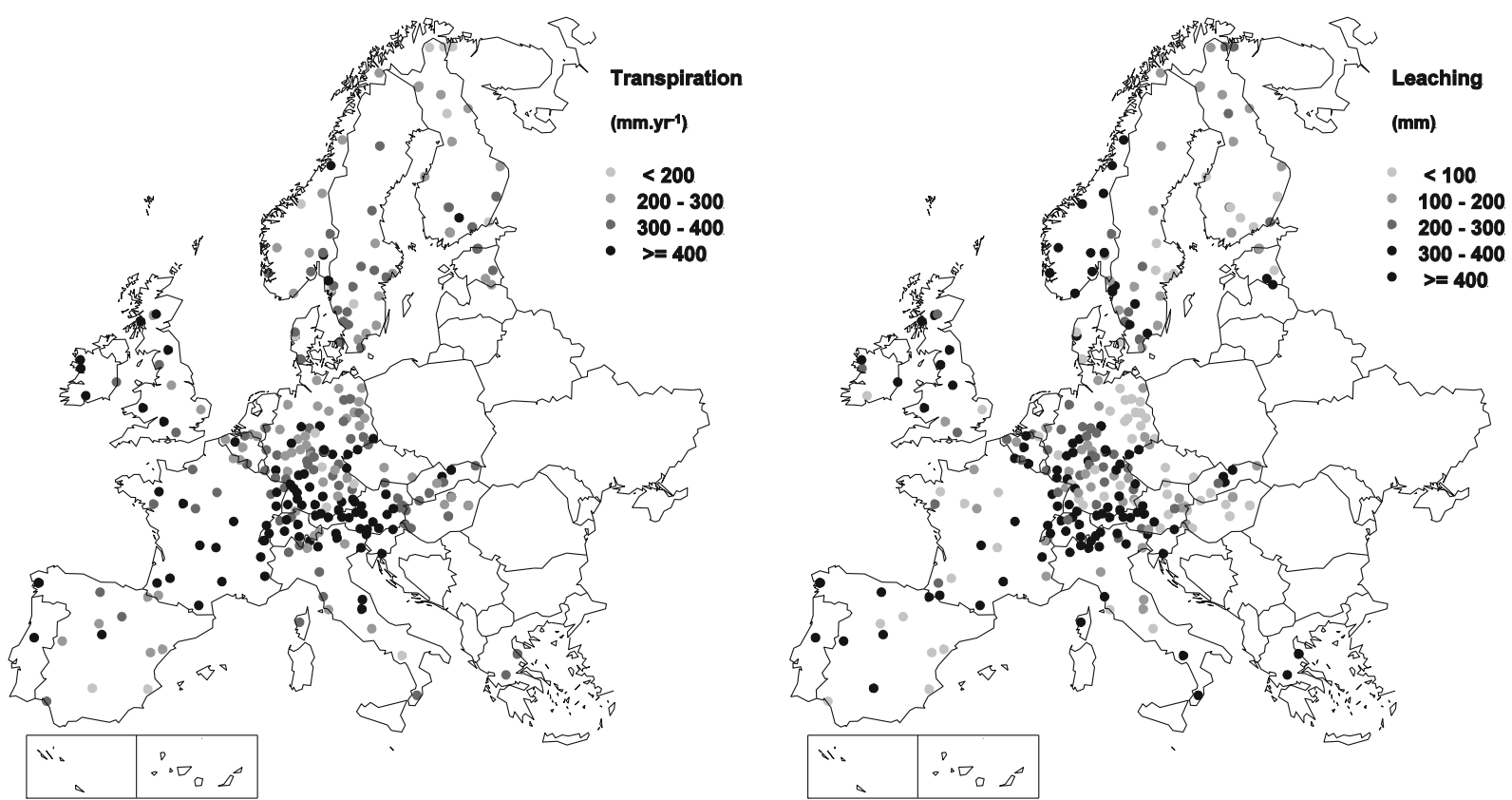

Fig. 7 Average annual transpiration fluxes (left) and average leaching fluxes (right) for 245 European forest monitoring plots for the period 1996-1998. Source: Van der Salm et al. (2007b)

\section{Element budgets}

At 121 intensive forest monitoring plots, the inputs and outputs of $\mathrm{S}$ and $\mathrm{N}$ compounds (total $\mathrm{N}, \mathrm{NH}_{4}$ and $\mathrm{NO}_{3}$ ), $\mathrm{Al}$ and $\mathrm{BC}(\mathrm{Ca}, \mathrm{Mg}, \mathrm{K}$ and $\mathrm{Na})$ have been assessed for the same period 1996-1998, as presented in De Vries et al. (2007). Total $\mathrm{N}$ and $\mathrm{S}$ deposition was derived from both bulk deposition and throughfall while accounting for forest canopy exchange, while $\mathrm{N}$ and $\mathrm{S}$ leaching was based on a combination of measured dissolved element concentrations and the water balance model SWAP, using methods described in detail in De Vries et al. (2007). Results showed that on average $\mathrm{SO}_{4}$ behaves as a tracer, since average $\mathrm{SO}_{4}$ leaching fluxes are comparable to $\mathrm{SO}_{4}$ deposition, whereas $\mathrm{N}$ is strongly retained in the soil and/or denitrified since $\mathrm{N}$ leaching is generally much lower than $\mathrm{N}$ deposition (Fig. 8a, b). The higher leaching of $\mathrm{SO}_{4}$ implies that $\mathrm{S}$ deposition is still the dominant source of actual soil acidification, despite the fact that $\mathrm{N}$ deposition is higher on average.

Although average $\mathrm{S}$ leaching is close to $\mathrm{S}$ deposition, there is a large variation in both fluxes that can partly be attributed to errors in both the input and output assessment (Fig. 8a). At several sites the leaching of $\mathrm{SO}_{4}$ is considerably higher than the deposition indicating a strong release of $\mathrm{SO}_{4}$, which has been adsorbed during previous decades. Results of the leaching of total $\mathrm{N}$ and $\mathrm{NO}_{3}$ against the total $\mathrm{N}$ deposition showed that the leaching of $\mathrm{N}$ is generally negligible below a total $\mathrm{N}$ input of $10 \mathrm{~kg} \mathrm{ha}^{-1} \mathrm{yr}^{-1}$ (Fig. 8b). These results are in accordance with those found by e.g. Gundersen et al. (1998), Dise et al. (1998a, b, 2009), MacDonald et al. (2002) and Van der Salm et al. (2007a), who found those results, largely based on a review of literature data while using $\mathrm{NO}_{3}$ leaching and throughfall $\mathrm{N}$ inputs. At $\mathrm{N}$ inputs between 10 and $20 \mathrm{~kg} \mathrm{ha}^{-1} \mathrm{yr}^{-1}$, leaching of $\mathrm{N}$ is generally elevated, although lower than the input indicating $\mathrm{N}$ retention at the plots. At $\mathrm{N}$ inputs above $20 \mathrm{~kg} \mathrm{ha}^{-1} \mathrm{yr}^{-1}$, $\mathrm{N}$ leaching is also mostly elevated and in several cases (seven plots), it is near or even above (for two plots) the $\mathrm{N}$ deposition (Fig. 8b). The latter situation indicates a clear disturbance in the $\mathrm{N}$ cycle in response to the elevated $\mathrm{N}$ input. $\mathrm{NO}_{3}$ dominates $\mathrm{N}$ leaching and the increase in $\mathrm{N}$ leaching in response to elevated $\mathrm{N}$ loads (above $20 \mathrm{~kg} \mathrm{ha}^{-1} \mathrm{yr}^{-1}$ ) appears to be larger for deciduous trees than for conifers (De Vries et al. 2007).

In acidic soils, atmospheric deposition of $\mathrm{S}$ and $\mathrm{N}$ compounds do lead to elevated $\mathrm{Al}$ concentrations, in response to elevated concentrations of $\mathrm{SO}_{4}$ and $\mathrm{NO}_{3}$. The range in $\mathrm{Al}$ leaching fluxes at the same 121 Intensive Monitoring plots is quite comparable to the 

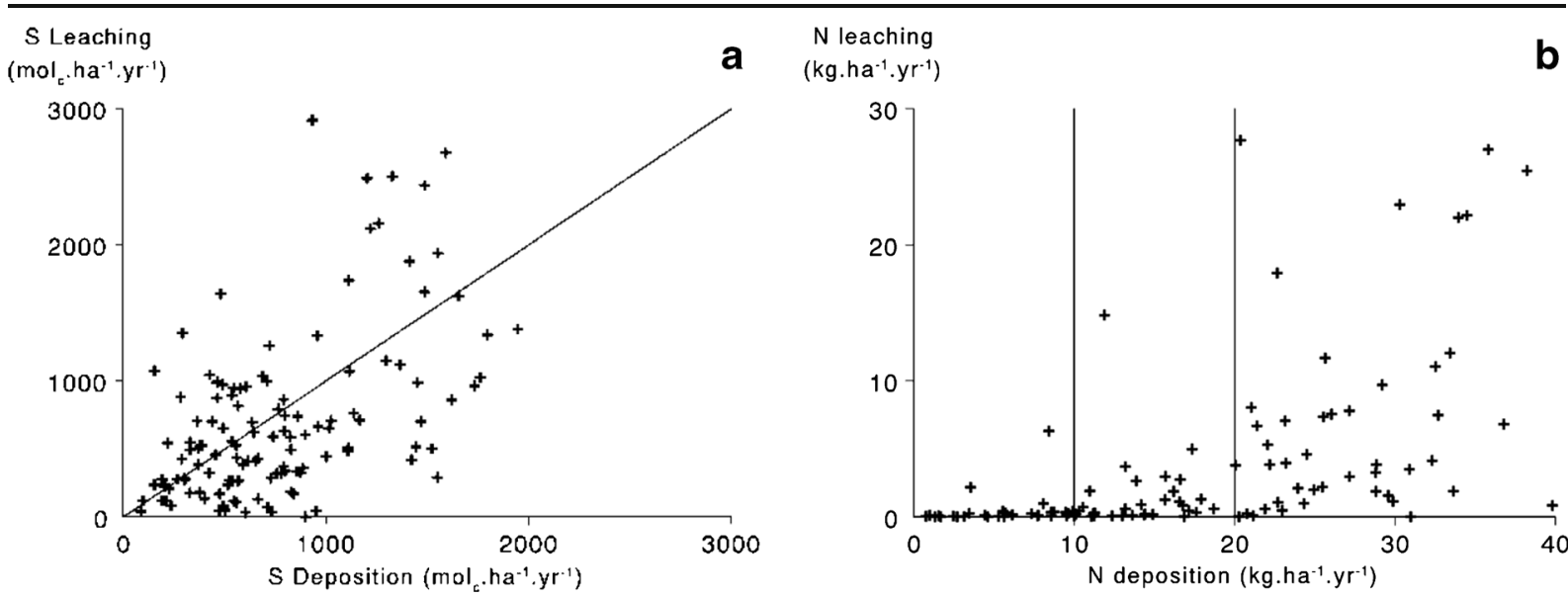

Fig. 8 Relations between total deposition and leaching fluxes of S (a) and N (b) at 121 forest monitoring sites for the period $1996-1998$. Source: De Vries et al. (2007)

range in $\mathrm{S}$ and $\mathrm{N}$ deposition (Fig. 9a). At several sites, $\mathrm{Al}$ leaching fluxes are even higher than the acid deposition. This occurred at sites where the leaching of $\mathrm{SO}_{4}$ is higher than the input ( $\mathrm{S}$ release from the soil causing acidification) and acid input is almost completely buffered by the release of Al. Sites where the Al leaching flux is lower imply that part of the potential acid input is buffered by $\mathrm{S}$ and/or $\mathrm{N}$ retention and/or BC release. In soils with a $\mathrm{pH}$ above 5.0, the release of $\mathrm{Al}$ is generally negligible, independent of the $\mathrm{S}$ and $\mathrm{N}$ input, since $\mathrm{BC}$ release by weathering and cation exchange buffers the incoming net acidity in those soils, but at sites below $\mathrm{pH} 4.5$ there is high correlation between $\mathrm{Al}$ concentration and the sum of $\mathrm{SO}_{4}$ and $\mathrm{NO}_{3}$ concentration

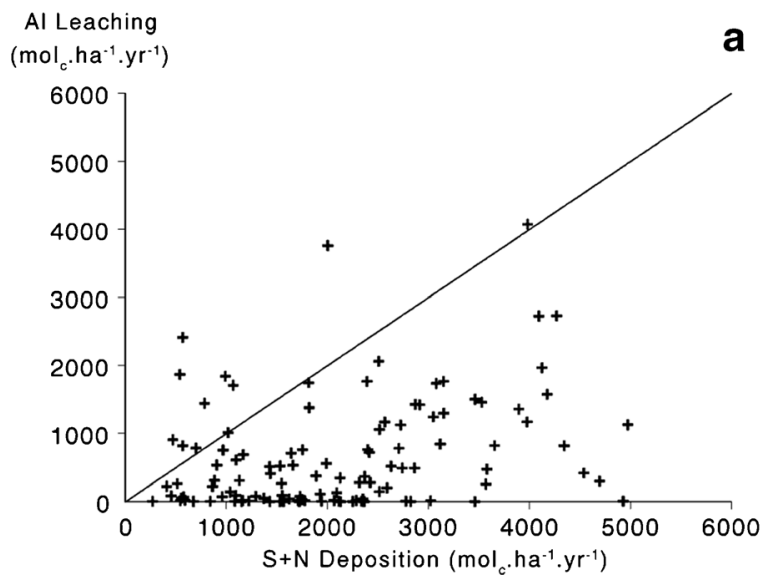

Fig. 9 Relations between $\mathrm{Al}$ leaching fluxes and the total deposition flux of $\mathrm{S}+\mathrm{N}$ (a) and the concentration of total $\mathrm{Al}$ against total $\mathrm{SO}_{4}+\mathrm{NO}_{3}$ in the subsoil of Intensive Monitoring plots with a $\mathrm{pH}<4.5$ at 121 forest monitoring sites (b).
(Fig. 9b). Comparable results were found by Dise et al. (2001).

\section{Soil solution and foliar chemistry}

Soil chemistry data at a single point in time do not give adequate information on the impacts of acid atmospheric deposition data due to natural soil acidification that may also lead to low $\mathrm{pH}$ values and low base saturation under natural circumstances. De Vos and Cools (2011) summarize the results of a second European Forest Soil Condition survey in which they evaluate carbon and nutrient stocks, acidification and contamination levels, as compared to the first European forest soil condition

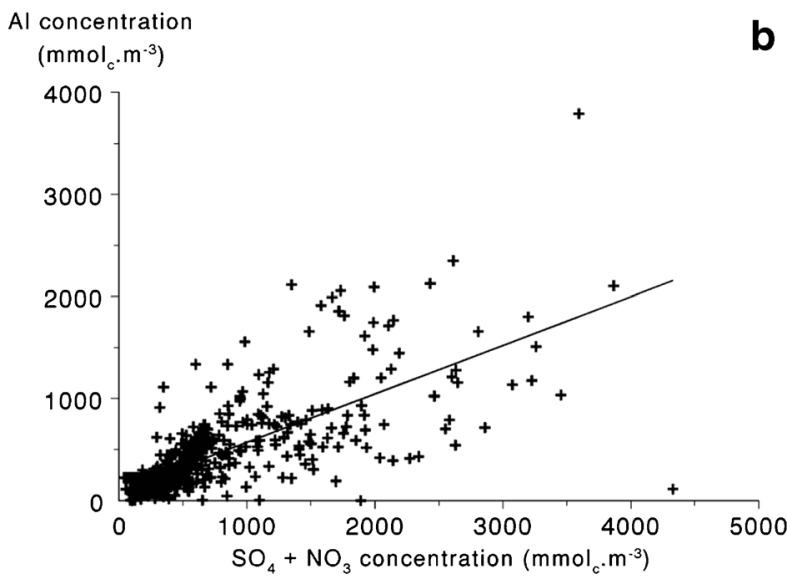

The solid line in $\mathrm{A}$ represents a regression line being equal to: $\mathrm{Al}=-95+0.74\left(\mathrm{SO}_{4}+\mathrm{NO}_{3}\right)\left(R^{2}=0.86\right)$. Source: De Vries et al. (2007) 
survey in the 1990s on the ICP Forests Level I network (Vanmechelen et al. 1997). About $44 \%$ of the number of Level I plots assessed during the first forest soil condition survey were revisited during the BioSoil survey (2326 plots), but only a limited set of 127 permanent Level II plots were investigated, with about $75 \%$ of them having historical soil data thus enabling assessment of temporal changes. Unfortunately, since methods were not always consistent, De Vos and Cools (2011) did not present any changes in soil chemistry at European scale. Unlike soil chemistry, one time monitoring data of soil solution chemistry and foliar chemistry already shows effects of atmospheric $\mathrm{N}$ and $\mathrm{S}$ deposition by elevated $\mathrm{N}$ and $\mathrm{S}$ concentrations in soil solution and forest foliage. Below the results are discussed of both one-time surveys and trends at European scale.

Soil solution chemistry At the above mentioned 121 Intensive Monitoring plots, De Vries et al. (2007) showed that in acidic sub-soils with a $\mathrm{pH}$ below 4.5, more than $80 \%$ of the variation in $\mathrm{Al}$ concentration could be explained by a variation in $\mathrm{SO}_{4}$ and $\mathrm{NO}_{3}$ concentrations (Fig. 9b), which in turn were strongly related to the deposition of $\mathrm{S}$ and $\mathrm{N}$, respectively (see Fig. 8). In addition, in coastal areas peak Al values in the range $200-800$ umol $^{-1}$ are mostly caused by sea salts blown inland by storms (Lange et al. 2006). Although $\mathrm{SO}_{4}$ is important in releasing $\mathrm{Al}$, results showed that $\mathrm{NO}_{3}$ concentrations were mostly higher, reflecting the increasing role of $\mathrm{N}$ in soil acidification. Results of the $\mathrm{Al}$ concentrations and of $\mathrm{Al} / \mathrm{Bc}$ ratios $(\mathrm{Bc}$ is $\mathrm{Ca}+\mathrm{Mg}+$ $\mathrm{K})$ in the 121 Intensive Monitoring plots in the year 2000 in different layers are given in Fig. 10. Results show a clear increase in $\mathrm{Al}$ concentration and $\mathrm{Al} / \mathrm{Bc}$ ratio going downward from the organic layer to the mineral soil (Fig. 5a, b) due to Bc uptake and elevated Al release with depth. Differences between the mineral topsoil $(0-20 \mathrm{~cm})$ and the mineral subsoil $(20-80 \mathrm{~cm})$ are smaller than the difference between the organic layer and mineral topsoil. Although different numbers of samplers at different depths influence the results, it does indicate the large impact of $\mathrm{Al}$ release and nitrification in the mineral topsoil. More details on the results are given in De Vries et al. (2003b).

Recently, Iost et al. (2012) examined trends in two soil solution parameters, i.e. the base cation/aluminium $(\mathrm{Bc} / \mathrm{Al})$ ratio and the dissolved inorganic $\mathrm{N}$ concentration, in terms of exceedances of possible critical limits for these parameters mentioned in literature (Sverdrup and Warfvinge 1993). Data were evaluated for the organic layer, mineral topsoil (0-40 cm soil depth) and mineral subsoil (below $40 \mathrm{~cm}$ soil depth) from the early 1990 s to 2006 . For the time trend analysis, they selected all plots and soil depths that provided data for at least five consecutive years. Their results showed no trends in critical limit exceedance for the $\mathrm{Bc} / \mathrm{Al}$ ratio in nearly all plots. For the $\mathrm{N}$ concentration no trends were detected in most of the plots, but in cases where a trend was detected, it was usually decreasing.

The constant $\mathrm{Bc} / \mathrm{Al}$ ratio may seem strange in view of the reduced $\mathrm{S}$ deposition. The most likely explanation is that this reduction has led to both a reduced $\mathrm{Al}$ and $\mathrm{Bc}$ concentration because of less buffering due to the decrease in potential acid deposition. Reported monitoring data for the Lehstenbach site in Germany experienced a significant decrease in acid deposition load between 1988 and 1999 and as a consequence, a significant decrease in soil solution $\mathrm{Al}$ concentration. At the same time, however, soil solution $\mathrm{Ca}$ and $\mathrm{Mg}$ decreased even stronger resulting in a decline in soil solution $\mathrm{Ca}$ to $\mathrm{Al}$ ratio (Alewell et al. 2000). Leeters et al. (2007) also found a decrease of both $\mathrm{Al}, \mathrm{K}$ and $\mathrm{Mg}$ concentration in response to a decrease in $\mathrm{S}$ and $\mathrm{N}$ deposition for 14 intensive monitoring plots In the Netherlands, in the period 1990-2001.

Foliar nutrient status Insight in the possible impact of $\mathrm{N}$ deposition on a nutritional imbalance in foliage has been derived for 109 Intensive Monitoring plots with information on both the chemical composition of the foliage and total $\mathrm{N}$ deposition. Ranges in $\mathrm{N}$ deposition at plots with a balanced and unbalanced ratio of the base cations $\mathrm{K}, \mathrm{Ca}$ or $\mathrm{Mg}$ to $\mathrm{N}$ are given in Table 2 (De Vries et al. 2003d). Criteria for deficiency (low) or excess (high) in nutrient contents and nutrient ratios are based on Stefan et al. (1997). The number of plots with a clearly unbalanced nutrition was approximately $50 \%$, with an unbalanced $\mathrm{P} / \mathrm{N}$ ratio being most common, followed by $\mathrm{Mg} / \mathrm{N}$. When considering all elements, including $\mathrm{P} \mathrm{K}, \mathrm{Ca}$ and $\mathrm{Mg}$, there was an unbalanced ratio of one or more of those elements at 57 of the 109 plots. The results indicated a larger $\mathrm{N}$ deposition at the plots with an unbalanced ratio. Considering all base cations, the median $\mathrm{N}$ deposition was $10 \mathrm{~kg} \mathrm{ha}^{-1} \mathrm{yr}^{-1}$ (range of 2-32 $\mathrm{kg} \mathrm{ha}^{-1} \mathrm{yr}^{-1}$ ) at the plots with a balanced nutrition and $21 \mathrm{~kg} \mathrm{ha}^{-1} \mathrm{yr}^{-1}$ (range of $8-$ $34 \mathrm{~kg} \mathrm{ha}^{-1} \mathrm{yr}^{-1}$ ) at the plots with an unbalanced nutrition. Results obtained on the relation between $\mathrm{N}$ 


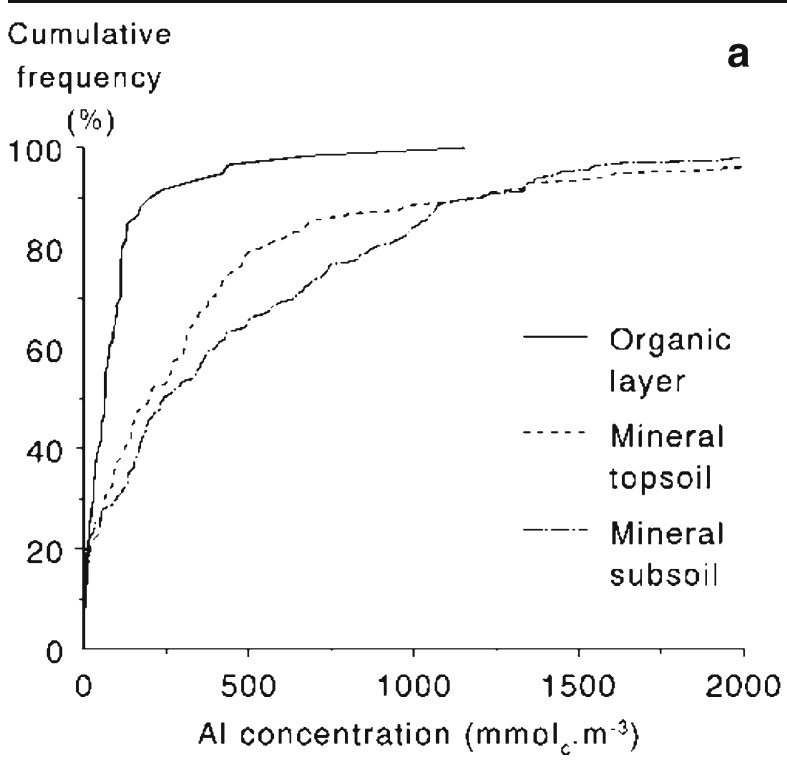

Fig. 10 Cumulative frequency distributions of the concentrations of $\mathrm{Al}$ (a) and of the ratios of $\mathrm{Al}$ against the base cations $\mathrm{Ca}, \mathrm{Mg}$ and $\mathrm{K}$ (b) in the organic layer, the mineral topsoil $(0-20 \mathrm{~cm})$ and the

contents in first year needles of Scots pine and total $\mathrm{N}$ deposition at 68 Intensive Monitoring plots in Europe (Fig. 11) indicate that $\mathrm{N}$ contents in foliage may exceed the previously mentioned critical $\mathrm{N}$ content of $1.8 \%$ related to drought and frost stress at $\mathrm{N}$ deposition levels above $20 \mathrm{~kg} \mathrm{ha}^{-1} \mathrm{yr}^{-1}$.

Regarding foliar chemistry, no trend assessments have yet been made at European scale, but results are available at country level. Leeters et al. (2007), for example, evaluated trends in foliar $\mathrm{N}$ and $\mathrm{S}$ contents in the foliage of 9 intensive monitoring plots In the Netherlands in the period 1990-2005. Their analysis included three plots for Douglas-fir (Pseudotsuga menziesii), Pine and Oak (Quercus), respectively. Results showed that $\mathrm{N}$ and $\mathrm{S}$ contents in the foliage

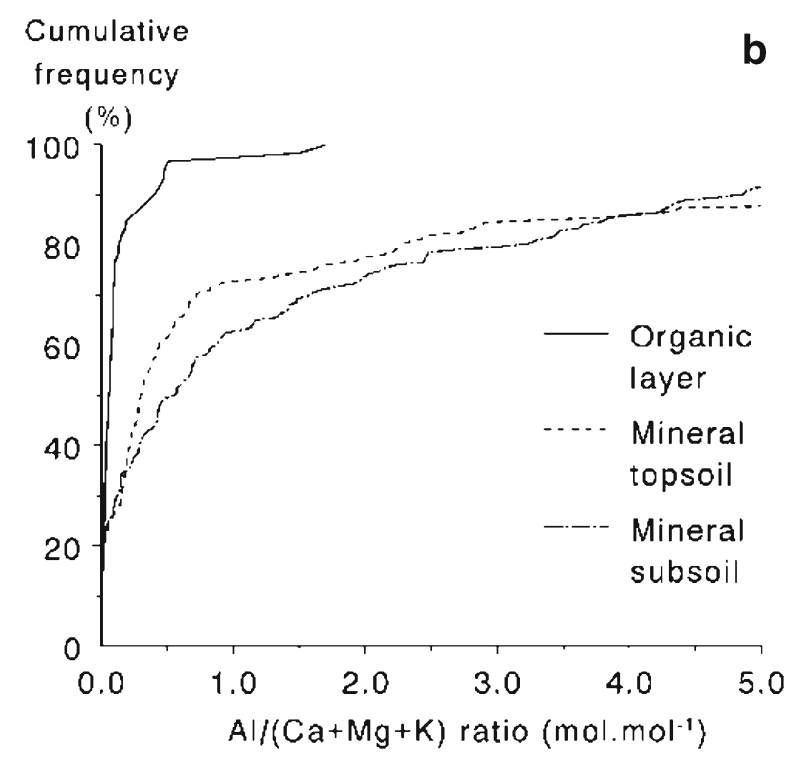

mineral subsoil (20-80 cm) of 121 Intensive Monitoring plots in the period 1996-1998. Source: De Vries et al. (2003b)

decreases significantly over this period 1990-2005 for the coniferous tree species (Douglas-fir and Pine) but no trends were found for Oak.

\section{Forest crown condition}

A possible method to explore relationships between air pollution and crown condition is by means of correlative studies, i.e. statistical analysis of data that have been collected within the framework of monitoring programmes, even without an ad-hoc experimental design (Ferretti et al. 2007a, b). This is the case of many studies carried out to evaluate relationships between air pollution and tree crown condition (Innes and Whittaker 1993;
Table 2 Ranges in $\mathrm{N}$ deposition at 109 Intensive Monitoring plots in Europe with a balanced and unbalanced ratio of $\mathrm{P}, \mathrm{K}, \mathrm{Ca}$ or $\mathrm{Mg}$ to $\mathrm{N}$

\begin{tabular}{|c|c|c|c|c|c|c|c|c|}
\hline \multirow[t]{3}{*}{ Element } & \multicolumn{8}{|c|}{$\mathrm{N}$ deposition $\mathrm{kg} \cdot \mathrm{ha}^{-1} \cdot \mathrm{yr}^{-1}$} \\
\hline & \multicolumn{4}{|l|}{ Unbalanced } & \multicolumn{4}{|l|}{ Balanced } \\
\hline & $\mathrm{Nr}$ of plots & $50 \%$ & $5 \%$ & $95 \%$ & $\mathrm{Nr}$ of plots & $50 \%$ & $5 \%$ & $95 \%$ \\
\hline $\mathrm{P}$ & 46 & 21 & 6.9 & 34 & 63 & 11 & 1.5 & 34 \\
\hline $\mathrm{K}$ & 15 & 23 & 14 & 37 & 94 & 14 & 1.7 & 33 \\
\hline $\mathrm{Ca}$ & 4 & 28 & 20 & 35 & 105 & 16 & 1.9 & 34 \\
\hline $\mathrm{Mg}$ & 24 & 22 & 11 & 35 & 85 & 13 & 1.7 & 33 \\
\hline All & 57 & 21 & 7.8 & 34 & 52 & 9.6 & 1.4 & 32 \\
\hline
\end{tabular}




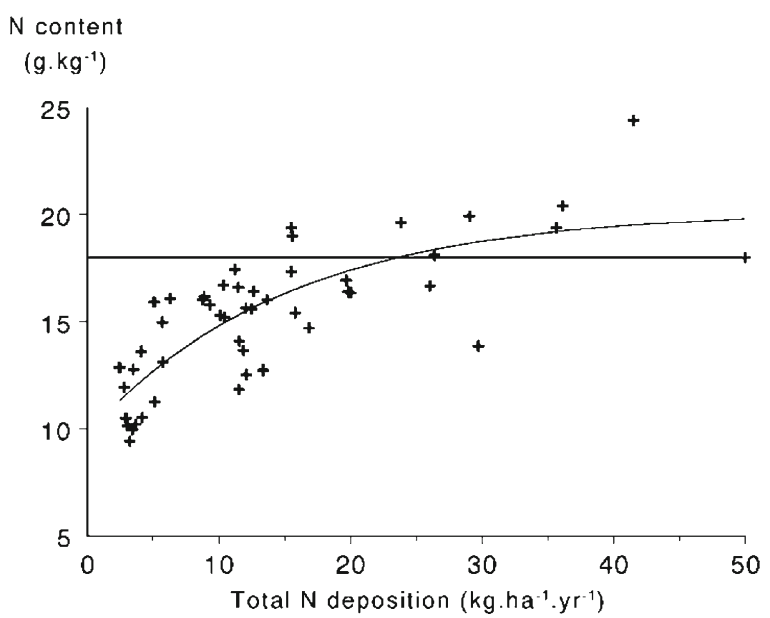

Fig. 11 Relationship between $\mathrm{N}$ contents in first year needles of Scots pine and total $\mathrm{N}$ deposition at 68 plots in Europe. Source: De Vries et al. (2003d)

Mather 1994; Dobbertin et al. 1997; Klap et al. 2000; Zierl 2002; Ferretti et al. 2003; Ozolincius et al. 2005). These studies have a number of inherent limitations (Ferretti et al. 2003; Karlsson et al. 2003; Manning 2005): (i) high variability of the forests being examined (in experimental terms: non-homogeneous experimental material), (ii) unbalanced and virtually biased allocation of plots to air pollution levels (non-random allocation of treatments, absence of replication), (iii) effects of confounding factors and covariates, (iv) absence of a true control, (v) potential inadequacy of sampling numbers for proper statistical analysis and interpretation, (vi) co-linearity between multi data, (vii) constraints in data availability and (viii) nature of the available response indicators. However, while these limitations must be taken into account at the interpretation stage, in many cases correlative studies are one of the few available options to gain an insight into the possible relationships between $\mathrm{O}_{3}$ exposure and forest conditions across wide geographical areas. In this section, we report results based on monitoring studies using a correlative approach.

\section{European scale studies}

Acid deposition Since 1986, the crown condition variables defoliation and discolouration have been monitored by assessments on permanent plots throughout
Europe, as indicators of forest health. This effort has been carried out on plots at systematically sampled locations in a grid over Europe (Level I), subjectively located intensive monitoring plots (Level II) as well as a number of additional, national sets of plots. These large data sets together with data on stress factors have been used in various research projects in order to test hypotheses on cause-effect mechanisms of forest health.

The gathering of crown condition data into international data bases, have enabled studies at the European scale. Unfortunately, although the participating countries have co-operated closely on harmonization of methods, methodological differences apparently accounted for more than $30 \%$ of the variation in defoliation on the Level I-plots in the period 1987-1997 (Klap et al. 2000). Main results of the analyses are shown in Table 3. Apart from the variable 'country', which explained variance 32 to $39 \%$ of the variation (except for Holm oak (Quercus ilex)), the most important predictor variable was age (except for $Q$. ilex), which adds 2 to $14 \%$ to the explained variance. Further step-wise completion of the statistical model revealed drought (relative transpiration) and various air pollution variables (acid deposition, air concentrations of $\mathrm{SO}_{2}$ and $\mathrm{NO}_{2}$ and AOT60 of $\mathrm{O}_{3}$ ) as significant predictors for the variation in crown condition, but the additional variance explained by the various selected predictor variables was generally very small: around $1 \%$ (Table 3 ).

However, despite this, statistical relationships have been found in a number of studies. In the above mentioned 10-year study of the Level-I plots regression analyses, significant correlations were revealed between crown condition and factors considered as natural, i.e. tree age, altitude and drought stress, while indications of effects by pathogenic fungi and insects were also found. In addition, significant relationships were also found for air pollution, most notable for $\mathrm{O}_{3}$, but also for $\mathrm{NO}_{\mathrm{x}}, \mathrm{SO}_{2}$ and acid deposition, suggesting negative effects in parts of central Europe, and in particular for deciduous tree species. The relationships were weaker for conifers, in particular for spruce (Klap et al. 1997, 2000; MüllerEdzards et al. 1997).

In a multiple regression analysis based on measured data at 222 Level II plots, De Vries et al. (2000a) found that the measured $\mathrm{SO}_{4}$ throughfall deposition was significantly related to increased defoliation of Norway spruce. In a similar data set study, De Vries et al. (2003d) used 262 Level II plots and found that 30- 
Table 3 Explained variance by country, age, altitude and environmental variables (acid deposition, relative transpiration, air concentrations of $\mathrm{SO}_{2}$ and $\mathrm{NO}_{2}$ and AOT60) by different 'best' selected statistical models (After Klap et al. 2000)

${ }^{1}$ Formulas containing 'spline' effects: $S 2=$ spline with two degrees of freedom, $S 3=$ spline with three degrees of freedom; $D($ ) means that for this meteorological variable the deviation from the 10 year average value was used

\begin{tabular}{|c|c|c|c|c|}
\hline \multirow[t]{2}{*}{ Species } & \multicolumn{3}{|l|}{$\mathrm{R}_{\text {adj }}^{2}(\%)$} & \multirow{2}{*}{$\begin{array}{l}\text { Selected predictive } \\
\text { model }^{1}\end{array}$} \\
\hline & Country & + Age & $\begin{array}{l}\text { Complete } \\
\text { model }\end{array}$ & \\
\hline Scots pine & 38.7 & 42.6 & 43.9 & $\begin{array}{l}\text { Country }+S 3(\text { Age })+\text { AcidDep }+ \\
\quad S 2\left(\text { RelTrans }_{t}\right)\end{array}$ \\
\hline Norway spruce & 38.0 & 52.2 & 54.5 & Country $+S 3$ (Age) \\
\hline $\begin{array}{l}\text { sessile or pedunculate } \\
\text { oak }\end{array}$ & 38.0 & 39.9 & 41.7 & $\begin{array}{c}\text { Country }+ \text { Spec }+S 3(\text { Age })+ \\
S 2\left(\text { RelTrans }_{\mathrm{t}-1}\right)+\left[\mathrm{NO}_{2}\right]_{\mathrm{t}}\end{array}$ \\
\hline beech & 32.5 & 34.2 & 36.6 & $\begin{array}{c}\text { Country }+S 3(\text { Age })+S 2(\text { AOT60) }+ \\
D\left(\text { RelTrans }{ }_{\text {lag }}\right)+\left[\mathrm{SO}_{2}\right]_{\mathrm{t}}+\left[\mathrm{NO}_{2}\right]_{\mathrm{t}}\end{array}$ \\
\hline Holm oak & 9.3 & $-{ }^{\dagger}$ & 15.2 & $\begin{array}{c}\text { Country }+S 3(\text { Alt })+S 2\left(\text { RelTrans }_{\mathrm{t}}\right)+ \\
{\left[\mathrm{NO}_{2}\right]_{\mathrm{t}}+S 2(\text { AOT60) }}\end{array}$ \\
\hline
\end{tabular}

$50 \%$ of the variation in defoliation in pine, spruce, oak and beech could be explained by the variation in age, soil type, precipitation, $\mathrm{N}$ and $\mathrm{S}$ deposition and foliar chemistry (Table 4). The relationship with age was generally strong, except for pine. Positive correlations between defoliation and deposition of $\mathrm{S}$ and $\mathrm{N}$ were found for spruce and oak, while this was weak or absent for pine and beech. The defoliation of spruce and oak appeared to be larger in poorly buffered sandy soils compared to well-buffered clayey soils, while relationships with other factors such as precipitation and $\mathrm{N}$ deposition was variable.
In studies by Lorenz et al. (2003) and Fischer et al. (2003), based on about 3000 Level I plots, sulphur deposition was related to either high or increasing defoliation. However, significant relationships were found for Scots pine only. In addition, the studies indicated negative effects of insect attacks, drought and age. In a 20 -year study Fischer et al. (2007) found some common, European-wide temporal variation of defoliation for most tree species, with a peak in the mid-1990s and an increase in 2003 and 2004. This might indicate that climatic conditions have a considerable influence, with particular attention to the summer droughts in the early

Table 4 Overview of predictor variables explaining defoliation of the four most represented tree species of the Intensive Monitoring Plots with the number of plots $(N)$ and the percentage accounted for $\left(R^{2}\right.$ adj $)($ after De Vries et al. 2003d)

\begin{tabular}{|c|c|c|c|c|}
\hline Variable & Scots pine & Norway spruce & Pedunculate Oak & Common beech \\
\hline Soil type & & $*$ & & \\
\hline Age $(y r)$ & + & ++ & + & ++ \\
\hline Precipitation $\left(\mathrm{mm} \cdot \mathrm{yr}^{-1}\right)$ & + & - & & \\
\hline Temperature $\left({ }^{\circ} \mathrm{C}\right)$ & & & - & - \\
\hline $\mathrm{N}$ deposition $\left(\mathrm{mol}_{\mathrm{c}} \cdot \mathrm{ha}^{-1} \cdot \mathrm{yr}^{-1}\right)$ & & - & ++ & + \\
\hline $\mathrm{S}$ deposition $\left(\mathrm{mol}_{\mathrm{c}} \cdot \mathrm{ha}^{-1} \cdot \mathrm{yr}^{-1}\right)$ & & ++ & & \\
\hline Foliar $\mathrm{N}$ content $\left(\mathrm{g} \cdot \mathrm{kg}^{-1}\right)$ & + & & & \\
\hline Foliar Ca content $\left(\mathrm{g} \cdot \mathrm{kg}^{-1}\right)$ & & - & ++ & \\
\hline $\mathrm{N}$ & 59 & 95 & 33 & 35 \\
\hline $\mathrm{R}_{\text {adj. }}^{2}$ & 21 & 35 & 44 & 48 \\
\hline
\end{tabular}

${ }^{1}$ for soil type implies that this variable was significantly related to defoliation

++ highly significant and positive correlated with response variable

+ significant and positive correlated with response variable

--highly significant and negative correlated with response variable

-significant and negative correlated with response variable 
1990s and in 2003. Until now, $\mathrm{O}_{3}$ exposure has not been included in European scale crown condition studies due to a lack of data on the European wide scale.

Ozone exposure From 2001 to 2005, Schaub and Sanz (2005) confirmed 108 symptomatic species at $136 \mathrm{EU}$ and UN-ECE/ICP Forests Level II monitoring plots across 10 countries, including 35 tree-, 27 shrub- and 46 perennial herb species (Schaub et al. 2002). Temperate plots located in humid areas such as the Italian Po Plane and Canton Ticino in southern Switzerland had the highest number of symptomatic species but no relationship was found between $\mathrm{O}_{3}$ exposure, frequency of symptomatic sites and frequency of species with symptoms (Lorenz et al. 2005).

Ferretti et al. (2007b) evaluated whether $\mathrm{O}_{3}$ is a significant predictor of defoliation of beech by relating crown defoliation data with measured $\mathrm{O}_{3}$ concentration data, collected at a number of long-term monitoring plots in France, Italy, Spain and Switzerland within the framework of the Level II monitoring network (see also Ferretti et al. 2007a; Sanz et al. 2007; Gerosa et al. 2007). Ozone seems to have had a significant role ( $p=$ 0.008 ) in determining mean defoliation of beech plots. When year-by-year deviations from predicted defoliation are considered, a possible effect of $\mathrm{O}_{3}$ was obvious only at high exposure levels. Therefore, this raises the question whether one $\mathrm{O}_{3}$ critical level to protect vegetation is appropriate for all European countries (e.g. De Santis 1999). Ozone was selected as a significant predictor of defoliation (multivariate approach) and high $\mathrm{O}_{3}$ exposure was associated with deviation from predicted crown defoliation (temporal autocorrelation approach). This suggests that $\mathrm{O}_{3}$ may have some role in determining the overall defoliation status of the sites (which however is mostly controlled by site characteristics) and in determining annual deviations from predictions (which is mostly controlled by other biotic and abiotic factors) (Ferretti et al. 2007b).

\section{National scale studies}

National scale studies relating crown condition variables to environmental conditions were mostly limited to a selected set of variables, focusing on acid deposition, $\mathrm{O}_{3}$ exposure or climatic effects, as summarized below.

Acid deposition West-Germany was the first country to carry out a nationwide assessment of crown condition, in 1983. The results of this were interpreted as evidence for air pollution effects (Schöpfer and Hradetzky 1984). This was, however, based on weak and indirect relationships such as a slightly higher defoliation in multilayered stands than in one-layered stands, because the former stand structure was believed to intercept more with the moving air masses and hence capture more air pollution. Later, based on 61 Level-II plots with 4 tree species in Germany, Seidling (2004) found no clear indication of acid deposition effects on crown condition, by showing that high defoliation during 1995-2000 was statistically related both to low concentrations of soil $\mathrm{Ca}$ as well as low concentrations of $\mathrm{SO}_{4}$ in soil solution. In a study on 1800 Level-I plots in Germany, defoliation (taken as the fraction of trees with $>25 \%$ defoliation) was positively correlated to a number of $\mathrm{S}$ variables ( $\mathrm{S}$ deposition; exceedance of critical loads of $\mathrm{S}$ and foliar $\mathrm{S}$ concentration) and foliar $\mathrm{Ca}$ concentration, while it was negatively correlated to $\mathrm{N}$ deposition (Augustin et al. 2005).

Early studies from Great Britain did not indicate negative effects of acid deposition on crown condition (Innes and Whittaker 1993; Mather et al. 1995), and the highest defoliation was found on sites having the lowest Al/BC ratios in soil water (Freer-Smith and Read 1995). However, a cause-effect relationship was considered unlikely, since plots with the highest loads of acid deposition were mainly located at high elevations exposed to mechanical damage from snow and wind (not quantified in the study) (Mather et al. 1995).

In Norway, two apparently contradictory results were found concerning the effect of acid deposition on Norway spruce defoliation. Both studies worked in southern Norway, which is a very appropriate region for correlative studies, because it contains a gradient from the highest deposition loads in Norway down to almost background values. Nellemann and Frogner (1994) found a relationship between defoliation and modelled (PROFILE) exceedance of critical loads based on about 100 Level-I plots, while Solberg and Tørseth (1997), who used a stratum of about 100 old forest officers plots, found no relationships with either deposition or soil chemical variables. While Solberg and Tørseth (1997) used standard statistical analyses methods, Nellemann and Frogner (1994) used an unusual statistical approach: Their 100 observations were first aggregated to 10 decile values, and for these 10 data points they fitted an S-shaped line and presented an $\mathrm{R}^{2}$ value of 
0.94. The S-shaped fit was the only way to resolve the fact that the plots with the highest exceedance had defoliation similar to the plots with the lowest exceedance; however, they did not provide a plausible explanation for this curve. Later, Solberg et al. (2002) carried out modelling of exceedance of critical loads of acidity for the same 100 forest officers' plots, and found the exceedance variables to not correlate with crown condition variables. Their soil solution $\mathrm{Al} / \mathrm{Ca}$ were mostly below the criterion of 1.0 , even though critical acid loads were exceeded at many plots, as calculated by the MAGIC and PROFILE models, demonstrating that modelled exceedance does not mean that unfavourable soil solution chemistry is present today but only that it might be reached in the future. Hence, exceedance may not be an appropriate variable in correlative studies searching for acid deposition effects.

Augustaitis et al. (2007) analysed Scots pine defoliation and air pollution data from 45 monitoring plots during 1994-2004 in Lithuania. During these years, air pollution decreased considerably. For example the $\mathrm{SO}_{2}$ concentrations decreased by $80 \%$. At the same time defoliation decreased considerably. This co-incidence between two decreasing trends produced positive correlations between defoliation and air pollution variables, and they concluded from this that air pollution were among the key factors affecting defoliation. However, this seems questionable as the $\mathrm{SO}_{2}$ concentrations were only in the range $1.6-6 \mu \mathrm{g} \mathrm{m}^{-3}$, which is clearly below critical levels, while it is unlikely that the ecosystem could recover from an eventual soil acidification stress during only 10 years. In addition, their hypothesis testing was questionable, since they treated all data from 45 stands during 11 consecutive years as 495 independent observations, i.e. not taking temporal autocorrelation into account.

In the Netherlands defoliation has been found to correlate mainly to tree species and age, and to a much lesser extent to foliar $\mathrm{N}$ content and $\mathrm{pH}$ of the soil solution (Hendriks et al. 1994). In a later study Hendriks et al. (2000) found that a range of factors such as deposition, climatic, stand, site and biotic factors was correlated to defoliation, however, the relationships were weak.

Ozone exposure Augustaitis and Bytnerowicz (2008) investigated the possible effect of natural and anthropogenic environmental factors on Scots pine defoliation and stem growth in Lithuania, including acid deposition and $\mathrm{O}_{3}$ exposure by applying a linear multiple regression technique. Results confirmed earlier findings that acidifying air compounds and their deposition are key factors resulting in pine defoliation changes (Augustaitis et al. 2003, 2005, 2007). They explained from $23 \%$ to $28 \%$ of the variance of residual defoliation of pine trees. The effect of peak $\mathrm{O}_{3}$ concentrations was less significant $(19.3 \%)$, however, they increased the explanation rate of defoliation residual variability by air concentration of acidifying compounds, their concentration in precipitation and deposition from 3 to $8 \%$ (Augustaitis and Bytnerowicz 2008). The findings of that study revealed that the contribution of peak $\mathrm{O}_{3}$ concentrations to the integrated impact of the other environmental factors on Scots pine defoliation and basal growth increment remain statistically significant, confirming results obtained in Finland (Utriainen and Holopainen 2000) and the Carpathian forest (Muzika et al. 2004). Also, the effects of peak $\mathrm{O}_{3}$ concentrations have higher significance for spruce trees in Norway than the mean diurnal $\mathrm{O}_{3}$ concentration or the AOT40 index in southern Sweden (Karlsson et al. 2006). Therefore, it seems that peak $\mathrm{O}_{3}$ concentration is one of the key factors affecting forest ecosystems in North-eastern and Northern Europe (Augustaitis and Bytnerowicz 2008).

With emphasis on the simulation of the local water balance, and based on forest condition data for 19831985 from the Swiss Forests Inventory (Stierlin et al. 1994), Zierl (2002) investigated possible relationships between leaf/needle loss and $\mathrm{O}_{3}$ concentrations in Switzerland by means of statistical analysis, based on the hypothesis about the possible impact of $\mathrm{O}_{3}$ on crown defoliation. All results from the temporal and spatial statistical analysis support the hypothesis that tropospheric $\mathrm{O}_{3}$ contributes to the forest decline observed during the last decades in Switzerland. However, under different climatic conditions plants might respond differently to $\mathrm{O}_{3}$, which results in regional and yearly differences in sensitivities of forest stands. Especially drought stress during the summer months can provide an effective protection from $\mathrm{O}_{3}$ damage by enforcing stomatal narrowing or even closure. At dry forest sites the risk of ozone damage even seems to be highest in years with moderate $\mathrm{O}_{3}$ concentrations, but small drought stress.

Baumgarten et al. (2009) compared exposure and flux-based indices of $\mathrm{O}_{3}$ risk at 13 Level II monitoring sites across Bavaria, Southern Germany from 
2002 to 2005. Both, the exposure-based indices AOT40 and MPOC (Maximum Permissible Ozone Concentration, Grünhage et al. 2001; Krause et al. 2005) as well as the flux-based POD indicator suggested that Bavarian forests are at risk from ozone. However, $\mathrm{O}_{3}$ visible symptoms were found only to a small extent $(<3 \%$ of total leaf area, $>1-5 \%$ of leaves) on beech trees throughout the study years, and not on all plots.

In a study dedicated on the impact of $\mathrm{O}_{3}$ on forest ecosystems in Italy, $\mathrm{O}_{3}$ was found to be a predictor of crown transparency residuals in beech sites over two consecutive years, but the variance explained amounts to less than $10 \%$ (Bussotti and Ferretti 2009). In a more recent study, Ferretti et al. (2012a) investigated the relation between defoliation data (2007-2009) collected at ICP Forests Level I $(n=15)$ and Level II $(n=1)$ plots in Trentino, Italy and site and environmental factors including $\mathrm{O}_{3}$, using multiple regression models and Linear Mixed Models (LMM). Both approaches showed that defoliation values increased with increasing frequency of reported damage (biotic and abiotic) and with decreasing level of foliar N:K. Despite the recorded high values, $\mathrm{O}_{3}$ was never reported as a significant predictor of defoliation at the plots in Trentino. These results were further confirmed for the 2000-2009 period, taking into account AOT40 and stomatal flux, at the Level II plot.

Climatic factors Weather conditions, especially drought, are major drivers for year to year variations in crown condition (e.g. Lorenz et al. 1998). In Britain, Mather et al. (1995) analysed data from 294 monitoring plots together with modelled climatic and air pollution variables between 1989 and 1992, and concluded that drought was the major factor affecting the crown condition of trees. Using multivariate analyses techniques defoliation could be attributed to soil moisture deficit and potential evapotranspiration, and the cause-effect inference was supported by observations of drought stress effects on trees in the very dry 1989 summer, particularly in southern Britain. However, drought and other factors together explained only $5-10 \%$ of the variation in defoliation. Solberg (2004) found that summer drought was followed by increases in defoliation, discolouration, more cones and mortality, working on 450 forest officers spruce plots in southeast Norway. Increased defoliation occurred the year after the drought, which was interpreted as a result of increased needle fall in the autumn after the dry summer. Seidling
(2007) studied German defoliation data from 19902004, and found increased defoliation in pine, spruce, beech and oak after dry summers, mainly with a delay of one year. The response was particularly evident after the extremely dry summer of 2003, which is also supported by the annual German forest condition report from 2004 which showed that their 20 year time series of spruce defoliation peaked in the following year 2004 (Anon 2005). In the Swiss party of the Rhone Valley, a considerable decline of Scots pine has been recorded, where $59 \%$ of the trees died from 1994 to 2004 , most of following the drought periods 1996-1998 and 20032004 (Dobbertin and Rigling 2006). Their analyses indicated that the decline was caused by an interaction between drought and mistletoe (Viscum album) infection, because the mistletoes caused increased water use. In Italy, Bussotti et al. (1995) demonstrated closely related temporal variations in litterfall and defoliation in a Holm oak monitoring plot, and concluded that summer drought was a major driver for defoliation, possibly in combination with other stress factors.

Biotic agents Many biotic agents are likely to be responsible for discolouration and defoliation, and some well-known examples of insects include Elatobius sp. lice attacks on Sitka spruce (Picea sitchensis) in Britain, oak caterpillars (Tortrix spp.) in central Europe, various moths on mountain birch (Betula pubescens) in Fennoscandia, and pine sawflies (Diprion pini and Neodiprion sertifer) in Fennoscandia. An example of fungal diseases is Gremmeniella abietina, which had an epidemic in Sweden and Norway in the years 20012003, causing considerable browning and defoliation. The extent of the disease was well described using data from grids of plot in the national forest inventory and the national forest damage inventory, even though these grids were sparse (Wulff et al. 2006). And as mentioned above, a widespread mistletoe infection apparently contributed to a Scots pine decline in the Swiss alps by causing excessive water use and more drought stress (Dobbertin and Rigling 2006).

Other stress factors In general, correlative studies often indicated a multitude of stress factors. For example, based on the longest available time series of beech and oak defoliation in several of the German federal states, Eichhorn et al. (2005) used logistic regression analyses which demonstrated that defoliation was related to a number of factors, i.e. age, crown spacing, stand 
composition, fruit bearing and insect defoliation. Tree age is often the dominating explanatory variable, as for example found in a German study: Zirlewagen et al. (2007) found that age explained 35-64\% of the variance in defoliation, which is in line with the findings of Seidling (2007). However, for cause-effect inferences, age cannot unambiguously be held responsible for defoliation, and the often identified relationship between defoliation and age may in fact represent an interaction between stress factors and age: In a study on the relationships between defoliation and age in Norway, it was demonstrated that the relationship varied from region to region, and in one region of Norway there was almost no increase in defoliation with increasing age (Solberg et al. 2009). This was the western part of Norway, where Norway spruce has been introduced, and where the soils are free from the severe root rot Heterobasidiuon annosum and where drought stress is rare due to abundant rainfall. Hence, when a large fraction of the variation in defoliation often is attributed to age, this may in fact camouflage stress affects that hit older trees harder than younger trees.

Forest growth and tree carbon sequestration

\section{European scale studies}

The influence of site and environmental factors on measured forest growth data was investigated at tree level by Laubhann et al. (2009) and at stand level by Solberg et al. (2009), using five-year growth data for the period 1994-1999 for nearly 400 intensively monitored forest plots. Evaluations focused on the influence of nitrogen and acid deposition in interaction with forest stand characteristics and weather variables. The impact of $\mathrm{O}_{3}$ exposure was not included. The study included the main tree species common beech, sessile or pedunculate oak (Quercus petraea and Q. robur), Scots pine and Norway spruce. Requirements for plot selection were different for both methods, resulting in 382 plots for the individual tree-based approach and 363 plots for the standgrowth model approach. The individual tree-based model had measured basal area increment of each individual tree as a growth response variable and tree size (diameter at breast height), tree competition (basal area of larger trees and stand density index), site factors (e.g. soil $\mathrm{C} / \mathrm{N}$ ratio, temperature), and environmental factors (e.g. temperature change compared to long-term average $\mathrm{N}$ and $\mathrm{S}$ deposition) as influencing parameters.
In the stand-growth model, stem volume increment was used as the growth response variable, after filtering out the expected growth. Expected growth was modelled as a function of site productivity, stand age and a stand density index. Relative volume growth was then calculated as actual growth in \% of expected growth. Concerning the meteorological variables temperature, precipitation, and drought the deviations from the longterm (30 years) means were used.

Results of the multivariate analyses at individual tree level, shown in Table 5, indicated a 1.2-1.5\% increase in basal area increment (coefficients varying between 0.012 and 0.015 relative increase), depending on tree species in response to a fertilizing $\mathrm{N}$ deposition effect of $1 \mathrm{~kg} \mathrm{~N} \mathrm{ha}^{-1} \mathrm{yr}^{-1}$. In this case, the response was significant for all included tree species. Laubhann et al. (2009) also showed that volume increment was proportionally related to basal area increment. Referring to a total carbon uptake for European forests of $1729 \mathrm{~kg} \mathrm{C} \mathrm{ha}^{-1} \mathrm{yr}^{-1}$ by De Vries et al. (2006), they then estimated the average response in terms of $\mathrm{C}$ sequestration between 20.7 and $25.8 \mathrm{~kg} \mathrm{C}$ per $\mathrm{kg} \mathrm{N}$, depending on tree species composition. Increasing temperature was also found to have a positive influence on forest growth, but this effect was less significant. Results of the multivariate analyses at stand level are shown in Table 6 . The results indicated roughly a $1 \%$ increase in site productivity in response to a fertilizing effect of $\mathrm{N}$ deposition of $1 \mathrm{~kg}$ of $\mathrm{N} \mathrm{ha}^{-1} \mathrm{yr}^{-1}$ for Scots pine and $2 \%$ for Norway spruce. Stronger responses were seen for $\mathrm{N}$ sensitive sites (high soil $\mathrm{C} / \mathrm{N}$ ratio), having roughly a 1.3 and $2.2 \%$ increase in growth for pine and spruce, respectively, in response to a fertilizing effect of $1 \mathrm{~kg} \mathrm{~N} \mathrm{ha}^{-1} \mathrm{yr}^{-1}$. These responses for pine and spruce were recalculated in terms of $\mathrm{C}$ sequestration, by taking the product of the measured mean annual volume increment times the mean wood density times the estimated growth increase, assuming a $\mathrm{C}$ content of $50 \%$. In converting volume increment to tree $\mathrm{C}$ changes, the increase in branches and woody roots is accounting for. The means of the modelled $\mathrm{C}$ sequestration were 19 and $38 \mathrm{~kg} \mathrm{C} / \mathrm{kg} \mathrm{N}$. More information on the approach used and results obtained is given in Solberg et al. (2009).

$\mathrm{S}$ deposition and acidic deposition both had mostly positive slopes, but these two explanatory variables were highly correlated to $\mathrm{N}$ deposition. Signs for the parameter estimates for temperature deviation gave significant positive parameter estimates for pine and spruce and partially for beech, while estimates were not significant for oak. Estimates for drought were generally 
Table 5 Multivariate regression results at tree level indicating the relative change in basal area increment per unit change in influencing factor of the four most represented tree species at the Intensive Monitoring Plots. Values for $\mathrm{N}$ deposition are given in bold. The regression results indicate the relative change in stem volume growth per unit change in influencing factor. For example, a value of 0.013 for $\mathrm{N}$ deposition implies an increase of stem growth of $1.3 \%$ per $\mathrm{kg} \mathrm{N}$ deposition Note: - implies that the effect was statistically insignificant $(p>0.05)$ (after Laubhann et al. 2009)

\begin{tabular}{lllllll}
\hline Tree species & BAL $^{1}$ & SDI & ${\mathrm{C} / \mathrm{N}_{\text {soil }}{ }^{\dagger}}$ & $\mathrm{N}_{\text {dep }}$ & Temp $^{3}$ & Temp change \\
\hline Norway spruce & -0.39 & -0.00056 & -0.023 & $\mathbf{0 . 0 1 3}$ & - & - \\
Scots pine & -0.29 & -0.00066 & - & $\mathbf{0 . 0 1 5}$ & 0.053 & - \\
Common beech & -0.16 & - & - & $\mathbf{0 . 0 1 2}$ & - & -0.064 \\
Oak & -0.38 & -0.00062 & - & $\mathbf{0 . 0 1 3}$ & 0.080 \\
\hline
\end{tabular}

${ }^{1}$ BAL is basal area of larger trees $\left(\mathrm{m}^{2} \mathrm{ha}^{-1}\right)$

${ }^{2} \mathrm{C} / \mathrm{N}$ soil is the $\mathrm{C} / \mathrm{N}$ ratio of the mineral topsoil $(0-30 \mathrm{~cm})$ and

${ }^{3}$ Temp is 30 -year average temperature $\left({ }^{\circ} \mathrm{C}\right)$

${ }^{4}$ For common beech, the effect was almost significant at $p=0.05(p=0.77)$

negative for spruce pine and beech and again mostly insignificant for oak.

\section{National scale studies}

As with crown condition, national scale studies relating forest growth to environmental conditions were mostly limited to either air quality (acid deposition and/or $\mathrm{O}_{3}$ exposure) or climatic effects, as summarized below.
Air quality The possible influence of nitrogen and acid deposition on forest growth was evaluated in a study with nationwide data-sets for Norway (Solberg et al. 2004). Results indicated a 1-2\% increase in growth per $\mathrm{kg} \mathrm{N}$ annual deposition for pine and spruce, but for beech and oak, the response was not significant. Augustaitis and Bytnerowicz (2008) investigated the impact of acid deposition and $\mathrm{O}_{3}$ exposure on both defoliation (see before) and stem growth of Scots pine stands in Lithuania. Results showed that the integrated
Table 6 Multivariate regression results at stand level indicating the relative change in stem volume growth per unit change in influencing factor of the four most represented tree species at the
Intensive Monitoring Plots. Values for $\mathrm{N}$ deposition are given in bold. Note: - implies that the effect was statistically insignificant $(p>0.05)$. (after Solberg et al. 2009)

\begin{tabular}{|c|c|c|c|c|c|c|}
\hline Tree species & Site $\operatorname{prod}^{1}$ & $\mathrm{Age}^{2}$ & $\mathrm{SDI}^{3}$ & $\mathrm{~N}_{\text {dep }}^{4}$ & Drought ${ }^{5}$ & Temp change ${ }^{6}$ \\
\hline \multicolumn{7}{|l|}{ All plots } \\
\hline Norway spruce & 0.054 & -0.005 & - & $0.020^{7}$ & - & 0.524 \\
\hline Scots pine & - & -0.017 & - & 0.010 & -0.0032 & - \\
\hline \multicolumn{7}{|l|}{ Sensitive plots } \\
\hline Norway spruce & 0.039 & -0.004 & - & 0.022 & - & 0.32 \\
\hline Scots pine & - & -0.017 & 0.001 & 0.013 & -0.002 & - \\
\hline
\end{tabular}

${ }^{1}$ Site prod is a variable for site productivity $\left(\mathrm{m}^{3} / \mathrm{ha} /\right.$ year) derived from selected European site index curves, with input variables being age and top height

${ }^{2}$ Age is stand age (yr)

${ }^{3} \mathrm{SDI}=$ stand density index (indexed number of trees/ha)

${ }^{4} \mathrm{~N}_{\text {dep }}$ is total $\mathrm{N}$ deposition $(\mathrm{kg} / \mathrm{ha} / \mathrm{yr})$

${ }^{5}$ Drought is a variable describing drought given as a relative value (in \%) to the normal (30 years mean) drought stress at each site

${ }^{6}$ Temp change is the temperature difference during the growing period compared with the 30 -year average temperature $\left({ }^{\circ} \mathrm{C}\right)$

${ }^{7}$ results from a simple linear regression gave a value of 0.020 , but in the multivariate analysis, the coefficient was not significant at $p<0.05$ 
impact of acidifying compounds and their deposition accounted for $18.5 \%$ of variability in stem increment residuals, while $\mathrm{O}_{3}$ increased the degree of the explanation by $8.7 \%-27.2 \%$.

The impact of $\mathrm{O}_{3}$ on forest ecosystems is specifically monitored and evaluated in Italy, where $\mathrm{O}_{3}$ levels are measured in 30 plots using passive samplers together with forest response parameters, including crown condition (transparency), BAI (basal area increment) and visible symptoms on spontaneous vegetation (Bussotti and Ferretti 2009). Results showed that levels of AOT40 are above the concentration-based critical level of 5 ppmh in all sites, but the evidence of impact on forest vegetation remains limited. As mentioned before, $\mathrm{O}_{3}$ was found to be a predictor of crown transparency, but the variance explained was less than $10 \%$ and the relation between BAI reduction and $\mathrm{O}_{3}$ was even less certain (Bussotti and Ferretti 2009).

As with defoliation, Ferretti et al. (2012a) also investigated the relation between growth data, reported as relative Basal Area Increment (BAI), collected in the period 2005-2009 at ICP Forests Level I $(n=15)$ and Level II $(n=1)$ plots in Trentino, Italy and site and environmental factors, using multiple regression. Results showed that relative BAI increased with foliar $\mathrm{N}: \mathrm{Mg}$ and decreased with tree diameter. As with defoliation, $\mathrm{O}_{3}$ was not a significant predictor of $\mathrm{BAI}$ at the sites in Trentino. These results were further confirmed for the 2000-2009 period, taking into account AOT40 and stomatal flux at the Level II plot. Large variations in exposure and flux did not result into consistent variation in growth. In a recent investigation carried out in Italy (Ferretti et al. 2012b), variables related to management, climate, tree health, and $\mathrm{N}$ in soil, foliage and throughfall were the most important predictors of relative growth of Level II plots.

Braun et al. (2007) applied an epidemiological analysis across 83 beech and 61 Norway spruce plots across Switzerland and associated a $7.4 \%$ reduction in shoot length with an AOT40 level of 0-10 ppm h for beech but shoot growth of Norway spruce was not affected by $\mathrm{O}_{3}$. Karlsson et al. (2006) used relative annual basal area increment of mature Norway spruce trees in southcentral Sweden during 9 years and found a decline in basal area increment of $4.6 \%$ in 19- to 35-year old Norway spruce trees that could be correlated with differences in ambient $\mathrm{O}_{3}$ exposures between years in the range of 2-9 ppm h. At the same site, $\mathrm{O}_{3}$-specific symptoms were demonstrated by means of light electron microscopy from mature Norway spruce trees (Kivimäenpää et al. 2004).

Climatic factors Various national scale studies showed that soil water availability and also temperature change was correlated with forest growth. By combining treering analysis with models for soil water availability, that had been locally calibrated, Lebourgeois et al. (2005) showed that soil water deficit, in particular in early summer, could well explain annual and early wood growth fluctuations for common beech on French Level II plots. For Norway spruce, early and latewood growth depended mainly on current summer soil water availability, while for silver fir early wood growth was also influenced by the water supply of the previous year's summer and autumn (Lebourgeois 2007). Using annual stem circumference measurements at Swiss Level II plots, a tree growth reduction was found at low altitude in 2003 as compared to the wet years 2002, while high altitude forests showed no growth change or increased growth (Jolly et al. 2005). The reason, was that at low altitude soil water availability was highly reduced in 2003 and correlated well with the observed growth reductions, while water was not limiting at high altitude (Graf Pannatier et al. 2007). At high altitude, the temperature during the summer of 2003 was increased favouring increased tree growth (Graf Pannatier et al. 2007).

Species diversity of the ground vegetation

\section{European scale studies}

Relationships between species composition of the ground vegetation and environmental factors were evaluated at 366 Intensive monitoring plots, as presented in van Dobben and de Vries (2010). Included environmental factors were: (i) site characteristics, such as climate zone, altitude, tree species and soil type, (ii) climatic data, such as temperature and precipitation, (iii) chemical soil data, including element contents in the humus layer and the mineral topsoil both in soil solid and liquid phase, and (iv) bulk deposition data of $\mathrm{NH}_{4}, \mathrm{NO}_{3}, \mathrm{SO}_{4}$, $\mathrm{Ca}, \mathrm{Mg}, \mathrm{K}, \mathrm{Na}$ and $\mathrm{Cl}$. The data used in the analysis are annual mean values over the period 1995-1999, being the period in which the ground vegetation data were assessed. Bulk deposition collected in nearby open field precipitation samplers was used as an estimator for atmospheric deposition. Although throughfall may give a better estimation of the deposition to the forest floor, 
these data were not used because they were available for a limited number of plots only. A separate analysis was carried out for these plots to check the effect of throughfall, which showed that impacts inferred on the basis of bulk deposition data were very similar to those inferred on the basis of throughfall data.

Table 7 is a summary of an ordination analysis of the first observations on all Intensive Monitoring plots available up to 1999 . Out of the $14.5 \%$ of the variance in the species abundances that can be explained by the available predictors, by far the largest part is due to the 'traditional' factors soil, climate and tree species, and only $0.6 \%$ is due to bulk deposition. $\mathrm{Na}$ and $\mathrm{NO}_{3}$ are the only ions in bulk deposition that have a significant effect, and of these two only $\mathrm{NO}_{3}$ is of anthropogenic origin. In addition, $7 \%$ variance is due to the countries themselves, probably as a result of methodological differences. It should be noted that in ordination (i.e., multivariate statistics), percentages explained variance are intrinsically low. The ordination diagram (not shown here) indicates the following main causes of variation in the vegetation (in order of decreasing importance): (1) soil fertility, (2) altitude, (3) tree species (coniferous vs. deciduous), (4) climate (oceanic vs. continental). The effect of deposition is small but statistically significant and ecologically understandable, i.e. there is a slight tendency of nitrophilic species to increase with increasing $\mathrm{NO}_{3}$ deposition.

Conclusions similar to the above, based on the same one time survey of ground vegetation data, are drawn by de Vries et al. (2003a). These authors stress the bias in monitoring results caused by methodological differences between the countries, especially if biodiversity indicators like the number of species per plot are used. Such bias can be due to differences in e.g. plot size, number

Table 7 Percentage explained variance of plant species abundances at Intensive Monitoring Plots that could be ascribed to four main groups of variables in a European and Dutch study (after Van Dobben and de Vries 2010)

\begin{tabular}{lcc}
\hline Variable group & \multicolumn{2}{c}{ Percentage explained variance } \\
\cline { 2 - 3 } & European study & Dutch study \\
\hline Soil & $5.8 \%$ & $11 \%$ \\
Climate/ hydrology & $4.9 \%$ & $3 \%$ \\
Tree species & $3.1 \%$ & $18 \%$ \\
Deposition & $0.6 \%$ & $2 \%$ \\
Total & $14.5 \%$ & $34 \%$ \\
\hline
\end{tabular}

and distance of subplots, number of yearly visits, size of the field team and experience of fieldworkers. In general, analyses based on composite measures like mean indicator values per plot or measures derive from multivariate statistics are considered more robust than analyses based on individual species. Seidling and Fischer (2008) and Seidling et al. (2008) present an analysis of a subset of the European Intensive Monitoring plots based on Ellenberg indicator values (Ellenberg et al. 1991). Also their analysis leads to the conclusion that there is a slight but statistically significant increase of nitrophilic species (i.e., an increase in mean Ellenberg nutrient indicator) with increasing nitrogen deposition.

It should be noted that small temporal shifts in the vegetation due to slow changes in soil chemistry caused by deposition will not be detected in transversal studies over a wide geographical range like the ones presented above. Van Dobben et al. (2010) presented a new analysis of the European Intensive Monitoring plots, based on repeated data on ground vegetation collected up to 2006. In this extended data set the effect of $\mathrm{N}$ deposition (in this case derived from EMEP modelling results) on ground vegetation is more pronounced than in the earlier analyses. Table 8 is a summary of an ordination analysis of the repeated observations on Intensive Monitoring plots available up to 2006, indicating the explanation of temporal changes in the vegetation and environmental variables. The total explained variance was $8.2 \%$ only, but there appeared to be a significant effect of $\mathrm{N}$ deposition, entailing a clear shift in species composition toward nitrophilic species, explaining $1.9 \%$ of the total explained variation of $8.2 \%$. This shift occurs both in

Table 8 Explained variation of the change in vegetation at Intensive Monitoring Plots, using EMEP estimates to quantify $\mathrm{N}$ deposition. Change is determined as the difference last - first relevee of each species in each plot where the time lag between the first and last relevee is $>6$ years (after Van Dobben et al. 2010)

\begin{tabular}{ll}
\hline Variable & Percentage explained variance \\
\hline $\mathrm{pH}$ & $2.2 \%$ \\
Latitude & $2.5 \%$ \\
N-total (95) & $1.9 \%$ \\
Subatlantic climate & $1.7 \%$ \\
Atlantic North climate & $1.3 \%$ \\
Tree species & $1.2 \%$ \\
Base saturation & $1.0 \%$ \\
SUM if $P<0.05$ & $8.2 \%$ \\
\hline
\end{tabular}


space (i.e., when moving from 'clean' areas to areas with a high deposition), and over time (i.e. when comparing the first and the last observation of plots where time series are available).

\section{National scale studies}

Although many countries have forest monitoring schemes at the national level, only few of them have their results published in scientific literature, the most recent examples being from the Netherlands (Van Dobben and de Vries 2010) and Norway (Økland et al. 2004). The results of these two national evaluations appear to be very comparable to the above one on the European level. The result of the study in the Netherlands is also given in Table 8, which shows that again there is a significant but small contribution of deposition to the explained variance. In this case the components of deposition with a significant effect are $\mathrm{SO}_{2}$ and $\mathrm{Mg}$. Of these, only $\mathrm{SO}_{2}$ is of anthropogenic origin, and $\mathrm{Mg}$ is probably just an indicator for the distance to the coast. The Norwegian study (Økland et al. 2004) also found the traditional factors (soil, climate, humidity) to be the most important determinants of the vegetation. In this study soil acidification due to atmospheric deposition is considered as one of the main drivers of vegetation changes (mainly a loss of species in areas with high deposition). However, this conclusion is only based on inference as the vegetation was not directly related to measured or simulated deposition.

All results referred to so far are based on the analysis of generalised indicators, i.e. derived from multivariate approaches (ordination axes) or indicator values. An alternative approach may be the analysis of the response of single species to environmental factors using logistic regression (e.g. De Vries et al. 2003d). However, with studies over a large geographical extent the distribution area of each species should also be taken into account. Failure to do so (like in the above studies) may lead to spurious results because outside its distribution area a species will be absent anyway, even if abiotic conditions are favourable. The results of such studies are therefore hard to interpret.

\section{Discussion and conclusions}

Explicit assessments of the impacts of different air quality variables (deposition of $\mathrm{N}$ and acidity and $\mathrm{O}_{3}$ exposure) and weather variables (temperature and precipitation) on forest ecosystems are difficult to derive on the basis of monitoring data because of the various interacting effects. This holds less for the impacts on forest nutrient status and soil (solution) chemistry but is specifically true for the impacts on forest health, forest growth and species diversity of the ground vegetation. Below, we discuss the strengths, weaknesses and perspectives of the European forest monitoring programme, followed by a discussion of the main results of this programme in view of those strengths and weaknesses and knowledge obtained from field and laboratory research and we end with main conclusions that can be drawn from the monitoring results.

Strengths, weaknesses and perspectives of the European forest monitoring programme

The main strength of the ICP Forests monitoring programme is the large number of variables that has been measured at each plot, the large spatial extent and the temporal coverage over the last approximately 20 years. Furthermore, compared to other monitoring programmes, ICP Forests has invested great efforts into harmonization. This has led to various manuals for the data assessment, including quality assurance and quality control procedures.

An important weakness of the forest monitoring programme is the use of non-specific response indicators, such as tree defoliation, which are affected by various interacting air quality and climate parameters. In combination with correlations between those drivers, such as those between $\mathrm{NO}_{\mathrm{x}}$ deposition and $\mathrm{O}_{3}$ exposure, this causes the problem of confounding factors in regression relations. Furthermore, despite the focus and efforts to come to harmonized approaches, there is still a lack of standardization for various assessments, specifically for crown condition and ground vegetation data, eventually causing substantial observer bias. Finally, since the programme is extremely labour intensive, there has until recently been a very strong focus on the actual field measurements all the way through to data management and data storage at the expense of actual data analyses and dissemination of results.

Despite the limitations of confounding factors due to non-specific response indicators, correlations between drivers and methodological inconsistencies, there are large potentials to explore the wealth of real-field data obtained from of large-scale long-term monitoring 
networks such as the Intensive Monitoring Level II network of ICP Forests. Potentials and perspectives, in combination with more advanced approaches and in interaction with other programmes, include:

- Integration and further data analysis: The ICP Forests Monitoring Programme in Europe has strong links to other ICPs such as ICP Modelling \& Mapping, ICP Integrated Monitoring and ICP Vegetation allowing for more integrated and interdisciplinary analyses across Europe. Another source for future potential lies in a stronger collaboration with programmes such as ICOS, EMEP, LTER, etc. Until now, integrated analyses of the data are still limited while the wealth of data allows for such an analysis, especially considering the current time coverage.

- Model validation: The monitoring data set also becomes more and more attractive for validation purposes of regional and global scale models. This is particularly true for physiological and environmental parameters describing the water, carbon and nutrient cycles.

- Introduction of new techniques and approaches: The technical advances allow more and more parameters to be monitored at higher, i.e. hourly resolution which is another great potential for model validation purposes. Furthermore, there are ideas to include not only Level II \& I but also so-called Level III (super) sites which are highly equipped long-term monitoring plots that allow integrated studies and analyses from cell to ecosystem level and validation of detailed process based models. Finally the monitoring systems can be used as a ground validation systems for remote sensing techniques, that are used to assess various forestry aspects, such as growth, crown condition and tree nutrition.

Impacts on forest ecosystems as derived from monitoring studies

\section{Nitrogen deposition effects on forest growth and plant species diversity}

The two presented European scale studies, although being different in their approaches, using a different set of plots and different methods to estimate the $\mathrm{N}$ induced carbon uptake in stem wood, resulted in similar results. In summary, the results of this wide European growth dataset in the period 1993-2000 indicated a clear fertilization effect of $\mathrm{N}$ deposition on European forests varying between approximately $20-40 \mathrm{~kg} \mathrm{C}$ per $\mathrm{kg} \mathrm{N}$ (see also De Vries et al. 2008) although higher growth responses to $\mathrm{N}$ deposition (up to $4 \%$ ) have also been observed in selected Swiss observation plots (Braun et al. 1999). The results are in line with approaches focusing on the fate of $\mathrm{N}$ in forest ecosystems (e.g. Nadelhoffer et al. 1999), results of $\mathrm{N}$ fertilizer experiments and model simulations (De Vries et al. 2009), as well meta- analysis of various $\mathrm{N}$ addition experiments. In the correlative study, S deposition and acidic deposition were also positively correlated with forest growth, but both variables were highly correlated to nitrogen deposition. It has to be realized that the overall positive effect of $\mathrm{N}$ deposition on forest growth does not preclude negative effects in extreme cases of acidification. Especially the removal of base cations from the adsorption complex of moderately acid soil may have negative effects on the long term. Lawrence et al. (2005) compared changes in soil chemistry, based on archived soil samples in 1926, 1964, and 2001, with patterns of tree growth in the same period near St. Petersburg, Russia. Results showed a depletion of exchangeable $\mathrm{Ca}$ and $\mathrm{Mg}$ in the period between 1926 and 1964 and an increase in exchangeable Al between 1964 and 2001. The onset of Al mobilization coincided with decreased diameter growth and a suppression of climate-tree growth relationships in Norway spruce, suggesting that the trees were responding to a decline in $\mathrm{Ca}$ and $\mathrm{Mg}$ availability. However, overall, the impact of acid deposition on growth does not seem to be negative at European scale.

Even though large impacts of $\mathrm{N}$ deposition on forest ground vegetation have been found in local $\mathrm{N}$ addition studies, such an effect is hard to assess in large-scale (i.e. Europe-wide or at least country-wide) monitoring studies relating variation in environmental factors, including $\mathrm{N}$ deposition, to variation in plant species diversity. These studies lead to the conclusion that factors that are considered to be key indicators for the vegetation in phyto-sociological literature (e.g. Braun-Blanquet 1964; Grime et al. 1988; Oberdorfer 1979; Ellenberg et al. 1991) are most important. These factors are soil chemistry, tree layer characteristics (most notably the tree species), climate and hydrology. Effects of $\mathrm{N}$ deposition may be significant but are always small.

A disclaimer with large-scale monitoring studies is that they may be strongly hampered by methodological 
inconsistencies, especially if they span more than one country. The European ICP Forest network has large differences in plot size and number of subplots between the countries and sometimes even within a country. Observers may have different levels of species knowledge (Ringvall et al. 2005), and in transversal studies their species knowledge tends to increase over time (De Vries et al. 2003a). Floristic views may differ per country or even per observer. Plots may be fenced to exclude the effect of grazing or unfenced, observation dates relative to the growing season may be different and there may be different number of visits per year. On the abiotic side analytical techniques may be different. Anyway evaluations over the complete geographical extent are only possible for variables that have been measured in all plots, and this requires a level of standardisation that is hardly attainable. Mosses and lichens, which are probably the best indicators for environmental conditions (Van Dobben et al. 1999), are not recorded by all countries within ICP Forests. These methodological problems make the large-scale monitoring rather insensitive, i.e. only environmental variables with a rather large effect are likely to be significant in such a study, despite large numbers of plots and a large geographical extent. Large-scale monitoring studies with repeated data, however, are likely to pick up relationships between $\mathrm{N}$ deposition and trends in plant species diversity indicators.

\section{Acid deposition effects on soil and forest condition}

Results of monitoring studies at the European scale, presented above, show that elevated $\mathrm{S}$ and $\mathrm{N}$ deposition is reflected by an increase in $\mathrm{S}$ and $\mathrm{N}$ concentration in forest foliage and elevated $\mathrm{SO}_{4}$ and $\mathrm{NO}_{3}$ concentrations in soil solution. This in turn leads to soil acidification in terms of elevated $\mathrm{Al}$ and/or Bc leaching from the forest ecosystem and increased dissolved $\mathrm{Al}$ and/or Bc concentrations. Although on average $\mathrm{N}$ deposition is higher than $\mathrm{S}$ deposition, it still leads to less cation mobilization (acidification) because $\mathrm{SO}_{4}$ generally behaves conservative, whereas $\mathrm{N}$ is strongly retained in the soil and/or denitrified. In combination with results from country scale monitoring, the studies also show that reductions in $\mathrm{S}$ and $\mathrm{N}$ deposition observed over the last 10-15 years are reflected in a decrease of foliar $\mathrm{S}$ and $\mathrm{N}$ concentrations and dissolved $\mathrm{SO}_{4}, \mathrm{NO}_{3}, \mathrm{Al}$ and $\mathrm{Bc}$ concentrations. Since both $\mathrm{Al}$ and $\mathrm{Bc}$ decrease with a decrease in acid deposition, the $\mathrm{Bc} / \mathrm{Al}$ ratio stays mostly rather constant.

Despite the impacts on forest nutrient status and soil (solution) chemistry, acidic deposition was found to explain only about $1 \%$ of the variation in crown condition on a European scale, whereas most monitoring results at national scale do not even show any convincing statistical relationship between crown condition and acid deposition or sulphur dioxide exposure. These results imply that there is no clear evidence that acid deposition negatively affects forest health, in terms of crown condition, on a large regional scale. This result is in line with the observation that defoliation tends to oscillate, which indicates that acute stress and recovery are drivers in forest health, rather than chronic air pollution stress (Landmann 1993; Mather et al. 1995; Kandler 1988). In the past several regional studies have concluded that air pollution effects on crown condition are clearly evident, but the provided evidence for this is generally weak and questionable. For example, the first nationwide assessments of crown condition in West Germany in 1983 was interpreted as evidence for air pollution effects based on weak and speculative relationships (Schöpfer and Hradetzky 1984), and the strong increase in defoliation observed in the next year was seen as evidence for the increasing damage by air pollutants, but this increase could well be explained by a change in the assessment methods (Kandler 1992).

The limited evidence of acidification impacts on forest condition from monitoring study results is in line with the earlier presented evidence that the linkage between $\mathrm{Bc} / \mathrm{Al}$ ratios and root or shoot growth found in laboratory experiments (e.g. Sverdrup and Warfvinge 1993), is generally not found in the field situation (De Wit et al. 2001a, b, 2010). Effects are even lacking in extreme situations. For example, the Uusikaarlepyy monitoring site in Finland has a very acidic soil with extremely high concentrations of inorganic Al, while the spruce trees growing there show no defoliation (Rautjärvi et al. 2002). Also in studies from moderately polluted areas North America, indications of air pollution effects on crown condition have been ruled out in favour of other factors, such as climate, stand and site condition, and pests, with special regard to drought and insect attacks (Brooks 1994; Burton et al. 1991). Despite the large body of data gathered and a widespread research effort, the effects of long-range transported acid deposition on forest health remain indecisive (e.g. Skelly and Innes 1994; Solberg and Tørseth 1997; 
Thomas et al. 2002; Solberg et al. 2004; Binkley and Högberg 1997; Kandler and Innes 1995; Klap et al. 1997).

Altogether, an evaluation of correlative studies based on European crown condition assessments together with related studies in Europe and North America, indicate that negative effects from air pollution on forests in Europe are weak or cover minor parts of Europe. Widespread, negative effects from acid deposition and soil acidification are not detectable. If occurring, negative effects of air pollution on forests in Europe seems to be local ("classical smoke damage") due to industry plumes containing high concentrations of $\mathrm{SO}_{2}$ (Lomský et al. 2002) but the extent of such damage has decreased considerably during the last 30-40 years and this $\mathrm{SO}_{2}$ damage type is today rare.

\section{Ozone exposure effects on forest condition and forest growth}

The assessment of visible $\mathrm{O}_{3}$-induced injury at monitoring sites across Europe has turned out to be a useful and inexpensive method to show spatial and temporal trends for potentially harmful $\mathrm{O}_{3}$ exposures (Sanz et al. 2007; Gerosa et al. 2007). However, species-specific differences in $\mathrm{O}_{3}$ sensitivity, differences in microclimatic conditions and species composition make it difficult to relate visible injury to $\mathrm{O}_{3}$ exposure and determine critical levels of $\mathrm{O}_{3}$ risk (Schaub and Sanz 2005). Most monitoring results both at national and European scale mostly showed a convincing statistical relationship between crown condition and $\mathrm{O}_{3}$ exposure, but generally, the effects seem to be limited. Until now, the possible impact of $\mathrm{O}_{3}$ on forest growth has hardly been evaluated in either national or European field scale monitoring studies with the exception of Augustaitis and Bytnerowicz (2008), who investigated the impact of acid deposition and $\mathrm{O}_{3}$ exposure on both defoliation and stem growth of Scots pine stands in Lithuania. Their results suggested that peak $\mathrm{O}_{3}$ concentration is one of the key factors affecting forest ecosystems in North-eastern and Northern Europe.

The limited results of correlative studies based on monitoring results do not yet confirm the hypothesis that ambient $\mathrm{O}_{3}$ is a key factor explaining spatial and temporal changes of tree crown defoliation and/or forest growth. The problem with routine forest monitoring is, however, the use on non-specific response indicators, such as tree defoliation and tree growth, which are subject to many other stressors than $\mathrm{O}_{3}$ (e.g. Percy and Ferretti 2004). Furthermore, there is generally a correlation between $\mathrm{NO}_{\mathrm{x}}$ deposition and $\mathrm{O}_{3}$ exposure, while severe drought conditions may limit $\mathrm{O}_{3}$ uptake by plants, therefore preventing the development of visible injury (Fischer et al. 2005). Consequently, field evidence of $\mathrm{O}_{3}$ effects on forests is limited and extrapolation of experimental results to the real forest condition is problematic (Ferretti et al. 2007c).

In this context, it has also to be realized that all correlative studies were made using either peak or average $\mathrm{O}_{3}$ concentrations or air quality standards such as AOT40 (Kärenlampi and Skärby 1996; Fuhrer et al. 1997). These $\mathrm{O}_{3}$ exposure metrics, however, do not account for environmental and biological variables that affect ozone uptake and plant injury (Matyssek et al. 2007a; Karlsson et al. 2007) and are thus quite inappropriate to predict ozone effects on regional scales. Until now, there are no publications relating monitored forest growth changes to changes in the phytotoxic ozone dose. This is a potential promising approach in correlative field studies. Critical levels in terms of phytotoxic ozone dose (POD) have until now been based on the results of experiments with seedlings under controlled condition (e.g. Karlsson et al. 2003) with relative reduction of biomass used as a response indicator without any results from field gradient studies or long-term monitoring studies. Such monitoring results are highly relevant since the extrapolation of results obtained from seedlings to mature trees under real forest condition has been severely challenged (Kolb and Matyssek 2003). Currently, a study is carried out in which the combined effects of climatic factors, nitrogen deposition and phytotoxic ozone dose (POD) are related to changes in basal area increment, using fifteen-year growth data for the period 1994-2009 for nearly 400 intensively monitored forest plots, as a follow up of the study by Solberg et al. (2009). Preliminary results (not yet published), however, show a large correlation between $\mathrm{N}$ and POD, thus obscuring the negative effects of cumulative $\mathrm{O}_{3}$ uptake.

\section{Climate effects on forest condition and forest growth}

Correlative studies of measured or modelled climatic and air pollution variables with monitored changes in crown condition at both European and national scale showed that climatic variables (especially drought) were generally the most significant predictors for the variation in crown condition. This result is in line with field 
studies and experimental studies, showing that drought can reduce foliage production and foliage size, increase foliage shedding, cause yellowing due to reduced foliar nutrient concentrations or cause increased attacks by pests and diseases. For example, it has been demonstrated that oak decline, which has received great attention during the last decades, is not new, but rather that it has occurred repeatedly during the past three centuries, and can be attributed to climatic extremes (winter frost, summer drought), as well as defoliating insects and pathogenic fungi, while air pollution and nutritional imbalance do not seem to be important (Thomas et al. 2002).

Both the European scale studies and various national scale studies also showed that soil water availability and drought stress are correlated with forest growth. At European scale, an increase in temperature deviation gave significant positive relationships with the growth of pine, spruce and beech, while increased drought had a significant negative impact on the growth of these tree species. The various national scale studies showed specifically a large impact of summer soil water availability on growth. The results are fully in line with the experimental observations that reduced water availability results in decreased tree growth and reduced foliage mass.

\section{Overall conclusions}

As mentioned above, there are various limitations to the analyses of large scale and long-term data sets obtained from the Intensive Monitoring Level II network of ICP Forests, such as the problem of confounding factors due to non-specific response indicators, correlations between drivers and methodological inconsistencies. Nevertheless, results of monitoring studies enabled some conclusions on large scale relations between forest ecosystem impacts and drivers of change that are in line with other field studies i.e.:

- Reductions in $\mathrm{N}$ and $\mathrm{S}$ deposition observed over the last 10-15 years are reflected in a decrease of foliar $\mathrm{N}$ and $\mathrm{S}$ contents and dissolved $\mathrm{SO}_{4}, \mathrm{NO}_{3}, \mathrm{Al}$ and $\mathrm{Bc}$ concentrations. Since both $\mathrm{Al}$ and $\mathrm{Bc}$ decrease with a decrease in acid deposition, the $\mathrm{Bc} / \mathrm{Al}$ ratio stays mostly rather constant.

- Climatic factors and in particularly drought stress, appear to be primary drivers for forest crown condition variations, while air pollution effects appear limited in time and space.
- Drought usually increases crown transparency and reduces tree growth, while temperature rise increases forest growth.

- Ozone, especially peak $\mathrm{O}_{3}$ concentrations, are related to a decrease in crown condition and growth of forest ecosystems in parts of Europe.

- Negative impacts of acid ( $\mathrm{N}$ and $\mathrm{S}$ ) deposition on crown condition and forest growth are hardly or not derived. Inversely, $\mathrm{N}$ deposition has significantly increased above ground tree growth in European forests.

- $\mathrm{N}$ deposition has negatively affected the species diversity of the ground vegetation although the impact is limited compared to traditional factors such as tree species and climate.

Acknowledgments We thankfully acknowledge Dr Richard Fischer for giving permission for the use of the Figs. 3 and 4. This review was partly funded by the strategic research program KBIV (KB-14) "Sustainable spatial development of ecosystems, landscapes, seas and regions" which is funded by the Dutch Ministry of Economic Affairs, and carried out by Wageningen University and Research centre.

\section{References}

Aber JD, Nadelhoffer KJ, Steudler P, Melillo JM (1989) Nitrogen saturation in northern forest ecosystems. Bioscience 39(6): 378-386. doi:10.2307/1311067

Aber JD, Magill A, McNulty SG, Boone RD, Nadelhoffer KJ, Downs M, Hallett R (1995) Forest biogeochemistry and primary production altered by nitrogen saturation. Water Air Soil Pollut 85(3):1665-1670. doi:10.1007/BF00477219

Aber JD, McDowell W, Nadelhoffer K, Magill A, Berntsen G, Kamakea M, McNulty S, Currie W, Rustad L, Fernandez I (1998) Nitrogen saturation in temperate forest ecosystems: hypothesis revisited. Bioscience 48:921-934

Achermann B, Bobbink R (eds) (2003) Empirical critical loads for nitrogen: Expert workshop, Berne, 11-13 November 2002. Environmental Documentation 164. Swiss Agency for the Environment, Forests and Landscape (SAEFL)

Adams HD, Guardiola-Claramonte M, Barron-Gafford GA, Villegas JC, Breshears DD, Zou CB, Troch PA, Huxman TE (2009) Temperature sensitivity of drought-induced tree mortality portends increased regional die-off under globalchange-type drought. Proc Natl Acad Sci U S A 106:70637066. doi:10.1073/pnas.0901438106

Alewell C, Manderscheid B, Gerstberger P, Matzner E (2000) Effects of reduced atmospheric deposition on soil solution chemistry and elemental contents of spruce needles in NEBavaria, Germany. J Plant Nutr Soil Sci Zeitschrift Fur Pflanzenernahrung Und Bodenkunde 163(5):509-516 
Allen CD, Breshears DD (1998) Drought-induced shift of a forestwoodland ecotone: rapid landscape response to climate variation. Proc Natl Acad Sci U S A 95(25):14839-14842

Allen CD, Macalady AK, Chenchouni H, Bachelet D, McDowell $\mathrm{N}$, Vennetier M, Kitzberger T, Rigling A, Breshears DD, Hogg EH, Gonzalez P, Fensham R, Zhang Z, Castro J, Demidova N, Lim J-H, Allard G, Running SW, Semerci A, Cobb N (2010) Drought-induced forest mortality: a global overview reveals emerging climate change risks. For Ecol Manag 259(4):660-684. doi:10.1016/j.foreco.2009.09.001

Amoriello T, Spinazzi F, Gerosa G, Costantini A, Buffoni A, Ferretti M (2003) Ozone levels and meteorological variables at the permanent monitoring plots of the CONECOFOR programme in Italy. In: Ferretti M, Bussotti F, Fabbio G, Petriccione B (eds) Ozone and forest ecosystems in Italy. Second report of the Task Force on Integrated and Combined (I\&C) evaluation of the CONECOFOR programme. Annali Istituto Sperimentale per la Selvicoltura, Special Issue, Arezzo Anno 1999 Volume 30

Anon (2005) Bericht über den Zustand des Waldes 2004. Bundesministerium für Verbraucherschutz, Ernährung und Lantwirtshaft

Aronsson A (1980) Frost hardiness in Scots pine. II Hardiness during winter and spring in young trees of different mineral status. Stud Suec 155:1-27

Aronsson A, Elowson S, Forsberg NG (1978) Torkskador på gran i Västmanland. Drought damage on spruce in south Sweden. Sveriges Skogvårdsförbunds Tidsskrift 76(6):441-456

Ashmore MR (2005) Assessing the future global impacts of ozone on vegetation. Plant Cell and Environ 28(8):949-964. doi:10. 1111/j.1365-3040.2005.01341.x

Ashmore MR, Fuhrer J (2000) New directions. Usa and abuse of the AOT40 concept. Atmos Environ 34:1157-1159

Ashmore M, Shotbolt L, Hill M, Hall J, Spurgeon D, Svendsen C, Fawehinimi J, Heywood E, Tipping E, Lofts S, Lawlor A, Jordan C (2004) Further development of an effects (critical loads) based approach for cadmium, copper, lead and zinc. Final Report, EPG

Augustaitis A, Bytnerowicz A (2008) Contribution of ambient ozone to Scots pine defoliation and reduced growth in the Central European forests: a Lithuanian case study. Environ Pollut 155(3):436-445. doi:10. 1016/j.envpol.2008.01.042

Augustaitis A, Juknys R, Kliučius A, Augustaitienè I (2003) The changes of Scots pine (Pinus sylvestris L.) tree stem and crown increment under decreased environmental pollution. Ekologia (Bratislava) 22(1):30-36

Augustaitis A, Augustaitienè I, Kliučius A, Bartkevičius E, Mozgeris G, Šopauskienè D, Eitminavičiūtė I, Arbačiauskas K, Mažeikytė R, Baužienè (2005) Forest biota under changing concentration in acidifying compounds in the air and their deposition. Balt For 11(2):84-93

Augustaitis A, Augustaitienè I, Deltuvas R (2007) Scots Pine (Pinus sylvestris L.) crown defoliation in relation to the acid deposition and meteorology in Lithuania. Water Air Soil Pollut 182(1-4):335-348. doi:10.1007/ s11270-007-9345-9

Augustin S, Bolte A, Holzhausen M, Wolff B (2005) Exceedance of critical loads of nitrogen and sulphur and its relation to forest conditions. Eur J For Res 124(4):289-300. doi:10. 1007/s10342-005-0095-1
Bacci P, Sandroni S, Ventura A (1990) Patterns of tropospheric ozone in the pre-Alpine region. Sci Tot Environ 96(3):297312. doi:10.1016/0048-9697(90)90080-E

Baker JP, Schofield CL (1982) Aluminum toxicity to fish in acidic waters. Water Air Soil Pollut 18:289-309

Baumgarten M, Werner H, Haberle KH, Emberson LD, Fabian P, Matyssek R (2000) Seasonal ozone response of mature beech trees (Fagus sylvatica) at high altitude in the Bavarian forest (Germany) in comparison with young beech grown in the field and in phytotrons. Environ Pollut 109:431-442

Baumgarten M, Huber C, Büker P, Emberson L, Dietrich H-P, Nunn AJ, Heerdt C, Beudert B, Matyssek R (2009) Are Bavarian Forests (southern Germany) at risk from groundlevel ozone? Assessment using exposure and flux based ozone indices. Environ Pollut 157:2091-2107

Berg EE, Henry JD, Fastie CL, De Volder AD, Matsuoka SM (2006) Spruce beetle outbreaks on the Kenai Peninsula, Alaska, and Kluane National Park and Reserve, Yukon Territory: relationship to summer temperatures and regional differences in disturbance regimes. For Ecol Manag 227(3): 219-232. doi:10.1016/j.foreco.2006.02.038

Bergh J, Linder S, Lundmark T, Elfving B (1999) The effect of water and nutrient availability on the productivity of Norway spruce in northern and southern Sweden. For Ecol Manag 119(1-3):51-62. doi:10.1016/S0378-1127(98)00509-X

Bigler C, Bräker OU, Bugmann H, Dobbertin M, Rigling A (2006) Drought as an inciting mortality factor in Scots pine stands of the Valais, Switzerland. Ecosystems 9(3):330-343. doi:10. 1007/S10021-005-0126-2

Binkley D, Högberg P (1997) Does atmospheric deposition threaten Swedish forests? For Ecol Manag 92(1-3):119-152. doi: 10.1016/S0378-1127(96)03920-5

Blum O, Bytnerowicz A, Manning W, Popovicheva L (1997) Ambient tropospheric ozone in the ukrainian carpathian mountains and kiev region: detection with passive samplers and bioindicator plants. Environ Pollut 98(3):299-304. doi: 10.1016/S0269-7491(97)00158-9

Bobbink R, Hettelingh J-P (2011) Review and revision of empirical critical loads and dose-response relationships. Proceedings of an expert workshop, Noordwijkerhout, 2325 June 2010. Coordination Centre for Effects, National Institue for Public Health and the Environment

Bobbink R, Hornung M, Roelofs JGM (1998) The effects of airborne nitrogen pollutants on species diversity in natural and semi-natural European vegetation. J Ecol 86(5):717-738. doi:10.1046/j.1365-2745.1998.8650717.x

Bobbink R, Hicks K, Galloway J, Spranger T, Alkemade R, Ashmore M, Bustamante M, Cinderby S, Davidson E, Dentener F, Emmett B, Erisman JW, Fenn M, Gilliam F, Nordin A, Pardo L, de Vries W (2010) Global assessment of nitrogen deposition effects on terrestrial plant diversity: a synthesis. Ecol Appl 20(1):30-59. doi:10.1890/08-1140.1

Bortier K, De Temmerman L, Ceulemans R (2000) Effects of ozone exposure in open-top chambers on poplar (Populus nigra) and beech (Fagus sylvatica): a comparison. Environ Pollut 109:509-516

Boxman AW, van Dijk HFG, Houdijk ALFM, Roelofs JGM (1988) Critical loads for nitrogen with special emphasis on ammonium. In: Nilsson J, Grennfelt P (eds) Critical loads for sulphur and nitrogen. Report from a workshop held at 
Skokloster, Sweden, 19-24 March, 1988. Miljø rapport 1988 15. Nordic Council of Ministers, København, pp 295-322

Boxman AW, van der Ven PJM, Roelofs JGM (1998) Ecosystem recovery after a decrease in nitrogen input to a Scots pine stand at Ysselsteyn, the Netherlands. For Ecol Manag 101(13):155-163

Braun-Blanquet W (1964) Pflanzensoziologie. Grundzüge der Vegetationskunde, 3rd edn. Springer, Wien

Braun S, Rihm B, Schindler C, Flückiger W (1999) Growth of mature beech in relation to ozone and nitrogen deposition: an epidemiological approach. Water Air Soil Pollut 116(1-2): 357-364. doi:10.1023/A:1005209831728

Braun S, Schindler C, Rihm B, Fluckiger W (2007) Shoot growth of mature Fagus sylvatica and Picea abies in relation to ozone. Environ Pollut 146:624-628

Braun S, Schindler C, Leuzinger S (2010) Use of sap flow measurements to validate stomatal functions for mature beech (Fagus sylvatica) in view of ozone uptake calculations. Environ Pollut 158(9):2954-2963. doi:10.1016/j.envpol. 2010.05.028

Bréda N, Huc R, Granier A, Dreyer E (2006) Temperate forest trees and stands under severe drought: a review of ecophysiological responses, adaptation processes and long-term consequences. Ann For Sci 63(6):625-644. doi:10.1051/ forest:2006042

Breshears DD, Cobb NS, Rich PM, Price KP, Allen CD, Balice RB, Romme WH, Kastens JH, Floyd ML, Belnap J, Anderson JJ, Myers OB, Meyer CW (2005) Regional vegetation die-off in response to global-change-type drought. Proc Natl Acad Sci U S A 102(42):15144-15148. doi:10.1073/ pnas.0505734102

Broadmeadow M (1998) Ozone and forest trees. New Phytol 139(1):123-125. doi:10.1046/j.1469-8137.1998. 00171.x

Brooks RT (1994) A regional-scale survey and analysis of forest growth and mortality as affected by site and stand factors and acid deposition. For Sci 40(3):543-557

Burton AJ, Pregitzer KS, Reed DD (1991) Leaf area and foliar biomass relationships in northern hardwood forests located along an $800 \mathrm{~km}$ acid deposition gradient. For Sci 37(4): 1041-1059

Bussotti F, Ferretti M (1998) Air pollution, forest condition and forest decline in Southern Europe: an overview. Environ Pollut 101(1):49-65. doi:10.1016/S0269-7491(98)00039-6

Bussotti F, Ferretti M (2009) Visible injury, crown condition, and growth responses of selected Italian forests in relation to ozone exposure. Environ Pollut 157(5):1427-1437. doi:10. 1016/j.envpol.2008.09.034

Bussotti F, Ferretti M, Cozzi A, Grossoni P, Bottacci A, Tani C (1995) Crown status of holm oak (Quercus ilex L.) trees as related to phenology and environmental stress. Water Air Soil Pollut 85(3):1269-1274. doi:10.1007/BF00477156

Bussotti F, Pancrazi M, Matteucci G, Gerosa G (2005) Leaf morphology and chemistry in Fagus sylvatica (beech) trees as affected by site factors and ozone: results from CONECOFOR permanent monitoring plots in Italy. Tree Physiol 25(2):211-219. doi:10.1093/treephys/25.2.211

Bytnerowicz A, Omasa K, Paoletti E (2007) Integrated effects of air pollution and climate change on forests: a northern hemisphere perspective. Environ Pollut 147(3):438-445. doi:10. 1016/j.envpol.2006.08.028
Calatayud V, Cerveró J, Calvo E, Garcia-Breijo F-J, ReigArmiñana J, Sanz MJ (2011) Responses of evergreen and deciduous Quercus species to enhanced ozone levels. Environ Pollut 159(1):55-63. doi:10.1016/j.envpol.2010. 09.024

Carnicer J, Coll M, Ninyerola M, Pons X, Sanchez G, Penuelas J (2011) Widespread crown condition decline, food web disruption, and amplified tree mortality with increased climate change-type drought. Proc Natl Acad Sci U S A 108:14741478. doi:10.1073/pnas. 1010070108

Chappelka AH, Samuelson LJ (1998) Ambient ozone effects on forest trees of the eastern United States: a review. New Phytol 139(1):91-108. doi:10.1046/j.1469-8137.1998.00166.x

Christensen JH, Christensen OB (2003) Climate modelling: severe summertime flooding in Europe. Nature 421(6925):805-806. doi: $10.1038 / 421805$ a

Christiansen E (1992) After-effects of drought did not predispose young Picea abies to infection by the bark beetle-transmitted blue-stain fungus Ophiostoma polonicum. Scand J For Res 7(1-4):557-569. doi:10.1080/02827589209382747

Christiansen E, Nilsen P (1990) Effekter av tørke og nitrogen. Aktuelt fra Skogforsk 5:18-29

Ciais P, Reichstein M, Viovy N, Granier A, Ogee J, Allard V, Aubinet M, Buchmann N, Bernhofer C, Carrara A, Chevallier F, de Noblet N, Friend AD, Friedlingstein P, Grunwald T, Heinesch B, Keronen P, Knohl A, Krinner G, Loustau D, Manca G, Matteucci G, Miglietta F, Ourcival JM, Papale D, Pilegaard K, Rambal S, Seufert G, Soussana JF, Sanz MJ, Schulze ED, Vesala T, Valentini R (2005) Europewide reduction in primary productivity caused by the heat and drought in 2003. Nature 437:529-533. doi:10.1038/ nature 03972

Cronan CS, Grigal DF (1995) Use of Ca/Al ratios as indicators of stress in forest ecosystems. J Environ Qual 24(2):209-226. doi:10.2134/jeq1995.00472425002400020002x

Dambrine E, Carisey N, Pollier B, Granier A (1993) Effects of drought on the yellowing status and the dynamics of mineral elements in the xylem sap of declining spruce (Picea abies L.). Plant Soil 150(2):303-306. doi:10.1007/BF00013028

De Leeuw F, Bogman F (2001) Air pollution by ozone in europe in summer 2001. Overview of exceedances of EC ozone threshold values during the summer season April-August 2001. EEA Topic Report 13/2001. European Environmental Agency, Copenhagen

De Santis F (1999) New directions: will a new European vegetation ozone standard be fair to all European Countries? Atmos Environ 33(23):3873-3874. doi:10.1016/S1352-2310(99) 00110-7

De Visser PHB (1994) Growth and nutrition of Douglas-fir, Scots pine and pedunculate oak in relation to soil acidification. $\mathrm{PhD}$ Thesis, Wageningen Agricultural University, Wageningen, The Netherlands

De Vos B, Cools N (2011) Second European Forest Soil Condition Report. Volume I: Results of the BioSoil Soil Survey. Research Institute for Nature and Forest, Brussel

De Vries W, Klap JM, Erisman JW (2000a) Effects of environmental stress on forest crown condition in Europe. Part I: Hypotheses and approach to the study. Water Air Soil Pollut 119(1-4):317-333. doi:10.1023/A:1005157509454

De Vries W, Reinds GJ, van Kerkvoorde MA, Hendriks CMA, Leeters EEJM, Gross CP, Voogd JCH, Vel EM (2000b) 
Intensive Monitoring of Forest Ecosystems in Europe. Technical Report 2000. UN/ECE, EC, Forest Intensive Monitoring Coordinating Institute

De Vries W, Reinds GJ, Posch M, Sanz MJ, Krause GHM, Calatayud V, Renaud JP, Dupouey JL, Sterba H, Gundersen P, Voogd JCH, Vel EM (2003a) Intensive monitoring of forest ecosystems in Europe. Technical Report 2003. UN/ECE and EC, Forest Intensive Monitoring Coordinating Institute, Geneva and Brussels

De Vries W, Reinds GJ, Van der Salm C, van Dobben H, Erisman JW, de Zwart D, Bleeker A, Draaijers G-PJ, Gundersen P, Vel EM, Haussmann T (2003b) Results on nitrogen impacts in the EC and UN/ECE ICP Forests programme. In: Achermann B, Bobbink R (eds) Empirical critical Loads for Nitrogen. Proceedings of an Expert Workshop in Berne, Switzerland, November 11-13. Swiss Agency for the Environment, Forests and Landscape (SAEFL) Environmental Documentation 164, pp 199-207

De Vries W, Reinds GJ, Vel E (2003c) Intensive monitoring of forest ecosystems in Europe: 2. Atmospheric deposition and its impacts on soil solution chemistry. For Ecol Manag 174(1-3):97-115. doi:10.1016/S0378-1127(02)00030-0

De Vries W, Vel E, Reinds GJ, Deelstra H, Klap JM, Leeters EEJM, Hendriks CMA, Kerkvoorden M, Landmann G, Herkendell J, Haussmann T, Erisman JW (2003d) Intensive monitoring of forest ecosystems in Europe: 1. Objectives, set-up and evaluation strategy. For Ecol Manag 174(1-3):77-95. doi:10.1016/ S0378-1127(02)00029-4

De Vries W, Reinds GJ, Gundersen P, Sterba H (2006) The impact of nitrogen deposition on carbon sequestration in European forests and forest soils. Glob Chang Biol 12(7):1151-1173. doi:10.1111/j.1365-2486.2006.01151.x

De Vries W, van der Salm C, Reinds GJ, Erisman JW (2007) Element fluxes through European forest ecosystems and their relationships with stand and site characteristics. Environ Pollut 148(2):501-513. doi:10.1016/j.envpol.2006.12.001

De Vries W, Solberg S, Dobbertin M, Sterba H, Laubhann D, Reinds GJ, Nabuurs GJ, Gundersen P, Sutton MA (2008) Ecologically implausible carbon response? Nature 451:E1E3. doi:10.1038/nature06579

De Vries W, Solberg S, Dobbertin M, Sterba H, Laubhann D, van Oijen M, Evans C, Gundersen P, Kros J, Wamelink GWW, Reinds GJ, Sutton MA (2009) The impact of nitrogen deposition on carbon sequestration by European forests and heathlands. For Ecol Manag 258(8):1814-1823. doi:10.1016/j. foreco.2009.02.034

De Vries W, Wamelink GWW, van Dobben H, Kros J, Reinds GJ, Mol-Dijkstra JP, Smart SM, Evans CD, Rowe EC, Belyazid S, Sverdrup HU, van Hinsberg A, Posch M, Hettelingh JP, Spranger T, Bobbink R (2010) Use of dynamic soil-vegetation models to assess impacts of nitrogen deposition on plant species composition: an overview. Ecol Appl 20(1):60-79. doi:10.1890/08-1019.1

De Wit HA, Mulder J, Nygaard PH, Aamlid D (2001a) Testing the aluminium toxicity hypothesis: a field manipulation experiment in mature spruce forest in Norway. Water Air Soil Pollut 130(1-4):995-1000. doi:10.1023/A:1013939725573

De Wit HA, Mulder J, Nygaard PH, Aamlid D, Huse M, Kortnes E, Wollebæk G, Brean R (2001b) Aluminium: the need for a re-evaluation of its toxicity and solubility in mature spruce stands. Water Air Soil Pollut Focus 1(1-2):103-118. doi:10. 1023/A:1011504629547

De Wit HA, Eldhuset T, Mulder J (2010) Dissolved Al reduces Mg uptake in Norway spruce forest: Results from a long-term field manipulation experiment in Norway. For Ecol Manag 259(10):2072-2082. doi:10.1016/j.foreco.2010.02.018

Derwent RG, Stevenson DS, Collins WJ, Johnson CE (2004) Intercontinental transport and the origins of the ozone observed at surface sites in Europe. Atmos Environ 38:18911901

Dise NB, Matzner E, Forsius M (1998a) Evaluation of organic horizon $\mathrm{C}: \mathrm{N}$ ratio as an indicator of nitrate leaching in conifer forests across Europe. Environ Pollut 102(Supp 1):453-456. doi:10.1016/S0269-7491(98)80068-7

Dise NB, Matzner E, Gundersen P (1998b) Synthesis of nitrogen pools and fluxes from European forest ecosystems. Water Air Soil Pollut 105(1-2):143-154. doi:10.1023/ A:1005068501864

Dise NB, Matzner E, Armbruster M, MacDonald JA (2001) Aluminium output fluxes from forest ecosystems in Europe: a regional assessment. J Environ Qual 30(5):1747-1756. doi: 10.2134/jeq2001.3051747x

Dise NB, Rothwell JJ, Gauci V, van der Salm C, de Vries W (2009) Predicting nitrate leaching in European forests using two independent databases. Sci Tot Environ 407(5):17981808. doi:10.1016/j.scitotenv.2008.11.003

Dizengremel P (2001) Effects of ozone on the carbon metabolism of forest trees. Plant Physiol 39(9):729-742. doi:10.1016/ S0981-9428(01)01291-8

Dobbertin M (2005) Tree growth as indicator of tree vitality and of tree reaction to environmental stress: a review. Eur J For Res 124(4):319-333. doi:10.1007/ s10342-005-0085-3

Dobbertin M, Rigling A (2006) Pine mistletoe (Viscum album ssp. austriacum) contributes to Scots pine (Pinus sylvestris) mortality in the Rhone valley of Switzerland. For Pathol 36(5): 309-322. doi:10.1111/j.1439-0329.2006.00457.x

Dobbertin M, Ghosh S, Innes JL (1997) National reports: Switzerland. In: Müller-Edzards C, De Vries W, Erisman JW (eds) Ten years of monitoring forest condition in Europe. EC-UN/ECE, Brussels, pp 120-124

Dobbertin M, Eilmann B, Bleuler P, Giuggiola A, Pannatier EG, Landolt W, Schleppi P, Rigling A (2010) Effect of irrigation on needle morphology, shoot and stem growth in a droughtexposed Pinus sylvestris forest. Tree Physiol 30(3):346-360. doi:10.1093/Treephys/Tpp123

EC-UN/ECE (2007) The condition of forests in Europe. 2007 Executive Report. EC, UN/ECE, Hamburg, Geneva

Eichhorn J, Icke R, Isenberg A, Paar U, Schönfelder E (2005) Temporal development of crown condition of beech and oak as a response variable for integrated evaluations. Eur J For Res 124(4):335-347. doi:10.1007/s10342-005-0097-z

Ellenberg H Jr (1985) Veränderungen der Flora Mitteleuropas unter dem Einfluss von Düngung und Immissionen. Schweiz Z Forstwes 136:19-39

Ellenberg H, Weber HE, Düll R, Wirth V, Werner W, Paulißen D (1991) Indicator values of plants in Central Europe. Erich Goltze, Göttingen

Emberson LD, Ashmore MR, Cambridge HM, Simpson D, Tuovinen JP (2000) Modelling stomatal ozone flux across Europe. Environ Pollut 109(3):403-414 
Ferretti M, Fischer RF (eds) (2013) Methods for terrestrial investigations in Europe with an overview of North America and Asia. Developments in environmental science, vol Volume 12: Forest Monitoring, 1st Edition edn. Elsevier Publishers, ISBN: 9780080982229

Ferretti M, Innes JL, Jalkanen R, Saurer M, Schäffer J, Spiecker H, von Wilpert K (2002) Air pollution and environmental chemistry - what role for tree-ring studies? Dendrochronologia 20(1-2):159-174. doi:10.1078/1125-7865-00014

Ferretti M, Gerosa G, Bussotti F, Fabbio G (2003) Ozone exposure, crown transparency and basal area increment at the permanent monitoring plots of the CONECOFOR programme in Italy. In: Ferretti M, Bussotti F, Fabbio G, Petriccione B (eds) Ozone and Forest Ecosystems in Italy. Second report of the Task Force on Integrated and Combined (I\&C) evaluation of the CONECOFOR programme. Annali Istituto Sperimentale per la Selvicoltura, Special Issue, Arezzo Anno 1999 Volume 30 - Supplemento 1 2003. pp $107-120$

Ferretti M, Bussotti F, Calatayud V, Schaub M, Kräuchi N, Petriccione B, Sanchez-Peña G, Sanz MJ, Ulrich E (2007a) Ozone and forests in South-Western Europe. Environ Pollut 145(3):617-619. doi:10.1016/j.envpol.2006.02.026

Ferretti M, Bussotti F, Calderesi M (2007b) Ozone exposure, defoliation of beech (Fagus sylvatica L.) and visible foliar symptoms on native plants in selected plots of South-Western Europe. Environ Pollut 145(3):644-651. doi:10.1016/j. envpol.2006.02.028

Ferretti M, Fagnano M, Amoriello T, Badiani M, Ballarin-Denti A, Buffoni A, Bussotti F, Castagna A, Cieslik S, Costantini A, De Marco A, Gerosa G, Lorenzini G, Manes F, Merola G, Nali C, Paoletti E, Petriccione B, Racalbuto S, Rana G, Ranieri A, Tagliaferri A, Vialetto G, Vitale M (2007c) Measuring, modelling and testing ozone exposure, flux and effects on vegetation in southern European conditions-What does not work? A review from Italy. Environ Pollut 146(3): 648-658. doi:10.1016/j.envpol.2006.05.012

Ferretti M, Bacaro G, Brunialti G, Cristofolini F, A.Cristofori, Frati L, Maccherini S, Gottardini E (2012a) Defogliazione ed accrescimento degli alberi nei siti di monitoraggio delle foreste in Trentino: relazione con fattori stazionali, nutrizionali, eteorologici ed ozono nel periodo 20052011. In: E. Gottardini FC, A. Cristofori, M. Confalonieri, M. Ferretti (ed) Ozono e foreste in Trentino. Risultati del progetto Ozone EFFORT 20072011. FEM-CRI, p 144

Ferretti M, Marchetto A, Bussotti F, Calderisi M, Canullo R, Carnicelli S, Cecchini G, Fabbio G, Bertini G, Matteucci G, De Cinti B, Pompei E, Salvati L (2012b) Nitrogen deposition and Critical Load exceedance: effects on health, growth and diversity of forest vegetation in Italy. In: Book of Abstracts, Conference "Biological Reactions of Forests to Climate Change and Air Pollution". Kaunas, Lithuania, 18-27 May, 2012. p 53

Ferretti M, Beuker E, Calatayud V, Canullo R, Dobbertin M, Eichhorn J, Neumann M, Roskams P, Schaub M (2013) Data quality in field surveys: Methods and results for tree condition, phenology, growth, plant diversity and foliar injury due to ozone. In: Ferretti M, Fischer R (eds) Forest monitoring, Vol 12, developments in environmental science. Elsevier, UK, pp 397-414
Fiala J, Cernikovsky L, de Leeuw F, Livorova H (2002) Air pollution by ozone in Europe in summer 2002. Overview of exceedances of EC ozone threshold values during the summer season April-August 2002. EEA Topic Report 6/2002. European Environmental Agency, Copenhagen

Fiala J, Cernikovsky L, de Leeuw F, Kurfuerst P (2003) Air pollution by ozone in Europe in summer 2003. Overview of Exceedances of EC Ozone Threshold Values During the Summer Season AprileAugust 2003 and Comparison with Previous Years. EEA Topic Report 3/2003. European Environmental Agency, Copenhagen

Fischer R, de Vries W, Beuker E, Calatayud V, Fürst A, Häberle K-H, Haussmann T, Karnosky DF, Krause GHM, Gundersen P, Lorenz M, Luyssaert S, Matyssek R, Mayer F-J, Meining S, Mues V, Neville P, Percy KE, Posch M, Preusler T, Reinds GJ, Renaud JP, Sanze MJ, Schultze ED, Vel E (2003) The condition of forests in Europe, Executive report 2003. UN/ ECE and EC, Federal Research Centre for Forestry and Forest Products (BFH), Geneva and Brussels

Fischer R, Bastrup-Birk A, Becker R, Calatayud V, Dise N, Dobbertin M, Graf-Pannatier E, Gundersen P, Haußman T, Hildingsson A, Lorenz M, Müller J, Mues V, Pavlenda P, Petriccione B, Raspe S, Sanchez-Peña G, Sanz MJ, Ulrich E, Volz R, Wijk S (2005) The Condition of Forests in Europe. 2005 Executive Report. UNECE, Geneva

Fischer R, Mues V, Ulrich E, Becher G, Lorenz M (2007) Monitoring of atmospheric deposition in European forests and an overview on its implication on forest condition. Appl Geochem 22(6):1129-1139. doi:10.1016/j.apgeochem.2007. 03.004

Fischer R, Granke O, Chirici G, Meyer P, Seidling W, Stofer S, Corona P, Marchetti M, Travaglini D (2009) Background, main results and conclusions from a test phase for biodiversity assessments on intensive forest monitoring plots in Europe. iForest 2:67-74. doi:10.3832/ifor0493-002

Fischer R, Lorenz M, Granke O, Mues V, Iost S, van Dobben H, Reinds GJ, de Vries W (2010) Forest Condition in Europe, 2010. ICP Forests, Hamburg

Flückiger W, Braun S (1998) Nitrogen deposition in Swiss forests and its possible relevance for leaf nutrient status, parasite attacks and soil acidification. Environ Pollut 102(Supp 1): 69-76. doi:10.1016/S0269-7491(98)80017-1

Forster P, Ramaswamy V, Artaxo P, Berntsen T, Betts R, Fahey DW, Haywood J, Lean J, Lowe DC, Myhre G, Nganga J, Prinn R, Raga G, Schulz M, van Dorland R (2007) Changes in atmospheric constituents and in Radiative Forcing. In: Solomon S, Qin D, Manning M et al. (eds) Climate change 2007: The Physical Science Basis. Contribution of Working Group I to the Fourth Assessment Report of the Intergovernmental Panel on Climate Change. Cambridge University Press, Cambridge, UK/New York, NY, USA, pp 129-234

Fowler D, Cape N, Coyle M, Flechard C, Kuylenstierna J, Hicks K, Derwent D, Johnson C, Stevenson D (1999) The global exposure of forests to air pollutants. Water Air Soil Pollut 116(1-2):5-32. doi:10.1023/A:1005249231882

Franklin O, Högberg P, Ekblad A, Ågren GI (2003) Pine forest floor carbon accumulation in response to $\mathrm{N}$ and $\mathrm{PK}$ additions 
- bomb ${ }^{14} \mathrm{C}$ modelling and respiration studies. Ecosystems 6(7):644-658. doi:10.1007/s10021-002-0149-x

Freer-Smith PH, Read DB (1995) The relationship between crown condition and soil solution chemistry in oak and Sitka spruce in England and Wales. For Ecol Manag 79(3):185-196. doi: 10.1016/0378-1127(95)03614-8

Frei C, Scholl R, Fukutome S, Schmidli J, Vidale PL (2006) Future change of precipitation extremes in Europe: intercomparison of scenarios from regional climate models. J Geophys ResAtmos 111(D06105):22. doi:10.1029/2005jd005965

Fuhrer J, Skärby L, Ashmore MR (1997) Critical levels for ozone effects on vegetation in Europe. Environ Pollut 97(1-2):91106

Gauss M, Myhre G, Pitari G, Prather MJ, Isaksen ISA, Berntsen TK, Brasseur GP, Dentener FJ, Derwent RG, Hauglustaine DA, Horowitz LW, Jacob DJ, Johnson M, Law KS, Mickley LJ, Müller JF, Plantevin PH, Pyle JA, Rogers HL, Stevenson DS, Sundet JK, van Weele M, Wild O (2003) Radiative forcing in the 21 st century due to ozone changes in the troposphere and the lower stratosphere. J Geophys Res 108(D9):4292. doi:10.1029/2002JD002624

Gauss M, Myhre G, Isaksen ISA, Grewe V, Pitari G, Wild O, Collins WJ, Dentener FJ, Ellingsen K, Gohar LK, Hauglustaine DA, Iachetti D, Lamarque F, Mancini E, Mickley LJ, Prather MJ, Pyle JA, Sanderson MG, Shine KP, Stevenson DS, Sudo K, Szopa S, Zeng G (2006) Radiative forcing since preindustrial times due to ozone change in the troposphere and the lower stratosphere. Atmos Chem Phys 6(3):575-599. doi:10.5194/acp-6-5752006

Gerosa G, Ferretti M, Bussotti F, Rocchini D (2007) Estimates of ozone AOT40 from passive sampling in forest sites in SouthWestern Europe. Environ Pollut 145(3):629-635. doi:10. 1016/j.envpol.2006.02.030

Gerosa G, Marzuoli R, Desotgiu R, Bussotti F, Ballarin-Denti A (2008) Visible leaf injury in young trees of Fagus sylvatica L. and Quercus robur L. in relation to ozone uptake and ozone exposure. An Open-Top Chambers experiment in South Alpine environmental conditions. Environ Pollut 152:274 284. doi:10.1016/j.envpol.2007.06.045

Gerosa G, Marzuoli R, Desotgiu R, Bussotti F, Ballarin-Denti A (2009) Validation of the stomatal flux approach for the assessment of ozone visible injury in young forest trees. Results from the TOP (transboundary ozone pollution) experiment at Curno, Italy. Environ Pollut 157:1497-1505

Gilliam FS (2006) Response of the herbaceous layer of forest ecosystems to excess nitrogen deposition. J Ecol 94(6): 1176-1191. doi:10.1111/j.1365-2745.2006.01155.x

Gitlin AR, Sthultz CM, Bowker MA, Stumpf S, Paxton KL, Kennedy K, Munoz A, Bailey JK, Whitham TG (2006) Mortality gradients within and among dominant plant populations as barometers of ecosystem change during extreme drought. Conserv Biol 20(5):1477-1486. doi:10.1111/j. 1523-1739.2006.00424.x

Graf Pannatier E, Dobbertin M, Schmitt M, Thimonier A, Waldner P (2007) Effects of the drought 2003 on forests in Swiss level II plots. Schriftenreihe der Forstlichen Fakultät Göttingen und der Nordwestdeutschen Forstlichen Versuchsanstalt

Grime JP, Hodgson GJ, Hunt R (1988) Comparative plant ecology; a functional approach to common British species. Unwin Hyman, London
Gruber F (1990) Verzweigungssystem, Benadelung und Nadelfall der Fichte (Picea abies). Birkhäuser, Basel

Grünhage L, Krause GHM, Köllner B, Bender J, Weigel H-J, Jäger H-J, Guderian R (2001) A new flux-orientated concept to derive critical levels for ozone to protect vegetation. Environ Pollut 111(3):355-362

Grünhage L, Matyssek R, Haberle KH, Wieser G, Metzger U, Leuchner M, Menzel A, Dieler J, Pretzsch H, Grimmeisen W, Zimmermann L, Raspe S (2012) Flux-based ozone risk assessment for adult beech forests. Trees-Struct Funct 26: 1713-1721. doi:10.1007/s00468-012-0716-5

Guderian R (1985) Air pollution by photochemical oxidants, formation, transport, control and effects on plants. Springer Verlag, Berlin

Gundersen P, Callesen I, de Vries W (1998) Nitrate leaching in forest ecosystems is related to forest floor $\mathrm{C} / \mathrm{N}$ ratios. Environ Pollut 102(1):403-407. doi:10. 1016/S0269-7491(98)80060-2

Hanson PJ, Weltzin JF (2000) Drought disturbance from climate change: response of United States forests. Sci Tot Environ 262(3):205-220. doi:10.1016/S00489697(00)00523-4

Heiniger U, Schmid M (1986) Nadelfall der Fichte. Untersuchungen zum jahreszeitlichen Verlauf des Nadelfalls und zum Vorkommen von Schüttepilzen im Kanton Zürich. Schweiz Z Forstwes 137(2):157-162

Heiniger U, Schmid M (1989) Association of Tiarosporella parca with needle reddening and needle cast in Norway spruce. Eur J For Path 19(3):144-150. doi:10.1111/j.1439-0329.1989. tb00245.x

Hendriks CMA, de Vries W, van den Burg J (1994) Effects of acid deposition on 150 forest stands in the Netherlands. 2. Relationships between forest vitality characteristics and the chemical composition of foliage, humus layer, mineral soil and soil solution. Staring Centre Report. Winand Staring Centre for Integrated Soil and Water Research., Wageningen; Netherlands

Hendriks CMA, Olsthoorn AFM, Klap JM, Goedhart PW, Oude Voshaar JH, Bleeker A, de Vries F, van der Salm C, Voogd JCH, de Vries W, Wijdeven SMJ (2000) Relationships between crown condition and its determining factors in the Netherlands for the period 1984 to 1994. Alterra rapport. Alterra, Wageningen (Netherlands)

Högberg P, Fan H, Quist M, Binkley D, Tamm CO (2006) Tree growth and soil acidification in response to 30 years of experimental nitrogen loading on boreal forest. Glob Chang Biol 12(3):489-499. doi:10.1111/j. 1365-2486.2006.01102.x

Hutchinson TC, Bozic L, Munoz-Vega G (1986) Responses of five species of conifer seedlings to aluminum stress. Water Air Soil Pollut 31(1-2):283-294. doi:10.1007/BF00630844

Hyvönen R, Persson T, Andersson S, Olsson B, Ågren GI, Linder $\mathrm{S}$ (2008) Impact of long-term nitrogen addition on carbon stocks in trees and soils in northern Europe. Biogeochem 89(1):121-137. doi:10.1007/s10533-007-9121-3

Innes JL (1993) Forest health: Its assessment and status. Oxon CAB International

Innes J, Whittaker RJ (1993) Relationships between the crown condition of Sitka and Norway spruce and the environment in Great Brittain: an explanatory analysis. J Appl Ecol 30(2): 341-360 
Innes JL, Skelly JM, Schaub M (2001) Ozone and broadleaved species. Eidgenoessische Forschungsanstalt WSL, Birmensdorf, Haupt Verlag, Bern, Stuttgart, Wien

Iost S, Rautio P, Lindroos A-J (2012) Spatio-temporal trends in soil solution $\mathrm{Bc} / \mathrm{Al}$ and $\mathrm{N}$ in relation to critical limits in European forest soils. Water Air Soil Pollut 223(4):14671479. doi:10.1007/s11270-011-0958-7

IPCC (2001) Climate change: the scientific basis. Contribution of WG I to the Third Assessment Report of the Intergovernmental Panel on Climate Change. Cambridge University Press

IPCC (2007) Climate Change 2007: The Physical Science Basis. Contribution of Working Group I to the Fourth Assessment Report of the Intergovernmental Panel on Climate Change. Cambridge University Press, Cambridge, United Kingdom and New York, NY, USA

Jolly WM, Dobbertin M, Zimmermann NE, Reichstein M (2005) Divergent vegetation growth responses to the 2003 heat wave in the Swiss Alps. Geophys Res Lett 32(22), L18409. doi:10. 1029/2005GL023252

Kandler O (1988) Epidemiologische Bewertung der Waldscahedenserhebungen 1983 bis 1987 in der Bundesrepublik Deutschland. Allgem Forst- und Jagdzeitung 159:179-194

Kandler O (1992) The German forest decline situation: A complex disease or a complex of diseases? In: Manion PD, Lachance D (eds) Forest decline concepts. APS Press. The American Phytopathological Society, St. Paul, Minnesota, pp 59-84

Kandler O, Innes JL (1995) Air pollution and forest decline in central Europe. Environ Pollut 90(2):171-180. doi:10.1016/ 0269-7491(95)00006-D

Kärenlampi L, Skärby L (1996) Critical levels for ozone in Europe: testing and finalizing the concepts. Univ. of Kuopio, Dept. of Ecology and Environmental Science, Kuopio, Finland

Karlsson PE, Örlander G, Uddling J, Peterson M, Longvaal O, Greenfelt P (2003) Verifying the impact of tropospheric ozone on mature Norway spruce treesda statistical analysis of stem growth of Norway spruce in relation to clmate change and ozone exposure. In: Karlsson PE, Selldén G, Pleijel H (eds) Establishing Ozone Critical Level II. UN/ECE Workshop Report, IVL report B 1523. IVL Swedish Environmental Research Institute, Gothenburg, Sweden, pp 329-335.

Karlsson PE, Medin EL, Ottosson S, Selldén G, Wallin G, Pleijel H, Skärby L (2004a) A cumulative ozone uptake-response relationship for the growth of Norway spruce saplings. Environ Pollut 128(3):405-417. doi:10.1016/j.envpol.2003. 09.008

Karlsson PE, Uddling J, Braun S, Broadmeadow M, Elvira S, Gimeno BS, Le Thiec D, Oksanen E, Vandermeiren K, Wilkinson M, Emberson L (2004b) New critical levels for ozone effects on young trees based on AOT40 and simulated cumulative leaf uptake of ozone. Atmos Environ 38:2283-2294

Karlsson PE, Örlander G, Langvall O, Uddling J, Hjorte U, Wiklander K, Areskoug B, Grennfelt P (2006) Negative impact of ozone on the stem basal area increment of mature Norway spruce in south Sweden. For Ecol Manag 232(1-3): 146-151. doi:10.1016/j.foreco.2006.05.059

Karlsson PE, Braun S, Broadmeadow M, Elvira S, Emberson L, Gimeno BS, Le Thiec D, Novak K, Oksanen E, Schaub M,
Uddling J, Wilkinson M (2007) Risk assessments for forest trees: the performance of the ozone flux versus the AOT concepts. Environ Pollut 146:608-616

Karnosky DF, Zak DR, Pregitzer KS, Awmack CS, Bockheim JG, Dickson RE, Hendrey GR, Host GE, King JS, Kopper BJ, Kruger EL, Kubiske ME, Lindroth RL, Mattson WJ, Mcdonald EP, Noormets A, Oksanen E, Parsons WFJ, Percy KE, Podila GK, Riemenschneider DE, Sharma P, Thakur R, Sôber A, Sôber J, Jones WS, Anttonen S, Vapaavuori E, Mankovska B, Heilman W, Isebrands JG (2003) Tropospheric $\mathrm{O}_{3}$ moderates responses of temperate hardwood forests to elevated $\mathrm{CO}_{2}$ : a synthesis of molecular to ecosystem results from the Aspen FACE project. Funct Ecol 17(3):289-304. doi:10.1046/j.1365-2435.2003.00733.x

Karnosky DF, Skelly JM, Percy KE, Chappelka AH (2007a) Perspectives regarding 50 years of research on effects of tropospheric ozone air pollution on US forests. Environ Pollut 147(3):489-506. doi:10.1016/j.envpol.2006.08.043

Karnosky DF, Werner H, Holopainen T, Percy K, Oksanen T, Oksanen E, Heerdt C, Fabian P, Nagy J, Heilman W, Cox R, Nelson N, Matyssek R (2007b) Free-air exposure systems to scale up ozone research to mature trees. Plant Biol 9(2): 181-190

Kitao M, Winkler JB, Löw M, Nunn AJ, Kuptz D, Häberle K-H, Reiter IM, Matyssek R (2012) How closely does stem growth of adult beech (Fagus sylvatica) relate to net carbon gain under experimentally enhanced ozone stress? Environ Pollut 166:108-115. doi:10.1016/j.envpol.2012.03.014

Kivimäenpää M, Jonsson AM, Stjernquist I, Sellden G, Sutinen S (2004) The use of light and electron microscopy to assess the impact of ozone on Norway spruce needles. Environ Pollut 127:441-453

Klap JM, de Vries W, Erisman JW, van Leeuwen EP (1997) Relationships between forest condition and natural and anthropogenic stress factors on the European scale; pilot study. Report. DLO Winand Staring Centre for Integrated Land, Soil and Water Research, Wageningen, the Netherlands

Klap JM, Oude Voshaar JH, de Vries W, Erisman JW (2000) Effects of environmental stress on forest crown condition in Europe. Part IV: statistical analysis of relationships. Water Air Soil Pollut 119(1-4):387-420. doi:10.1023/ A: 1005157208701

Kolb TE, Matyssek R (2003) Limitations and perspectives about scaling ozone impacts in trees. In: Karnosky DF, Percy KE, Chappelka AH, Simpson C, Pikkarainen J (eds) Air pollution, global change and forests in the new millennium. Developments in Environmental Sciences. Volume 3. Elsevier, pp 141-173. doi:10.1016/S1474-8177(03)03006-7

Kolb TE, Fredericksen TS, Steiner KC, Skelly JM (1997) Issues in scaling tree size and age responses to ozone: a review. Environ Pollut 98:195-208

Kolb TE, Holmberg KM, Wagner MR, Stone JE (1998) Regulation of ponderosa pine foliar physiology and insect resistance mechanisms by basal area treatments. Tree Physiol 18(6):375-381. doi:10.1093/treephys/18.6.375

Körner C (2003) Alpine plant life: Functional plant ecology of high mountain ecosystems, 2nd edn. Springer Verlag, Heidelberg

Kozlowski TT, Pallardy SG (1996) Physiology of woody plants, 2nd edn. Academic Press, San Diego 
Krause G, Kollner B, Grunhage L, Jager H-J, Bender J, Weigel HJ, Ashmore M, Emberson L, Karlsson P-E, Pleijel H (2005) New Directions: Discussion of "A new generation of ozone critical levels for the protection of vegetation in Europe" by Ashmore et al. Atmos Environ 39:5213-5217

Krupa SV, Legge AH (2000) Passive sampling of ambient, gaseous air pollutants: an assessment from an ecological perspective. Environ Pollut 107(1):31-45. doi:10.1016/S02697491(99)00154-2

Lammel R (1984) Endgültige Ergebnisse und bundesweite Kartierung der Waldschadenserhebung 1983. AFZ-Der Wald 39:340-344

Landmann G (1993) Role of climate, stand dynamics and past management in forest declines: A review of ten years of field ecology in France. In: Huettl RF, Mueller-Dombois D (eds) Forest decline in the Atlantic and pacific region. SpringerVerlag, Berlin, pp 30-39

Landmann G (1995) Forest decline and air pollution effects in the French mountains: A synthesis. In: Landmann G, Bonneau M (eds) Forest decline and atmospheric deposition effects in the French mountains. SpringerVerlag, Berlin

Landmann G, Bonneau M (eds) (1995) Forest decline and atmospheric deposition effects in the French mountains. SpringerVerlag, Berlin

Lange H, Solberg S, Clarke N (2006) Aluminum dynamics in forest soil waters in Norway. Sci Tot Environ 367(2-3):942957. doi:10.1016/j.scitotenv.2006.01.033

Laubhann D, Sterba H, Reinds GJ, de Vries W (2009) The impact of atmospheric deposition and climate on forest growth in European monitoring plots: an individual tree growth model. For Ecol Manag 258(8):1751-1761. doi:10.1016/j.foreco. 2008.09.050

Lawrence GB, Lapenis A, Berggren D, Aparin BF, Smith KT, Shortle WC, Bailey SW, Varlyguin DL, Babikov B (2005) Climate dependency of tree growth suppressed by acid deposition effects on soils in northwest Russia. Environ Sci Technol 39(7):2004-2010. doi:10.1021/es048759o

LeBauer DS, Treseder KK (2008) Nitrogen limitation of net primary productivity in terrestrial ecosystems is globally distributed. Ecology 89(2):371-379. doi:10.1890/06-2057.1

Lebourgeois F (2007) Climatic signal in annual growth variation of silver fir (Abies alba Mill.) and spruce (Picea abies Karst.) from the French Permanent Plot Network (RENECOFOR). Ann For Sci 64(3):333-343. doi:10.1051/forest:2007010

Lebourgeois F, Bréda N, Ulrich E, Granier A (2005) Climate-treegrowth relationships of European beech (Fagus sylvatica L.) in the French Permanent Plot Network (RENECOFOR). Trees-Struct Funct 19(4):385-401. doi:10.1007/s00468004-0397-9

Leeters EEJM, de Vries W, Hoogland T, van Delft B, Wieggers R, Brus DJ, Olsthoorn AFM, van Dobben H, Bleeker A (2007) What happened to our forests in the last decades? Results of more than ten years of forest ecosystem monitoring in the Netherlands. Report 1528. Alterra, Wageningen

Leuzinger S, Zotz G, Asshoff R, Körner C (2005) Responses of deciduous forest trees to severe drought in Central Europe. Tree Physiol 25(6):641-650. doi:10.1093/treephys/25.6.641

Lien L, Raddum GG, Fjellheim A, Henriksen A (1996) A critical limit for acid neutralizing capacity in Norwegian surface waters, based on new analyses of fish and invertebrate responses. Sci Tot Environ 177(1-3):173-193. doi:10.1016/ 0048-9697(95)04894-4

Liu L, Greaver TL (2009) A review of nitrogen enrichment effects on three biogenic GHGs: the $\mathrm{CO} 2$ sink may be largely offset by stimulated $\mathrm{N} 2 \mathrm{O}$ and $\mathrm{CH} 4$ emission. Ecol Lett 12(10):1103-1117. doi:10.1111/j.1461-0248. 2009.01351.x

Livsey S, Barklund P (1993) Lophodermium piceae and Rhizosphaera kalkhoffii in fallen needles of Norway spruce (Picea abies). Eur J For Pathol 22(4):204-216. doi:10.1111/j. 1439-0329.1992.tb00785.x

Lloret F, Peñuelas J, Estiarte M (2005) Effects of vegetation canopy and climate on seedling establishment in Mediterranean shrubland. J Veg Sci 16(1):67-76. doi:10. 1111/j.1654-1103.2005.tb02339.x

Lomský B, Materna J, Pfanz H (2002) $\mathrm{SO}_{2}$-pollution and forest decline in the Ore Mountains. Ministry of Agriculture of the Chech Republic. Forestry and Game Management Research Institute, Jiloviste-Strnady

Lorenz M (1995) International co-operative programme on assessment and monitoring of air pollution effects on forests - ICP forests. Water Air Soil Pollut 85(3):1221-1226. doi:10.1007/ BF00477148

Lorenz M, Becher G (2012) Forest Condition in Europe, 2012 Technical Report of ICP Forests. ICP Forests, Hamburg

Lorenz M, Augustin S, Becher G, Förster M, Müller-Edzards C (1998) Forest condition in Europe. Results of the 1997 crown condition survey. 1998 technical report. UN/ECE-EC, Geneva, Brussels

Lorenz M, Mues V, Becher G, Müller-Edzards C, Luyssaert S, Raitio H, Fürst A, Langouche D (2003) Forest condition in Europe. Results of the 2002 large-scale survey. Technical Report. UNECE/EC, Geneva and Brussels

Lorenz M, Becher G, Mues V, Fischer R, Becker R, Calatayud V, Dise N, Krause GHM, Sanz M, Ulrich E (2005) Forest Condition in Europe, Technical Report. UNECE/EC, Geneva

Lüscher D (1989) Die Blütenbildung bei Bäumen und ihre auswirkung auf die Struktur der Krone: III. Die Fichte (Picea abies [L.] Karst.). Schweiz Z Forstwes 140(9):813822

MacDonald JA, Dise NB, Matzner E, Armbruster M, Gundersen P, Forsius M (2002) Nitrogen input together with ecosystem nitrogen enrichment predict nitrate leaching from European forests. Glob Chang Biol 8(10):1028-1033. doi:10.1046/j. 1365-2486.2002.00532.x

Magill AH, Aber JD, Hendricks JJ, Bowden RD, Melillo JM, Steudler PA (1997) Biogeochemical response of forest ecosystems to simulated chronic nitrogen deposition. Ecol Appl 7(2):402-415. doi:10.1890/1051-0761(1997) 007[0402:BROFET]2.0.CO;2

Magill AH, Aber JD, Currie W, Nadelhoffer K, Martin M, McDowell WH, Melillo JM, Steudler P (2004) Ecosystem response to 15 years of chronic nitrogen additions at the Harvard Forest LTER, Massachusetts, USA. For Ecol Manag 196(1):7-28

Manes F, Vitale M, Fabi AM, De Santis F, Zona D (2007) Estimates of potential ozone stomatal uptake in mature trees of Quercus ilex in a Mediterranean climate. Environ Exp Bot 59:235-241. doi:10.1016/j.envexpbot.2005.12.001

Manning WJ (2005) Establishing a cause and effect relationship for ambient ozone exposure and tree growth in the forest: 
Progress and an experimental approach. Environ Pollut 137(3):443-454. doi:10.1016/j.envpol.2005.01.031

Manning WJ, Krupa SV, Bergweiler CJ, Nelson KI (1996) Ambient ozone $\left(\mathrm{O}_{3}\right)$ in three class I wilderness areas in the northeastern USA: measurements with Ogawa passive samplers. Environ Pollut 91(3):399-403. doi:10.1016/02697491(95)00075-5

Marschner H (1990) Mineral nutrition of higher plants. Academic Press, London, San Diego, New York, Boston, Sydney, Tokyo

Martínez-Vilalta J, Piñol J (2002) Drought-induced mortality and hydraulic architecture in pine populations of the NE Iberian Peninsula. For Ecol Manag 161(1-3):247-256. doi:10.1016/ S0378-1127(01)00495-9

Mather RA (1994) Forest condition in Great Britain. 1989 to 1992. University of Oxford, Oxford

Mather R, Freer-Smith P, Savill P (1995) Analysis of the changes in forest condition in Britain 1989 to 1992. In: Forestry Commission Bulletin 116. HMSO, London, UK

Matyssek R, Sandermann H Jr (2003) Impact of ozone on trees: An ecophysiological perspective. In: Esser K, Lüttge U, Beyschlag W, Hellwig F (eds) Progress in botany, vol 64. Springer-Verlag, Heidelberg, pp 349-404

Matyssek R, Günthardt-Goerg MS, Maurer S, Keller T (1995) Nighttime exposure to ozone reduces whole-plant production in Betula-pendula. Tree Physiol 15(3):159-165. doi:10.1093/ treephys/15.3.159

Matyssek R, Wieser G, Nunn AJ, Kozovits AR, Reiter IM, Heerdt C, Winkler JB, Baumgarten M, Haberle KH, Grams TEE, Werner H, Fabian P, Havranek WM (2004) Comparison between AOT40 and ozone uptake in forest trees of different species, age and site conditions. Atmos Environ 38:22712281

Matyssek R, Bahnweg G, Ceulemans R, Fabian P, Grill D, Hanke DE, Kraigher H, O $\beta$ wald W, Rennenberg H, Sandermann H, Tausz M, Wieser G (2007a) Synopsis of the CASIROZ case study: carbon sink strength of Fagus sylvatica L. in a changing environment: experimental risk assessment of mitigation by chronic ozone impact. Plant Biol 9(2):163-180. doi:10. 1055/s-2007-964883

Matyssek R, Bytnerowicz A, Karlsson P-E, Paoletti E, Sanz M, Schaub M, Wieser G (2007b) Promoting the $\mathrm{O}_{3}$ flux concept for European forest trees. Environ Pollut 146(3):587-607. doi:10.1016/j.envpol.2006.11.011

Matyssek R, Karnosky DF, Wieser G, Percy K, Oksanen E, Grams TEE, Kubiske M, Hanke D, Pretzsch H (2010a) Advances in understanding ozone impact on forest trees: messages from novel phytotron and free-air fumigation studies. Environ Pollut 158(6):1990-2006. doi:10.1016/j.envpol.2009.11.033

Matyssek R, Wieser G, Ceulemans R, Rennenberg H, Pretzsch H, Haberer K, Löw M, Nunn AJ, Werner H, Wipfler P, Oßwald W, Nikolova P, Hanke DE, Kraigher H, Tausz M, Bahnweg G, Kitao M, Dieler J, Sandermann H, Herbinger K, Grebenc T, Blumenröther M, Deckmyn G, Grams TEE, Heerdt C, Leuchner M, Fabian P, Häberle K-H (2010b) Enhanced ozone strongly reduces carbon sink strength of adult beech (Fagus sylvatica) - Resume from the free-air fumigation study at Kranzberg Forest. Environ Pollut 158(8):25272532. doi:10.1016/j.envpol.2010.05.009

Matzner E, Murach D (1995) Soil changes induced by air pollutant deposition and their implication for forests in central Europe. Water Air Soil Pollut 85(1):63-76. doi: 10.1007/BF00483689

McDowell N, Pockman WT, Allen CD, Breshears DD, Cobb N, Kolb T, Plaut J, Sperry J, West A, Williams DG, Yepez EA (2008) Mechanisms of plant survival and mortality during drought: why do some plants survive while others succumb to drought? New Phytol 178(4):719-739. doi:10.1111/j. 1469-8137.2008.02436.x

McLaughlin SB, Wimmer R (1999) Tansley Review No. 104, Calcium physiology and terrestrial ecosystem processes. New Phytol 142(3):373-417. doi:10.1046/j.1469-8137. 1999.00420.x

Mengel K (1991) Ernährung und Stoffwechsel der Pflanze. 7th revised edition. Jena

Millán MM, Mantilla E, Salvador R, Carratalá A, Sanz MJ, Alonso L, Gangoiti G, Navazo M (2000) Ozone cycles in the Western Mediterranean Basin: interpretation of monitoring data in complex coastal terrain. J Appl Meteorol 39:487508

Mills G, Pleijel H, Büker P, Braun S, Emberson L, Harmens H, Hayes F, Simpson D, Grünhage L, Karlsson P-E, Danielsson H, Bermejo V, Fernandez IG (2010) Chapter 3 of the LRTAP Convention Manual of Methodologies for Modelling and Mapping Effects of Air Pollution.

Mol WJA, van Hooydonk PR, de LeeuwFAAM (2010) The state of the air quality in 2008 and the European exchange of monitoring information in 2009.

Monks P, Richard A, Dentener F, Jonson J, Lindskog A, Roemer M, Schuepbach E, Friedli T, Solberg S (2003) Tropospheric ozone and precursors, trends budgets and policy, TROTREP synthesis and integration report.

Müller-Edzards C, de Vries W, Erisman JW (1997) Ten years of monitoring forest condition in Europe - studies on temporal development, spatial distribution and impacts of natural and anthropogenic stress factors. Technical background report. EC-UN/ECE, Geneva, Brussels

Musselman RC, Hale BA (1997) Methods for controlled and field ozone exposures of forest tree species in North America. In: Sandermann H, Wellburn AR, Heath RL (eds) Ecological Studies; Forest decline and ozone: A comparison of controlled chamber and field experiments.

Muzika RM, Guyette RP, Zielonka T, Liebhold AM (2004) The influence of $\mathrm{O}_{3}, \mathrm{NO}_{2}$ and $\mathrm{SO}_{2}$ on growth of Picea abies and Fagus sylvatica in the Carpathian Mountains. Environ Pollut 130(1):65-71. doi:10.1016/j.envpol.2003.10.021

Nadelhoffer KJ, Emmett BA, Gundersen P, Kjønaas OJ, Koopmans CJ, Schleppi P, Tietema A, Wright RF (1999) Nitrogen deposition makes a minor contribution to carbon sequestration in temperate forests. Nature 398:145-148. doi: 10.1038/18205

Nelleman C, Frogner T (1994) Spatial patterns of spruce defoliation seen in relation to acid deposition, critical loads and natural growth conditions in Norway. Ambio 23(4-5):255259

Novak K, Skelly JM, Schaub M, Kräuchi N, Hug C, Landolt W, Bleuler P (2003) Ozone air pollution and foliar injury development on native plants of Switzerland. Environ Pollut 125(1):41-52. doi:10.1016/S0269-7491(03)00085-X

Novak K, Schaub M, Fuhrer J, Skelly JM, Hug C, Landolt W, Bleuler P, Kräuchi N (2005) Seasonal trends in reduced leaf 
gas exchange and ozone-induced foliar injury in three ozone sensitive woody plant species. Environ Pollut 136(1):33-45. doi:10.1016/j.envpol.2004.12.018

Novak K, Schaub M, Fuhrer J, Skelly JM, Frey B, Kräuchi N (2008) Ozone effects on visible foliar injury and growth of Fagus sylvatica and Viburnum lantana seedlings grown in monoculture or in mixture. Environ Exp Bot 62(3):212-220. doi:10.1016/j.envexpbot.2007.08.008

Nunn AJ, Kozovits AR, Reiter IM, Heerdt C, Leuchner M, Lütz C, Liu X, Löw M, Winkler JB, Grams TEE, Häberle K-H, Werner H, Fabian P, Rennenberg H, Matyssek R (2005) Comparison of ozone uptake and sensitivity between a phytotron study with young beech and a field experiment with adult beech (Fagus sylvatica). Environ Pollut 137:494506

Nunn AJ, Wieser G, Reiter IM, Haberle K-H, Grote R, Havranek WM, Matyssek R (2006) Testing the unifying theory of ozone sensitivity with mature trees of Fagus sylvatica and Picea abies. Tree Physiol 26:1391-1403

Oberdorfer E (1979) Pflanzensoziologische Exkursionsflora. 4. Aufl. Ulmer, Stuttgart

Økland T, Bakkestuen V, Økland RH, Eilertsen O (2004) Changes in forest understorey vegetation in Norway related to long-term soil acidification and climatic change. J Veg Sci 15(4):437-448. doi:10.1111/j.16541103.2004.tb02282.x

Ollinger SV, Aber JD, Reich PB (1997) Simulating ozone effects on forest productivity: Interactions among leaf-, canopy-, and stand-level processes. Ecol Appl 7(4):1237-1251. doi:10. 1890/1051-0761(1997)007[1237:SOEOFP]2.0.CO;2

Owens JN, Blake MD (1985) Forest tree seed production: a review of the literature and recommendations for future research. Can. For. Serv. Inf. Rep. PI-X-53. Petawawa National Forestry Institute, Chalk River, Ont.

Ozolincius R, Stakenas V, Serafinaviciute B (2005) Meteorological factors and air pollution in Lithuanian forests: possible effects on tree condition. Environ Pollut 137(3): 587-595. doi:10.1016/j.envpol.2005.01.044

Pallardy SG (2008) Physiology of woody plants. Academic Press, San Diego, California, USA

Paoletti E (2006) Impact of ozone on Mediterranean forests: a review. Environ Pollut 144(2):463-474. doi:10.1016/j. envpol.2005.12.051

Percy KE, Ferretti M (2004) Air pollution and forest health: toward new monitoring concepts. Environ Pollut 130(1): 113-126. doi:10.1016/j.envpol.2003.10.034

Percy KE, Legge AH, Krupa SV (2003) Tropospheric ozone: A continuing threat to global forests? In: Karnosky DF, Percy KE, Chappelka AH, Simpson C, Pikkarainen J (eds) Air Pollution, Global Change and Forests in the New Millenium. doi:10.1016/S1474-8177(03)03004-3

Pregitzer KS, Burton AJ, Zak DR, Talhelm AF (2008) Simulated chronic nitrogen deposition increases carbon storage in Northern Temperate forests. Glob Chang Biol 14(1):142153. doi:10.1111/j.1365-2486.2007.01465.x

Pretzsch H, Dieler J, Matyssek R, Wipfler P (2010) Tree and stand growth of mature Norway spruce and European beech under long-term ozone fumigation. Environ Pollut 158(4):10611070. doi:10.1016/j.envpol.2009.07.035

Rautjärvi H, Ukonmaanaho L, Raitio H (2002) Forest condition monitoring in Finland. National report 2001
Rebetez M, Dobbertin M (2004) Climate change may already threaten Scots pine stands in the Swiss Alps. Theor Appl Climatol 79(1-2):1-9. doi:10.1007/S00704-004-0058-3

Rebetez M, Reinhard M (2008) Monthly air temperature trends in Switzerland 1901-2000 and 1975-2004. Theor Appl Climatol 91(1-4):27-34. doi:10.1007/S00704-007-0296-2

Reich PB (1987) Quantifying plant response to ozone: a unifying theory. Tree Physiol 3(1):63-91. doi:10.1093/treephys/3.1. 63

Ringvall A, Petersson H, Ståhl G, Lämås T (2005) Surveyor consistency in presence/absence sampling for monitoring vegetation in a boreal forest. For Ecol Manag 212:109-117. doi:10.1016/j.foreco.2005.03.002

Roberts TM, Skeffington RA, Blank LW (1989) Causes of type 1 spruce decline in Europe. Forestry 62(3):179-222. doi:10. 1093/forestry/62.3.179-a

Roelofs JGM, Kempers AJ, Houdijk ALFM, Jansen J (1985) The effect of airborne ammonium sulphate on Pinus nigra var. maritima in the Netherlands. Plant Soil 84(1):45-56. doi:10. 1007/BF02197866

Samuelson L, Kelly JM (2001) Scaling ozone effects from seedlings to forest trees. New Phytol 149(1):21-41. doi:10.1046/ j.1469-8137.2001.00007.x

Sandermann HJ (1996) Ozone and plant health. Annu Rev Phytopathol 34:347-366. doi:10.1146/annurev.phyto.34.1.347

Sandermann H, Wellburn AR, Health RL (1997) Forest decline and ozone: synopsis. In: Forest decline and ozone: a comparison of controlled chamber and field experiments. Ecological Studies Series 127. SpringerVerlag, Berlin, pp 369-377

Sanz MJ, Krause G (2001) State of the art of passive sampling in the Pan European Program for Forest. In: Brown RH, Hafkensheod TL, Saunders KJ, Borowiak A, de Saeger E (eds) International Conference Measuring Air Pollutants by Diffusive Sampling, Montpellier, France, 26-28 September 2001. European Commission. Joint Research Centre, pp 10-15

Sanz MJ, Millán MM (1998) The dynamics of aged airmasses and ozone in the western Mediterranean: relevance to forest ecosystems. Chemosphere 36(4-5):1089-1094. doi:10.1016/ S0045-6535(97)10177-1

Sanz MJ, Calatayud V, Calvo E (2000) Spatial pattern of ozone injury in Aleppo pine related to air pollution dynamics in a coastal-mountain region of eastern Spain. Environ Pollut 108(2):239-247. doi:10.1016/S0269-7491(99)00182-7

Sanz MJ, Sanz F, Sánchez-Peña G (2001) Spatial and annual temporal distribution of ozone concentrations in the Madrid basin using passive samplers. Sci World 1:785-795. doi:10. 1100/tsw.2001.316

Sanz MJ, Calatayud V, Sánchez-Peña G (2007) Measures of ozone concentrations using passive sampling in forests of South Western Europe. Environ Pollut 145(3):620-628. doi:10. 1016/j.envpol.2006.02.031

Schär C, Vidale P, Lüthi D, Frei C, Häberli C, Liniger M, Appenzeller C (2004) The role of increasing temperature variability in European summer heatwaves. Nature 427: 332-336. doi:10.1038/nature02300

Schaub M, Sanz MJ (2005) Ozone visible injury assessment across Europe. Int For Rev 7(5):284

Schaub M, Jakob P, Bernhard L, Innes JL, Skelly JM, Kräuchi N (2002) Ozone injury database. www.ozone.wsl.ch. Swiss Federal Research Institute WSL. 
Schaub M, Emberson L, Büker P, Kräuchi N (2007) Preliminary results of modeled ozone uptake for Fagus sylvatica L. trees at selected EU/UN-ECE intensive monitoring plots. Environ Pollut 145(3):636-643. doi:10.1016/j.envpol.2006.02.029

Schaub M, Skelly JM, Zhang JW, Ferdinand JA, Savage JE, Stevenson RE, Davis DD, Steiner KC (2005) Physiological and foliar symptom response in the crowns of Prunus serotina, Fraxinus americana and Acer rubrum canopy trees to ambient ozone under field conditions. Environ Pollut 133: 553-567

Schöpfer W, Hradetzky J (1984) Der indisienbeweis: Luftverschmutzung maßgebliche Ursache der Walderkrankung [Circumstantial evidence: air pollution is the determinative factor causing forest decline]. Forstw $\mathrm{Cbl}$ 103(1):231-247. doi:10.1007/BF02744235

Schöpp W, Posch M, Mylona S, Johansson M (2003) Long-term development of acid deposition (1880-2030) in sensitive freshwater regions in Europe. Hydrol Earth Syst Sci 7(4): 436-446. doi:10.5194/hess-7-436-2003

Schulze E-D (1989) Air pollution and forest decline in a spruce (picea abies) forest. Science 244:776-783

Schütt P, Blaschke H, Hoque E, Koch W, Lang KJ, Schuck HJ (1983) Erste Ergebnisse einer botanischen Inventur des 'Fichtensterbens'. Forstw Cbl 102(1):177-186. doi:10. 1007/BF02741848

Schweingruber FH (1996) Tree rings and environment: Dendroecology. Paul Haupt, Bern

Seidling W (2004) Crown condition within integrated evaluations of level II monitoring data at the German level. Eur J For Res 123(1):63-74. doi:10.1007/s10342-004-0014-x

Seidling W (2007) Signals of summer drought in crown condition data from the German Level I network. Eur J For Res 126(4): 529-544. doi:10.1007/S10342-007-0174-6

Seidling W, Fischer R (2008) Deviances from expected Ellenberg indicator values for nitrogen are related to $\mathrm{N}$ throughfall deposition in forests. Ecol Indic 8(5):639-646. doi:10.1016/ j.ecolind.2007.09.004

Seidling W, Fischer R, Granke O (2008) Relationships between forest floor vegetation on ICP Forests monitoring plots in Europe and basic variables in soil and nitrogen deposition. Int J Environ Stud 65(3):311-322. doi:10.1080/ 00207230701862538

Shaw JD, Steed BE, DeBlander LT (2005) Forest inventory and analysis (FIA) annual inventory answers the question: what is happening to pinyon-juniper woodlands? J For 103(6):280 285

Simpson D, Tuovinen J-P, Emberson L, Ashmore M (2003) Characteristics of an ozone deposition module II. Sensitivity analysis. Water Air Soil Pollut 143(1-4):123137. doi:10.1023/A:1022890603066

Simpson D, Ashmore MR, Emberson L, Tuovinen J-P (2007) A comparison of two different approaches for mapping potential ozone damage to vegetation. A model study. Environ Pollut 146(3):715-725. doi:10.1016/j.envpol.2006.04.013

Sitch S, Cox PM, Collins WJ, Huntingford C (2007) Indirect radiative forcing of climate change through ozone effects on the land-carbon sink. Nature 448(7155):791-794. doi: 10.1038 /nature 06059

Skelly JM, Innes JL (1994) Waldsterben in the forests of central Europe and eastern North America: fantasy or reality? Plant Dis 78(11):1021-1032. doi:10.1094/PD-78-1021
Skelly JM, Innes JL, Savage JE, Snyder KR, Vanderheyden D, Zhang J, Sanz MJ (1999) Observation and confirmation of foliar ozone symptoms of native plant species of Switzerland and southern Spain. Water Air Soil Pollut 116(1-2):227-234. doi:10.1023/A:1005275431399

Solberg S (2004) Summer drought: a driver for crown condition and mortality of Norway spruce in Norway. For Pathol 34(2): 93-104. doi:10.1111/j.1439-0329.2004.00351.x

Solberg S, Tørseth K (1997) Crown condition of Norway spruce in relation to sulphur and nitrogen deposition and soil properties in Southeast Norway. Environ Pollut 96(1):19-27. doi:10. 1016/S0269-7491(97)00010-9

Solberg S, Kvindesland S, Aamlid D, Venn K (2002) Crown condition and needle chemistry of Norway spruce in relation to critical loads of acidity in South-East Norway. Water Air Soil Pollut 140(1-4):157-171. doi:10.1023/ A: 1020131307937

Solberg S, Andreassen K, Clarke N, Torseth K, Tveito OE, Strand GH, Tomter S (2004) The possible influence of nitrogen and acid deposition on forest growth in Norway. For Ecol Manag 192(2-3):241-249. doi:10.1016/j.foreco.2004.01.036

Solberg S, Dobbertin M, Reinds GJ, Lange H, Andreassen K, Fernandez PG, Hildingsson A, de Vries W (2009) Analyses of the impact of changes in atmospheric deposition and climate on forest growth in European monitoring plots: a stand growth approach. For Ecol Manag 258(8):17351750. doi:10.1016/j.foreco.2008.09.057

Spiecker H (1986) Das Wachstum der Tannen und Fichten auf Plenterwald-Versuchsflächen des Schwarzwaldes in der Zeit von 1950 bis 1984. Allgem Forst- und Jagdzeitung 157:152164

Spiecker H, Mielikäinen K, Kölh M, Skovsgaard JP (eds) (1996) Growth trends in European forests. Studies from 12 Countries. Research Report 5. Springer-Verlag, Berlin, Heidelberg

Staffelbach T, Neftel A, Blatter A, Gut A, Fahrni M, Stähelin J, Prévôt A, Hering A, Lehning M, Neininger B, Bäumle M, Kok GL, Dommen J, Hutterli M, Anklin M (1997a) Photochemical oxidant formation over southern Switzerland: 1. Results from summer 1994. J Geophys Res 102(D19):23345-23362. doi:10.1029/97JD00933

Staffelbach T, Neftel A, Horowitz LW (1997b) Photochemical oxidant formation over southern Switzerland: 2. Model results. J Geophys Res 102(D19):23363-23373. doi:10.1029/ 97JD00932

Stefan K, Fürst A, Hacker R, Bartels U (1997) Forest Foliar Condition in Europe. Results of large-scale foliar chemistry surveys (survey 1995 and data from previous years). EC-UN/ ECE, Brussels, Geneva

Stierlin H-R, Brandli U-B, Herold A, Zinggeler J (1994) Swiss National Forest Inventory: Guide to the field surveys of the Inventory of 1993-1995.

Sverdrup H, Warfvinge P (1993) The effect of soil acidification on the growth of trees, grass and herbs as expressed by the $(\mathrm{Ca}+$ $\mathrm{Mg}+\mathrm{K}) / \mathrm{Al}$ ratio. Reports in Ecology and Environmental Engineering 1993:. Lund University, Department of Chemical Engineering II,

Takemoto BK, Bytnerowicz A, Fenn ME (2001) Current and future effects of ozone and atmospheric nitrogen deposition on California's mixed conifer forests. For Ecol Manag 144(1-3):159-173. doi:10.1016/S0378-1127(00)00368-6 
Thimonier A, Dupouey JL, Timbal J (1992) Floristic changes in the herb-layer vegetation of a deciduous forest in the Lorraine Plain under the influence of atmospheric deposition. For Ecol Manag 55(1-4):149-167. doi:10.1016/0378-1127(92) 90098-T

Thomas FM, Blank R, Hartmann G (2002) Abiotic and biotic factors and their interactions as causes of oak decline in Central Europe. For Pathol 32(4-5):277-307. doi:10.1046/j. 1439-0329.2002.00291.x

Tyler G (1987) Probable effects of soil acidification and nitrogen deposition on the floristic composition of oak (Quercus robur L.) forest. Flora 179:165-170

Ulrich B (1984) Effects of air pollution on forest ecosystems and waters: the principles demonstrated at a case study in Central Europe. Atmos Environ 18(3):621-628. doi:10.1016/00046981(84)90182-3

Ulrich B, Pankrath J (1983) Effects of accumulation of air pollutants on forest ecosystems. D. Reidel Publ. Co., Dordrecht, The Netherlands

Ulrich B, Mayer R, Khanna PK (1980) Chemical changes due to acid precipitation in a loess-derived soil in Central Europe. Soil Sci 130(4):193-199

Utriainen J, Holopainen T (2000) Impact of increased springtime $\mathrm{O}_{3}$ exposure on Scots pine (Pinus sylvestris) seedlings in central Finland. Environ Pollut 109(3):479-487. doi:10. 1016/S0269-7491(00)00051-8

Van Breemen N, Driscoll CT, Mulder J (1984) Acidic deposition and internal proton sources in acidification of soils and waters. Nature 307:599-604. doi:10.1038/307599a0

Van der Salm C, de Vries W, Reinds GJ, Dise NB (2007a) N leaching across European forests: derivation and validation of empirical relationships using data from intensive monitoring plots. Forest Ecol Manage 238:81-91. doi:10.1016/j. foreco.2006.09.092

Van der Salm C, Reinds GJ, de Vries W (2007b) Water balances in intensively monitored forest ecosystems in Europe. Environ Pollut 148(1):201-212. doi:10.1016/j.envpol.2006.10.043

Van Dijk HFG, van der Gaag M, Perik PJM, Roelofs JGM (1992) Nutrient availability in Corsican pine stands in The Netherlands and the occurrence of Sphaeropsis sapinea: a field study. Can J Bot 70(4):870-875. doi:10.1139/b92-111

Van Dobben HF, de Vries W (2010) Relation between forest vegetation, site conditions and atmospheric deposition at regional and European scale. Environ Pollut 158(3):921933. doi:10.1016/j.envpol.2009.09.015

Van Dobben HF, ter Braak CJF, Dirkse GM (1999) Undergrowth as a biomonitor for deposition of nitrogen and acidity in pine forest. Forest Ecol Manage 114(1):83-95. doi:10.1016/ S0378-1127(98)00383-1

Van Dobben HF, van Hinsberg A, Schouwenberg EPAG, Jansen MJW, Mol-Dijkstra JP, Wieggers HJJ, Kros J, de Vries W (2006) Simulation of critical loads for nitrogen for terrestrial plant communities in the Netherlands. Ecosystems 9(1):3245. doi:10.1007/s10021-005-0052-3

Van Dobben HF, de Vries W, Reinds GJ, Granke O (2010) In: Fischer $\mathrm{R}$, Lorenz M, Granke $\mathrm{O}$ et al (eds) Forest Condition in Europe, 2010. Technical Report of ICP Forests. Work Report of the Institute for World Forestry 2010/1. ICP Forests, Hamburg

Van Mantgem PJ, Stephenson NL, Byrne JC, Daniels LD, Franklin JF, Fule PZ, Harmon ME, Larson AJ, Smith JM, Taylor AH, Veblen TT (2009) Widespread increase of tree mortality rates in the western United States. Science 323: 521-524. doi:10.1126/science. 1165000

Vanmechelen L, Groenemans R, van Ranst E (1997) Forest soil condition in Europe. Results of a large-scale soil survey. ECUN/ECE, Brussels, Geneva

Vapaavuori E, Holopainen JK, Holopainen T, Julkunen-Tiitto R, Kaakinen S, Kasurinen A, Kontunen-Soppela S, Kostiainen K, Oksanen E, Peltonen P, Riikonen J, Tulva I (2009) Rising atmospheric carbon dioxide concentration partially masks the negative effects of elevated ozone in silver birch (Betula pendula Roth). Ambio 38(8):418-424

Vingarzan $\mathrm{R}$ (2004) A review of surface $\mathrm{O}_{3}$ background levels and trends. Atmos Environ 38:3431-3442

Vitousek PM, Howarth RW (1991) Nitrogen limitation on land and in the sea: how can it occur? Biogeochem 13(2):87-115. doi:10.1007/BF00002772

Wamelink GWW, van Dobben HF, Mol-Dijkstra JP, Schouwenberg EPAG, Kros J, de Vries W, Berendse F (2009) Effect of nitrogen deposition reduction on biodiversity and carbon sequestration. For Ecol Manag 258(8):1774 1779. doi:10.1016/j.foreco.2008.10.024

Waring RH (1987) Characteristics of trees predisposed to die. Bioscience 37(8):569-574

Wehrmann J (1961) Die Auswirkung der Trockenheit von 1959 auf die Nährelementversorgung bayerischer Kiefernbestände. Forstw Cbl 80(9-10):272-287. doi:10. 1007/BF01821295

Werner H, Fabian P (2002) Free-air fumigation of mature trees - a novel system for controlled ozone enrichment in grown-up beech and spruce canopies. Environ Sci Pollut R 9:117-121

Whitney RD, Timmer VR (1983) Chlorosis in planted white spruce at Limestone Lake. Inf. Rep. D-X-346. Ontario. Dep. Environ., Can. For. Serv., Sault Ste. Marie, Ont.

Wieser G, Tegischer K, Tausz M, Haberle KH, Grams TEE, Matyssek R (2002) Age effects on Norway spruce (Picea abies) susceptibility to ozone uptake: a novel approach relating stress avoidance to defense. Tree Physiol 22:583-590

Wieser G, Hecke K, Tausz M, Matyssek R (2013) Foliage type specific susceptibility to ozone in Picea abies, Pinus cembra and Larix decidua at treeline: a synthesis. Environ Exp Bot 90:4-11. doi:10.1016/j.envexpbot.2012.09.013

Wild O, Fiore AM, Shindell DT, Doherty RM, Collins WJ, Dentener FJ, Schultz MG, Gong S, MacKenzie IA, Zeng G, Hess P, Duncan BN, Bergmann DJ, Szopa S, Jonson JE, Keating TJ, Zuber A (2012) Modelling future changes in surface ozone: a parameterized approach. Atmos Chem Phys 12:2037-2054. doi:10.5194/acp-12-2037-2012

Wittig VE, Ainsworth EA, Naidu SL, Karnosky DF, Long SP (2009) Quantifying the impact of current and future tropospheric ozone on tree biomass, growth, physiology and biochemistry: a quantitative meta-analysis. Glob Change Biol 15(2):396-424. doi:10.1111/j.1365-2486.2008.01774.x

Worrell R (1983) Damage by the spruce bark beetle in South Norway 1970-80: A survey, and factors affecting its occurrence. Medd Nor Inst Skogforsoeksves 38(6):1-34

Wulff S, Hansson P, Witzell J (2006) The applicability of national forest inventories for estimating forest damage outbreaks - Experiences from a Gremmeniella outbreak in Sweden. Can J For Res 36(10):2605-2613. doi:10. 1139/X06-148 
Zapletal M, Pretel J, Chroust P, Cudlin P, Edwards-Jonasova M, Urban O, Pokorny R, Czerny R, Hunova I (2012) The influence of climate change on stomatal ozone flux to a mountain Norway spruce forest. Environ Pollut 169:267273. doi:10.1016/j.envpol.2012.05.008

Zierl B (2002) Relations between crown condition and ozone and its dependence on environmental factors. Environ Pollut 119(1):55-68. doi:10.1016/S0269-7491(01)00323-2

Zirlewagen D, Raben G, Weise M (2007) Zoning of forest health conditions based on a set of soil, topographic and vegetation parameters. Forest Ecol Manage 248(1-2):43-55. doi:10. 1016/j.foreco.2007.02.038

Zöttl HW, Mies E (1983) Nährelementversorgung und Schadstoffbelastung von Fichtenökosy-stemen im
Südschwarzwald unter Immissionseinfluß. Mitteilungen der Deutschen Botanischen Gesellschaft 38:429-434

Zweifel R, Steppe K, Sterck FJ (2007) Stomatal regulation by microclimate and tree water relations: interpreting ecophysiological field data with a hydraulic plant model. J Exp Bot 58(8):2113-2131. doi:10.1093/jxb/erm050

Zweifel R, Zeugin F, Zimmermann L, Newbery DM (2006) Intraannual radial growth and water relations of trees - implications towards a growth mechanism. J Exp Bot 57(6):14451459. doi:10.1093/jxb/erj125

Zweifel R, Rigling A, Dobbertin M (2009) Species-specific stomatal response of trees to microclimate - a functional link between vegetation dynamics and climate change. J Veg Sci 20(3):442-454. doi:10.1111/j.1654-1103.2009.05701.x 